Gladius XXIII, 2003, pp. 5-60

\title{
CASCOS HALLADOS EN NECRÓPOLIS CELTIBÉRICAS CONSERVADOS EN EL MUSEO ARQUEOLÓGICO NACIONAL DE MADRID
}

\author{
POR
}

MAGDALENA BARRIL VICENTE

\section{RESUMEN - ABSTRACT}

En este trabajo revisaremos los cascos que se conservan en el Museo Arqueológico Nacional, de Madrid, procedentes de las necrópolis celtibéricas de Aguilar de Anguita, en Guadalajara y Alpanseque y Almaluez en Soria; excavadas las dos primeras por D. Enrique de Aguilera y Gamboa, Marqués de Cerralbo y la tercera por D. Blas de Taracena. Estos cascos fueron estudiados y reconstruidos en dibujo, idealmente, por D. Juan Cabré y seguidas sus propuestas en la bibliografía posterior. Los presentamos en su estado actual, que, aunque fragmentario, nos permite comprobar que son cascos que siguen modelos que han sido transformados en el Mediterráneo central. En particular el casco de Aguilar de Anguita sigue un tipo etrusco-itálico, de carrilleras avanzadas que transforma el tipo originario del Mediterráneo oriental; los demás cascos, serían casquetes de forma cónica, con distinta ejecución y decoración, modelo extendido por Europa central y también modificado en la Península Itálica.

This paper analyzes some helmets kept at the Museo Arqueológico Nacional in Madrid. They come from Celtiberian cemeteries at Aguilar de Anguita (province of Guadalajara), Alpanseque and Almaluez (both in Soria). The first two were excavated by D. Enrique de Aguilera y Gamboa, marquis de Cerralbo, and the third by D. Blas de Taracena. The helmets were studied and drawn in ideal reconstruction by D. Juan Cabré, whose designs have been used by later scholars. In this paper we show and draw the helmets in their actual state of preservation, some of them heavily damaged. However, we'll de able to show that the Aguilar de Anguita type follows an etrusco-italic type with peculiar cheekpieces that is in itself a modification of East Mediterranean types. The other helmets are basically conical in shape, with an altogether different handycraft and decoration, and belong to a Centroeuropean model, also modified in the Italian Peninsula.

\section{PALABRAS CLAVE - KEY WORDS}

Armas defensivas. Cascos. Cultura Celtibérica. Necropolis de cremación. Guerrero. Aguilar de Anguita. Alpanseque. Almaluez. Museo Arqueológico Nacional. Madrid. Juan Cabré. Marqués de Cerralbo. Blas de Taracena.

Defensive weapons. Helmets. Celtiberian Iron Age. Cremation cemeteries. Warrior. Aguilar de Anguita. Alpanseque. Almaluez. Museo Arqueológico Nacional. Madrid. Juan Cabré. Marqués de Cerralbo. Blas de Taracena.

En el Museo Arqueológico Nacional, de Madrid, se conservan restos de varios cascos hallados en tumbas de necrópolis celtibéricas que, a pesar de que se conocen desde antiguo, han sido publicados de forma parcial. En algún caso reconstruyéndolos de forma hipotética y en otros simplemente informando de su existencia. Estos cascos proceden, tres, de las exca- 
vaciones del Marqués de Cerralbo en Aguilar de Anguita, Guadalajara y en Alpanseque, Soria y dos de las excavaciones de Taracena en Almaluez, Soria ${ }^{1}$.

En 1887, José Ramón Mélida ${ }^{2}$, realizó un estudio monográfico sobre la Historia del cas$c o$, en el que no menciona ninguna de estas armas defensivas datada en la Antigüedad conservada en el Museo Arqueológico Nacional, ni siquiera procedente del territorio peninsular, lo que si hace para otros períodos históricos. Ello es debido a que, en ese momento, aún no se conocían cascos de momentos prerromanos peninsulares.

Puede decirse que Horace Sandars (1913) es el primer autor que se refiere a ellos, en su síntesis sobre las armas de los Iberos (entendiendo como tal a todos los habitantes de la Península Ibérica en época prerromana). En ella incluye los cascos, como armas defensivas, que describe a partir de citas de los autores clásicos. En el momento de su trabajo conocía ya el casco de Aguilar de Anguita $^{3}$, sobre el que dice no puede aventurar nada hasta que no se restaure y, proporciona una foto del estado del casco en el momento del hallazgo, aunque sin referencia expresa al mismo (1913: 72, lám. X,a). Se trata de una foto que sabemos procede de la obra con la que el Marqués de Cerralbo ganó el Premio Martorell (Aguilera 1911, lám. CXXIII, 1) (Fig. 1). Los cascos de Alpanseque aún no se habían descubierto ya que la necrópolis se excavó unos años después, y lo mismo ocurre con los de Almaluez.

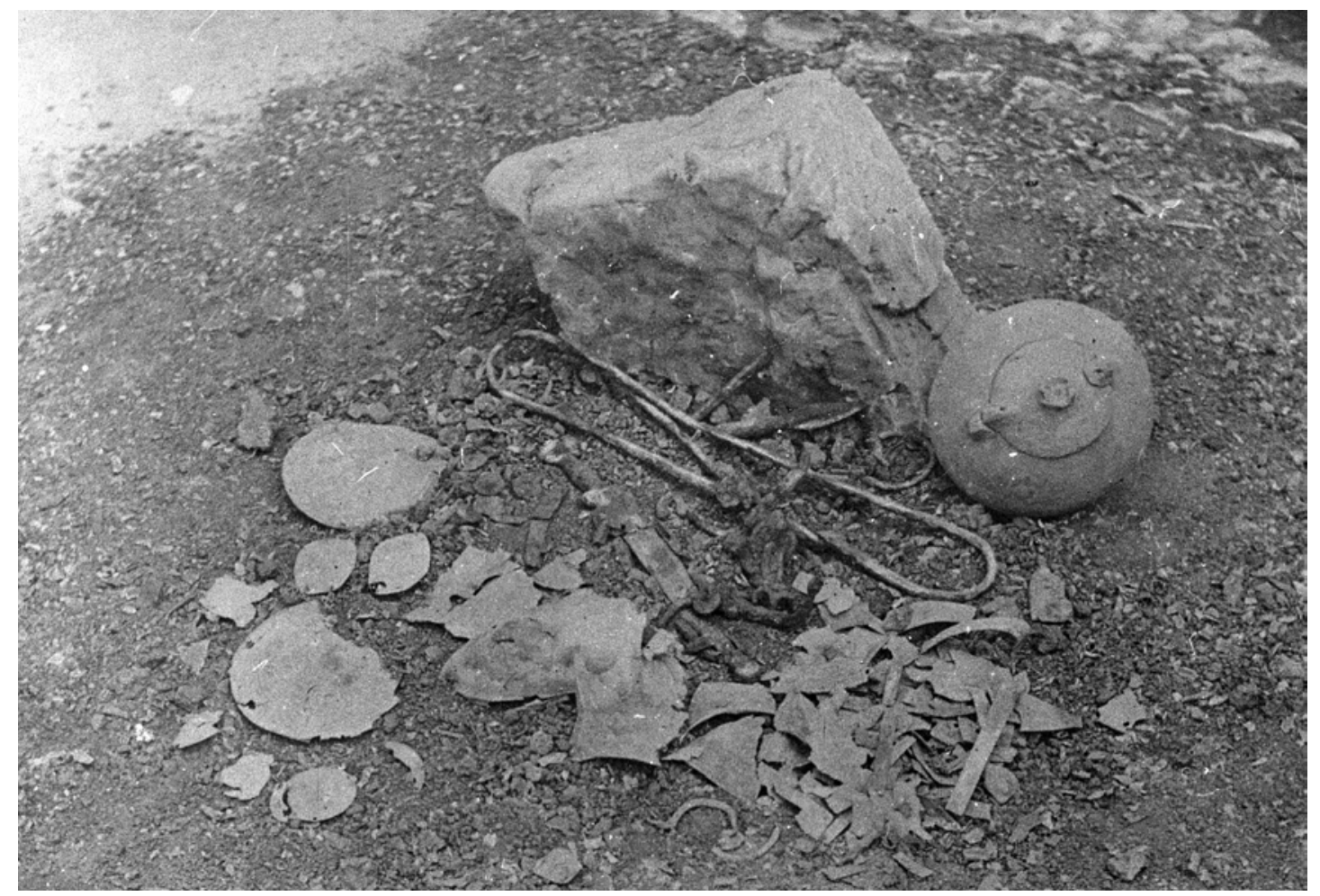

Fig. 1. Casco de Aguilar de Anguita in situ (Aguilera 1911: lám. CXXIII,1).

1 Quedan fuera del ámbito de este estudio los restos que se han interpretado como pertenecientes a cascos hallados en las sepulturas vettonas de La Osera.

2 En aquel momento Facultativo del Cuerpo de Archiveros, Bibliotecarios y Anticuarios destinado en el Museo Arqueológico Nacional.

3 En esa fecha aún no había ingresado en el Museo Arqueológico Nacional. 
Así pues, Sandars sólo pudo documentar restos reales de cascos de bronce similares a los de tipo Montefortino - que no incluimos en este trabajo - y enumera los siguientes tipos de cascos, unos con base material, otros sólo literaria:

a) cascos de bronce o cuero del tipo etrusco o galos, similares a los de Montefortino.

b) «gorras» fabricadas con tendones según la descripción que toma de Diodoro, aunque destacando que se refiere a su fabricación, no a su forma.

c) cascos con penacho o triple penacho, según las descripciones de Estrabón (III, 16, III, 15) de los cascos lusitanos y, Diodoro, el cual denominaba «airain» a los cascos celtibéricos de cobre, adornados con plumas o penachos rojos (Diodoro V, XXXIV).

d) el cabello propio trenzado alrededor de la cabeza y sujeto por una banda, dejando caer dos trenzas a los lados que harían el efecto de yugulares, como aprecia en algunos exvotos.

Revisiones recientes de las citas sobre cascos en las fuentes literarias no modifican sustancialmente el contenido, pero consideramos interesante incluirlas por contener otros matices y remitimos, para su consulta, a la tabla en que Quesada sintetiza el armamento prerromano peninsular según Estrabón y Diodoro Sículo y al resumen historiográfico que realiza el mismo autor (Quesada (1997: 525, fig. 305 y 569-570).

Diodoro $(\mathrm{V}, 33)$ dice «los celtíberos.....en caso de guerra guarnecían su cabeza con un casco de bronce, adornado de gran cresta de color escarlata ..» (según García Huerta 1997: 227), otra versión similar es la de Quesada (1997: 569) «los celtíberos... llevan cascos de bronce (krane kalka) adornados con crestas de color escarlata» y en Diodoro (V, 34) sobre el armamento lusitano se afirma que los cascos (krane) son similares a los celtibéricos.

Estrabón (III, 3,6) describe el armamento de los lusitanos y detalla los cascos «.. la mayor parte llevan corazas de lino y pocos cotas de malla y casco de tres cimeras; los demás se cubren con cascos tejidos de nervios» (García Bellido 1993: 172); descripción que Quesada deja como «kranos de tres penachos» y «kranos de nervios». Más adelante, Estrabón (III, $4,15)$ describe un armamento celtíbero, ligero, dentro del cual no menciona el uso de cascos (Quesada 1997: 569).

A la vista de estas brevísimas descripciones, debemos observar que las referencias son a los cascos de celtíberos y lusitanos, pero no de los íberos, tal como los entendemos hoy día, y que hacen mención al material en que estaban realizados y a su adorno y aspecto, pero no a su forma concreta. Otro aspecto que se deduce de ellas, es que la presencia de cascos metálicos era muy escasa.

El hallazgo de los cascos que a continuación presentaremos y otros, amplió el panorama tipológico de la Península Ibérica, pero sólo conocemos estudios monográficos sobre los cascos de tipo corintio y los tipo Montefortino y similares, mientras que las noticias sobre estos cascos del M.A.N. han sido incluidos en trabajos generales sobre pueblos o armas prerromanas protohistóricas peninsulares, algunos de ellos muy recientes que citaremos conforme necesitemos su referencia concreta.

\section{CASCOS DE LAS EXCAVACIONES DEL MARQUÉS DE CERRALBO}

Enrique de Aguilera y Gamboa, XVII marqués de Cerralbo, sobre el que tanta literatura se ha vertido, excavó numerosas necrópolis celtibéricas en las provincias de Guadalajara, Soria y Zaragoza. En esas tumbas, de ajuares de gran desigualdad en el número y calidad de los objetos hallados, los cascos metálicos eran muy poco frecuentes y por ello su presencia 
se destacaba y han sido ampliamente citados en la bibliografía (Cabré 1940 y 1942: 198, Schüle 1969: 118, Lorrio 1997: 166-167, Quesada 1997: 550-554, Gracia 2003: 207) pero tomando las referencias los últimos del primero.

Como ya se ha indicado son un casco de Aguilar de Anguita, Guadalajara y dos de Alpanseque, Soria. Afortunadamente, disponemos de fotografías de fechas cercanas a su descubrimiento, de ellos y del resto de los elementos que componían el ajuar, e incluso del primer casco aún en la excavación (Aguilera 1911, 1916 y Cabré 1917). Los dibujos que se ofrecieron de ellos y se han venido repitiendo en la bibliografía son reconstrucciones idealizadas, elaboradas a partir de bronces muy fragmentados y/o plegados (Cabré 1940: lám. IV, VI y 1942: fig. 6 y 7 , Schüle 1969: taf. 3, 25, 29). En estas líneas los presentaremos en su estado actual y brevemente esbozaremos algunas ideas que puedan ayudar a su estudio y adscripción.

\section{CAsco de Aguilar de Anguita, Guadalajara}

\section{Contexto}

La necrópolis de 'El Altillo' de Aguilar de Anguita fue excavada por el Marqués de Cerralbo entre 1910 y 1912 (Barril y Salve 1998 y 2000). En ella las tumbas de incineración estaban alineadas en calles y señalizadas muchas de ellas por estelas. Fue una de las primeras necrópolis celtibéricas que se dio a conocer en Europa y también en España (Aguilera 1912, Dechelette 1913: 687) y ello, unido a la calidad y novedad de muchos de los materiales hallados en las tumbas, difundió su nombre en la literatura científica del momento. En una de esas tumbas apareció el casco que estudiamos (Fig. 2), Cerralbo la denominó «sepultura de un régulo celtíbero» y «tumba Déchelette» por la riqueza de su contenido y en honor a que fue hallada en presencia de ese arqueólogo francés al que admiraba (Aguilera 1916: 33-35, fig. 18, Lám VII y Lám. VIII, 1). Posteriormente, Argente la identificó como «tumba II» (Argente 1972) y Schüle como «tumba A» (1969: taf. 3), denominación con que la bibliografía posterior la presenta como paradigma de ajuar de gran riqueza (ej. Lorrio 1997: 158, fig. 63 o Cerdeño y García Huerta 2001: 171). El ajuar que lo acompañaba es, en efecto, uno de los más ricos de la necrópolis de Aguilar de Anguita por el número de objetos hallados y por las características de algunos de ellos. Lorrio lo incluye en la Subfase IIA1 del Alto Tajo-Alto Jalón, en siglo V a. C. y Quesada en la fase antigua de la panoplia ibérica.

- en cerámica: una urna de orejetas perforadas ${ }^{4}$, uno de los escasos ejemplares de este tipo dentro del mundo meseteño (Escudero 1990: 140, fig. 1, 4) y que tiene su origen en el Mediterráneo Oriental, a pesar de que el marqués decía era frecuente (Aguilera 1916: 18-19, fig. 5) ${ }^{5}$; y dos fusayolas.

- en hierro: una espada de antenas tipo Aguilar de Anguita (o tipo III de Quesada), con el armazón de cañas de la vaina que reforzaría una funda de materia orgánica, un soliferreum, dos puntas de lanza con sus regatones; un punzón que podría acompañar a los regatones; un pequeño escoplo; un cuchillo de hoja curva con mango damasquinado en cobre y con remate semicircular y otro sin mango; un radio de un escudo de radios;

4 Esta urna no figura en su conferencia ante la Asociación para el Progreso de las Artes Aguilera (1916, fig. 5), pero sí en la fotografía de la tumba en su obra inédita de 1911. Argente no la localizó cuando realizó su memoria de licenciatura (Argente 1971) y creemos que se encuentra inventariada, desde antiguo, como procedente de Luzaga, con el $\mathrm{n}^{\circ}$ 1940/27/Lz/770.

5 Hay que señalar que, según el propio marqués, la fotografía de la urna está manipulada, ya que la tapadera estaba muy rota y la sustituyó por una similar pero más pequeña, por lo que las asas de urna y tapadera no coinciden exactamente (Aguilera 1911: 22). 


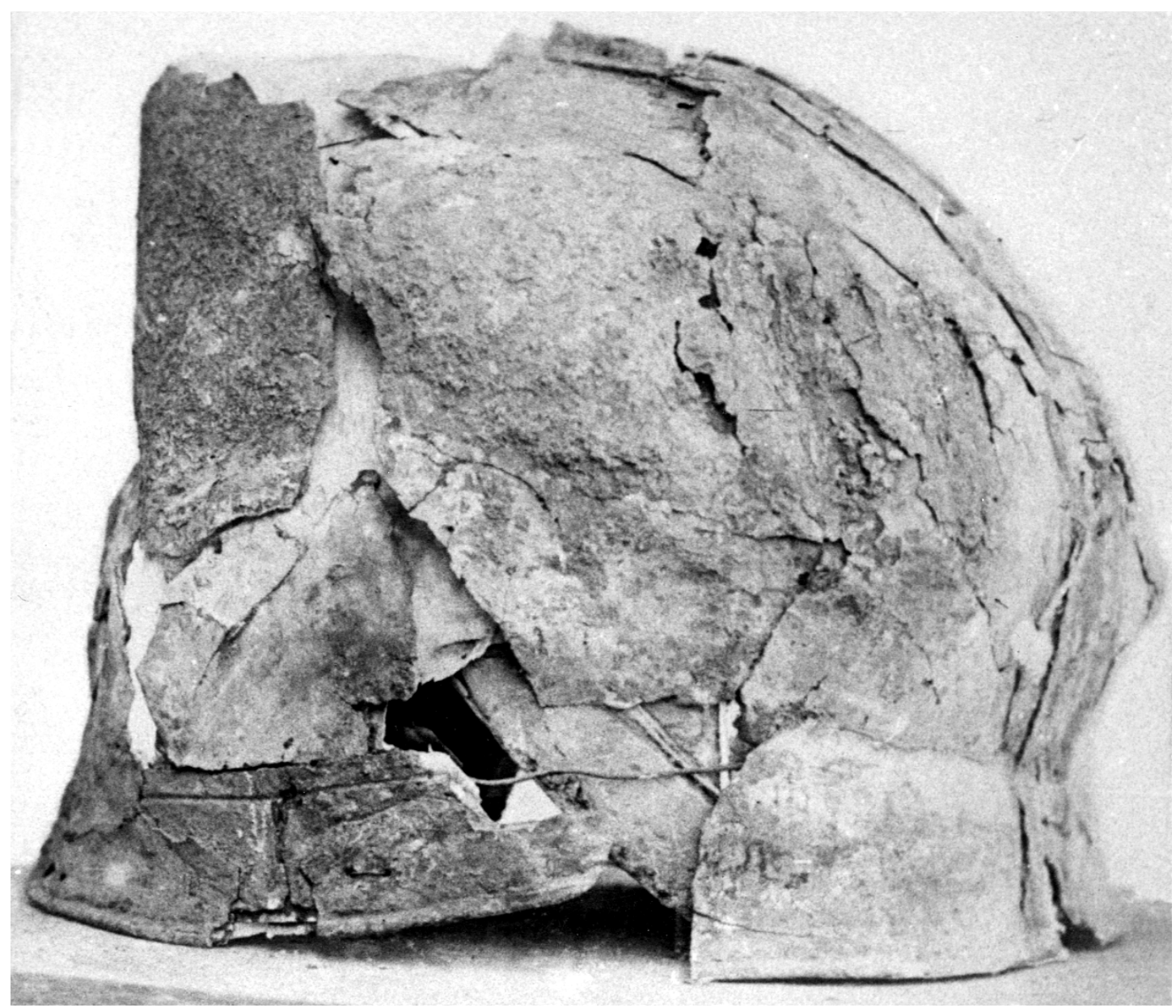

Fig. 2. Casco de Aguilar de Anguita tras la reconstrucción del Marqués de Cerralbo (Aguilera 1911: lám. CXLIII.2)

las dos manillas con anilla necesarias para llevar colgado un escudo circular (una de ellas rota); un bocado de caballo de doma o castigo con camas en artesa; un filete de bocado de caballo con agarrador ancoriforme; parte de dos camas, también en artesa, que formarían otro bocado de caballo; dos anillas con pasadores de botón para pasar las bridas del caballo y una anilla con agarrador; una pieza que no se conserva y que Aguilera describe como parte de los arreos del caballo; ocho láminas discoidales de $4,5 \mathrm{~cm}$. de diámetro con otro pequeño disco de bronce superpuesto y sujeto mediante remache central.

- en bronce: un pectoral compuesto por dos grandes discos y varias placas, todos ellos repujados y que constituye una de las piezas más conocidas de la tumba, también relacionada con el Mediterráneo central y oriental; una fíbula anular hispánica con puente de navecilla; dos pequeñas láminas recortadas con decoración repujada que podrían colgar del pectoral; tres discos pequeños de bronce; y el casco. Además, cuando el casco ha sido restaurado en el IPHE ${ }^{6}$ entre los restos del casco se han identificado res-

6 El casco comenzó a ser restaurado en el Museo Arqueológico Nacional por D. Antonio Sánchez Barriga, pero al trasladarse éste al IPHE, se solicitó una Orden Ministerial para que el casco fuese restaurado en centro, trabajo que finalmente realizó Dña. Soledad Díez. 
tos de una pequeña placa activa, rectangular, de cinturón, decorada con puntillado, y un fragmento de una pasiva, lisa, de mayor tamaño.

Si en su obra de 1916 fotografiaba las piezas de este ajuar expuestas sobre un cartón, en su obra «Páginas de la Historia Patria», con la que ganó el premio Martorell en 1911, había fotografiado la tumba in situ y descrito su estructura. Indica que esta tumba estaba rodeada de cinco adoquines colocados de canto y que la mayor parte del ajuar estaba fuera de la urna (Aguilera 1911: 20, lám. CXXIV). Sin embargo, ya se ha indicado en otro lugar (BarrilSalve 2000: 167-168, nota 19 y fig. 4, 5 y 6), que el propio marqués explicaba que preparaba la fotos y manipulaba algunos objetos antes de fotografiarlos y, por ello, disponemos de tres fotos de esta tumba con algunas discordancias entre ellas que nos impiden saber exactamente cómo apareció. En dos de ellas hay seis adoquines, aunque en distinta posición y en la tercera, precisamente en la que está fotografiado el casco, sobre la tierra, junto a la urna, el pectoral de discos y el soliferrum, sólo está uno de esos adoquines y lo denomina estela, lo que modifica el tipo de estructura funeraria (Aguilera 1911: lám. CXXIII, 1) (Fig. 1). Ese adoquín aparece en las otras dos fotografías, aunque sólo en una en la misma posición, lo que nos hace pensar que pudiera ser la original.

\section{Descripción (Fig. 5, 6 y 7)}

Antes de describirlo, es preciso recordar algunos aspectos de su historia tras el hallazgo y que pueden condicionar su presencia actual. El casco fue remontado por el propio marqués de Cerralbo según el mismo nos explica (Fig. 2), suponemos que años después, hacia 1972, fue parcialmente restaurado, pues en el archivo del M.A.N. existen fotografías de esa época, que muestran dos láminas, una al lado de la otra, no superpuestas, y cosidas con unos alambres (Fig. 3) que, en 1993, cuando, debido a su estado, se decidió acometer una nueva restauración, ya no existían (Fig. 4). Por ello, algunas pequeñas perforaciones que se observan en la zona de la cimera corresponderían a esos alambres contemporáneos y no al momento de su elaboración.

El casco (inv. MAN 1940/27/AA/287) es de bronce y con lámina decorativa de hierro, actualmente mide $21,5 \mathrm{~cm}$. de alto; $21,5 \mathrm{~cm}$. de profundidad, $15 \mathrm{~cm}$. de anchura máxima en el cráneo y 13,5 en el cuello. El grosor de la lámina es inferior a $1 \mathrm{~mm}$, aproximadamente 0,8 $\mathrm{mm}$, y tiene $4 \mathrm{~mm}$. de grosor en los rebordes. Se conserva además un gran fragmento correspondiente a la carrillera izquierda que mide $15,2 \mathrm{~cm}$. de alto y $16,7 \mathrm{~cm}$. de longitud, con el mismo grosor que el resto, y varios pequeños fragmentos que debido a su estado no es posible situar exactamente; unos, de bronce, completarían los huecos que se ven en la calota y otros, pequeños y de hierro, la banda decorativa. Su perímetro en la base, teniendo en cuenta las faltas, es de aproximadamente $53 \mathrm{~cm}$., de lo que se deduce que llegaría hasta cerca de las comisuras de la boca (fig. 5 a y b). La forma global del casco está actualmente deformada por aplastamiento lateral y apertura de las carrilleras, a lo que hay que añadir el estado de gran fragmentación en que fue descubierto.

Se trata de un casco realizado en dos láminas de bronce muy finas, moldeadas y batidas. Ambas mitades se superponen mediante sendas bandas verticales a modo de solapa que forman una franja vertical, de frente a nuca, enmarcada por dos nervios repujados (correspondientes uno a cada mitad), martilleada conjuntamente ${ }^{7}$ (Fig. 5 c). Los bordes vueltos hacia el interior, albergan en la parte interna e inferior del casco, en el guardanuca, una segunda lámina de bronce que serviría de refuerzo (Fig. 5 d).

7 Aunque hay alguna marca de pequeños agujeritos, los restauradores se inclinan a pensar que se trata de las huellas de los alambres con que se unieron tras su hallazgo y no de huellas de remaches del momento de fabricación (Díaz 1993). 


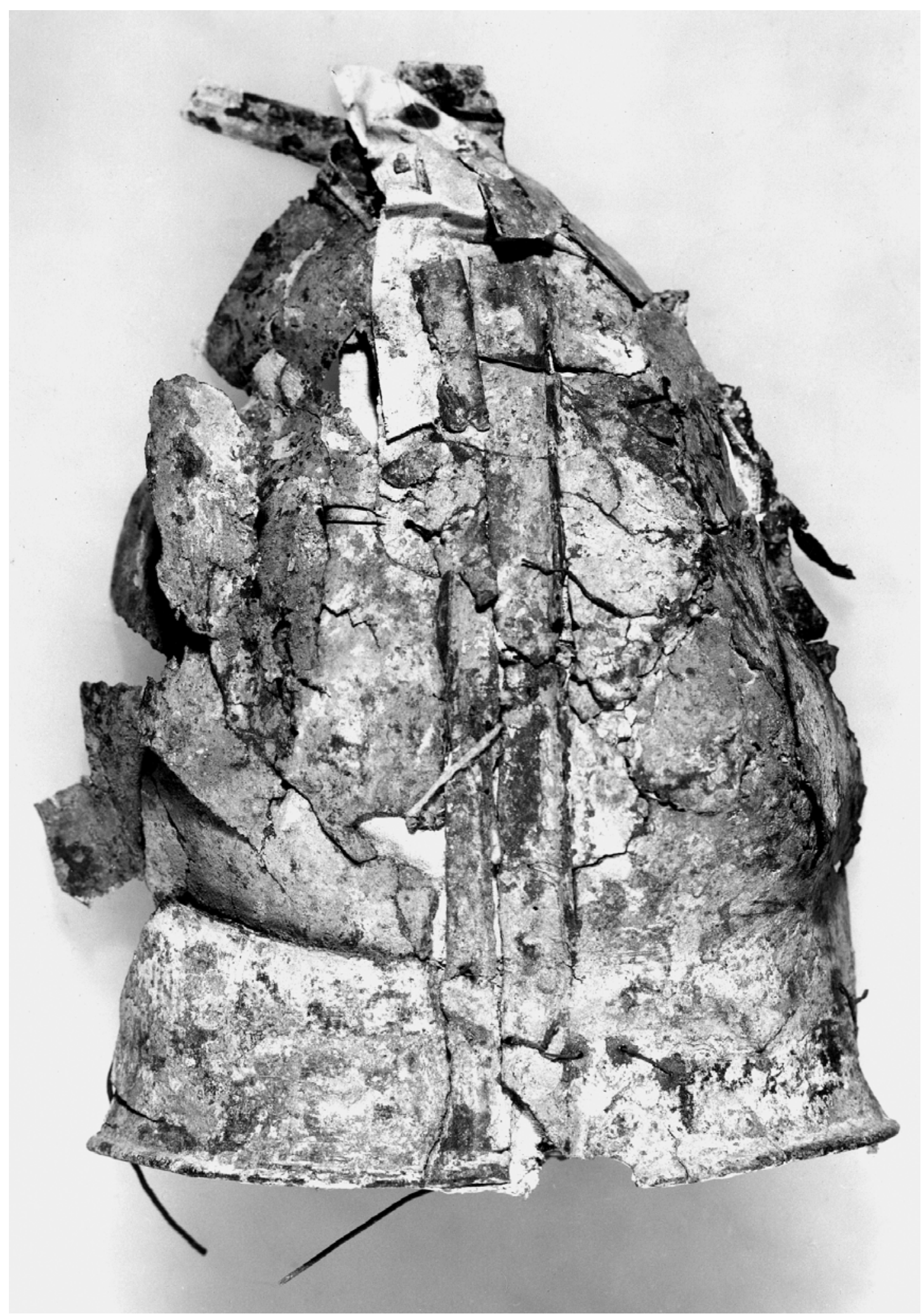

Fig. 3. Casco de Aguilar de Anguita, estado en 1972. Foto M.A.N. 


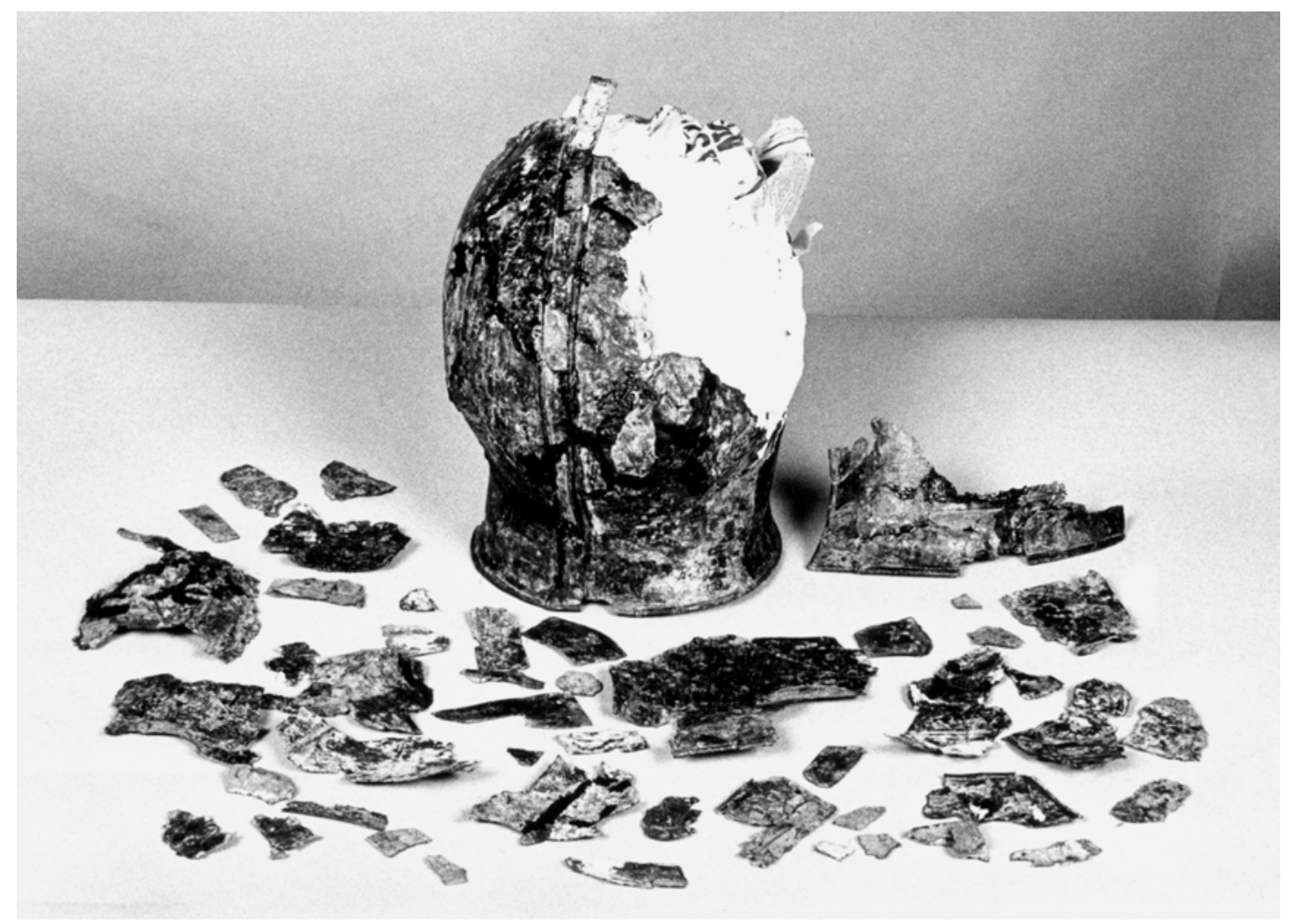

Fig. 4. Casco de Aguilar de Anguita, estado en 1993. Foto M.A.N.

El casco cubriría desde la frente a la nuca, protegiendo las orejas. La parte de la frente se encuentra muy incompleta, por lo que no es posible apreciar correctamente su forma y hay que señalar que de forma casi simétrica presenta a ambos lados un corte ligeramente diagonal, que sube desde el exterior hacia el centro de la cabeza; el del lado derecho parece recortado, mientras que el izquierdo se encuentra doblado hacia dentro. Estos cortes se situarían bajo el ojo y en relación con la forma que adopta la citada carrillera que se conserva en un fragmento aparte.

A unos cinco $\mathrm{cm}$. del borde inferior la calota se curva hacia fuera para formar el guardanuca, es un borde ancho cuya línea de cambio de inflexión no es recta, sino que está más baja justo en el centro posterior, y se eleva ligeramente hacia los lados.

El borde de casco se decoraba exteriormente con una cinta de hierro de $2,5 \mathrm{~cm}$. de alto, que falta en muchos puntos pero cuya huella permanece, muy degradada; se conserva parcialmente en la carrillera izquierda donde hay dos láminas de hierro superpuestas. La decoración, se aprecia mejor en el lado derecho, donde dentro de la misma cinta se observa una franja paralela al borde inferior, de la que queda una línea de ondas contrapuestas sobre líneas incisas horizontales y falta el resto y, otra franja paralela al lateral, aparentemente simétrica, con una serie de finas líneas verticales junto a los bordes (que podrían tener en su interior aspas o zig-zags, muy perdidos), una línea de ondas contrapuestas incisas enmarcados por dos finas líneas, y entre ambos grupos una banda vertical en la que se aprecian marcas diagonales paralelas y desiguales, que podrían ser de fabricación o de limpieza (fig. 6).

En el lado derecho, en la carrillera, a la altura de la nariz aproximadamente hay huellas de un disco de 4,5 cm. de diámetro. Hay otro fragmento de 7,1 x $6 \mathrm{~cm}$. que presenta dos lados 
a
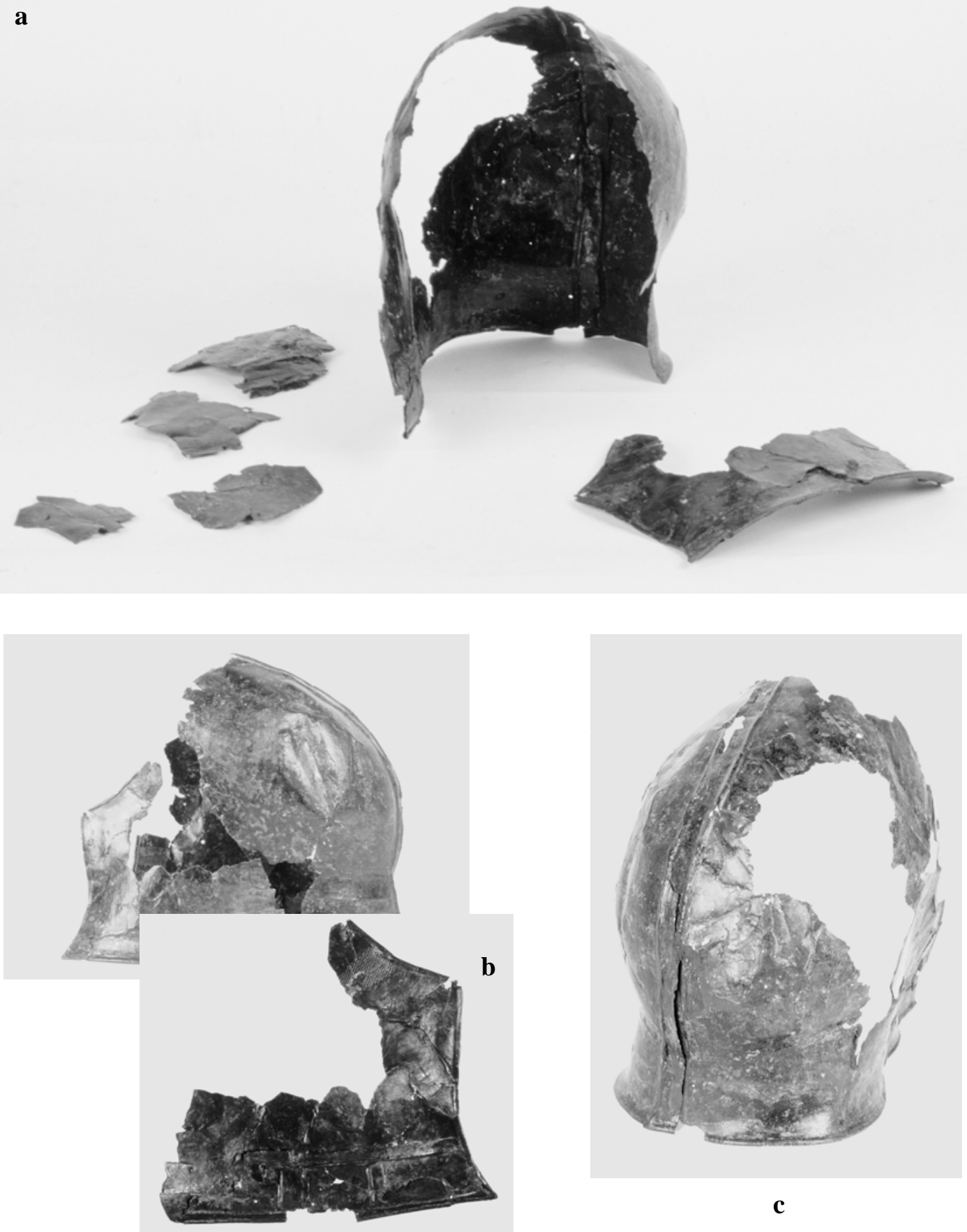

d

Fig. 5. Casco de Aguilar de Anguita, estado actual. Foto M.A.N. Angel Rodríguez. Figs. 5 a. Vista de frente y fragmentos; $5 \mathrm{~b}$. Vista lateral izquierdo; $5 \mathrm{c}$. Vista posterior; $5 \mathrm{~d}$. Reverso de la carrillera izquierda. 


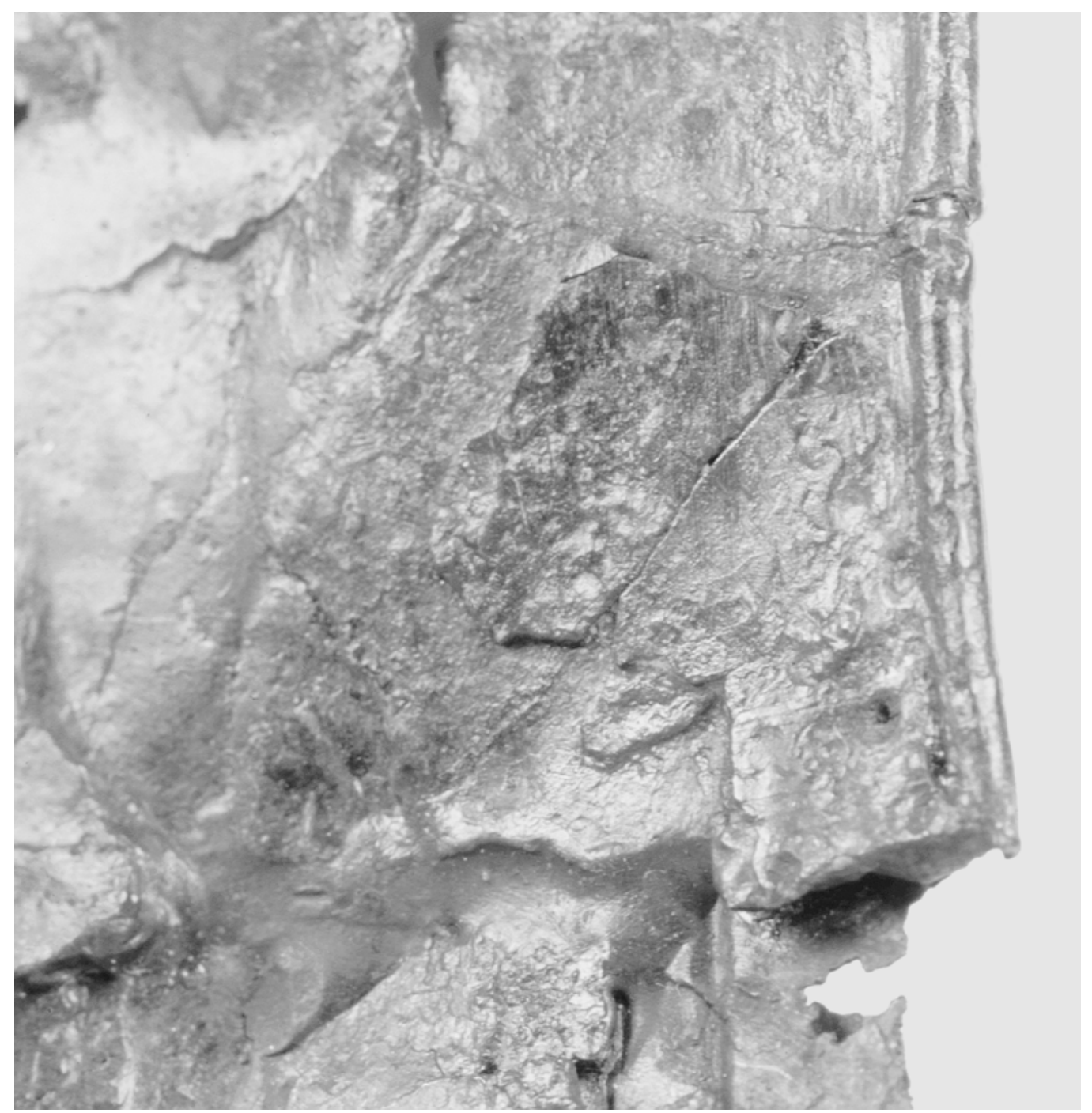

Fig. 6. Casco de Aguilar de Anguita, detalle de la cinta de carrillera derecha. Foto M.A.N. Ángel Rodríguez.

cortados con inclinación similar a la carrillera y la línea que bordearía los ojos y que tiene también marcas de un arco de círculo manchado de hierro, de $5 \mathrm{~cm}$. diámetro. No descartamos que alguno de los discos de hierro con otro de bronce superpuesto, antes mencionados, pudieran haber sido la causa de estas huellas.

El borde interior del casco, en la zona del guardanuca, se encuentra reforzado por otra lámina de bronce, de $4,3 \mathrm{~cm}$. de altura, que está compartimentada por nervios, uno largo, superior, horizontal y otros cortos, transversales.

Entre los fragmentos del casco no hemos localizado ninguno que pueda considerarse un nasal ${ }^{8}$, por ello pensamos que la línea de la frente sería horizontal y bajaría lateralmente jun-

8 Entre los fragmentos hay uno de $2 \mathrm{~mm}$. de grosor, alargado, pero de bordes recortados y algo informe que se ha considerado pertenece a la placa pasiva de cinturón. 
to a los ojos, pasaría bajo ellos en diagonal hacia las aletas de la nariz y allí cambiaría de inflexión para bajar hacia la barbilla cerca de las comisuras de la boca.
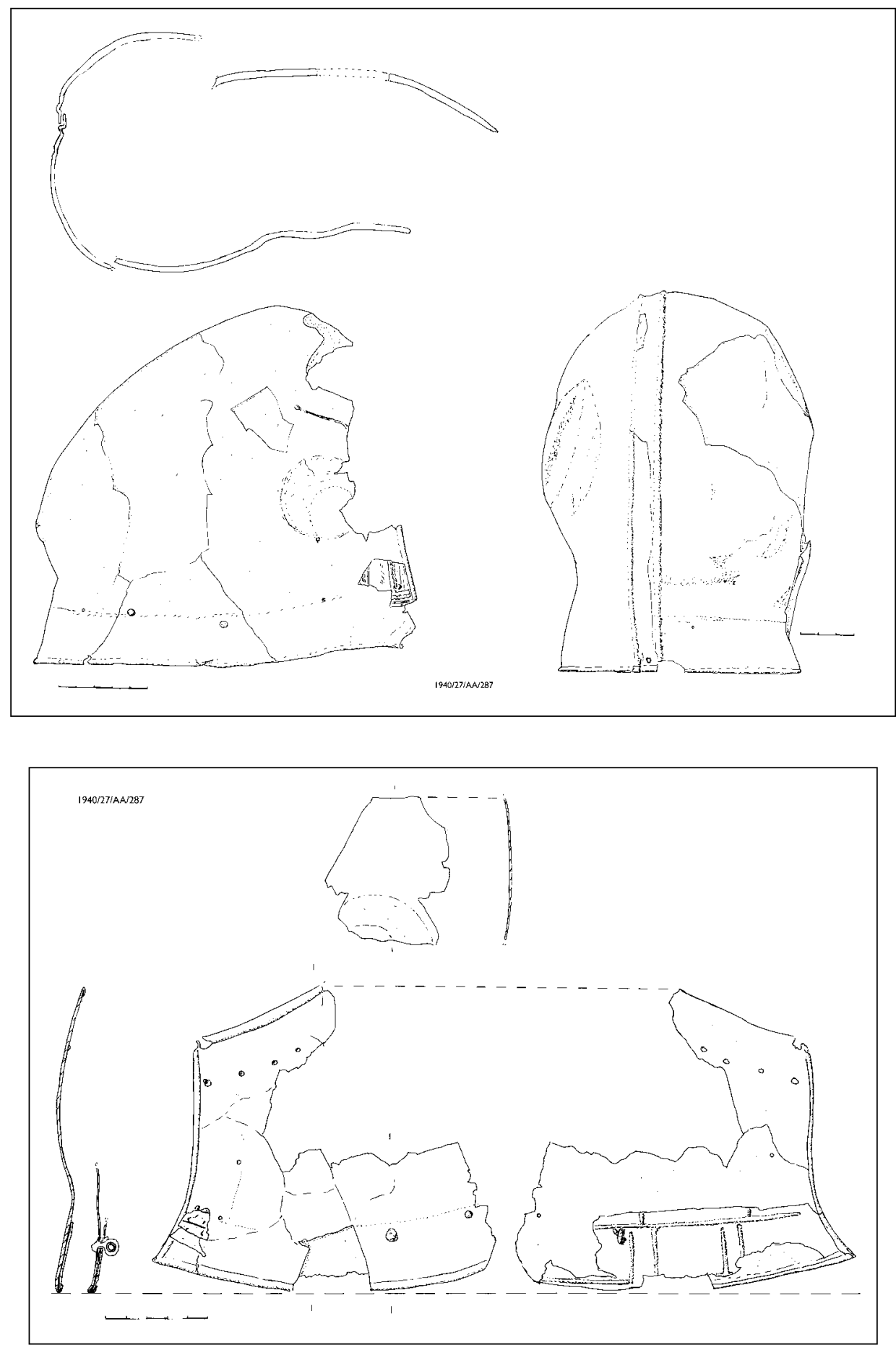

Fig. 7. Casco de Aguilar de Anguita, estado actual. Dibujo M. Barril. 7 a. General; 7 b. Carrillera izquierda. 
En la carrillera izquierda hay un gran remache a $10 \mathrm{~cm}$. del borde, junto a la barbilla. Este remache se corresponde en el interior con una anilla de hierro que tiene un pequeño vástago, también de hierro, en su interior, y restos de otro remache similar a $4 \mathrm{~cm}$. en dirección al centro del casco (fig. 7 b). En la otra carrillera hay otros dos remaches o su huella, en la misma situación que estos dos. Los remaches, que es posible que sean el indicio de otras anillas, quedarían situados delante y detrás de la oreja, por lo que proponemos que sujetasen un barboquejo de doble unión al casco, que de esta forma se nivelaría.

La calota de láminas de bronce se ajustaría a la cabeza, pero su endeblez hace suponer que iría colocado sobre un capacete de cuero, u otra materia orgánica, sujeto entre las dos láminas de bronce del borde inferior (fig. $7 \mathrm{~b}$ ).

El casco presenta en su costado izquierdo dos golpes alargados, hendidos en ' $\mathrm{V}$ ' de 7 $\mathrm{mm}$. profundidad y realizados lateralmente por una hoja perpendicular al mismo, que suponemos podría ser de una espada. Golpes de ese tipo son frecuentes en cascos griegos e itálicos, hallados amortizados en tumbas o depósitos, y se ha propuesto que se realizarían para evitar su reutilización, lo mismo que la apertura y deformación de la carrilleras, independientemente de que pudieran haberse producido los golpes en uso (Olmos 1988: 56).

\section{Analítica y técnica de fabricación}

Este casco ha sido analizado en varias ocasiones a petición de los distintos restauradores que se sucedieron en la labor de consolidarlo. Algunos de los resultados difieren ligeramente entre si, por lo que D. Salvador Rovira explica esas aparentes divergencias y la técnica de fabricación de éste y de los demás cascos en un apéndice que acompaña este trabajo.

Adelantamos que se trata de una pieza realizado en un bronce binario, apto para ser trabajado mediante martilleado en frio y laminarlo para darle forma.

En este caso se trataría de una pieza realizada en dos láminas unidas solapando una sobre otra en lo que constituiría el centro de la cabeza y otra lámina que recorrería toda la parte inferior interna, quedaría embutida en un reborde de las láminas externas y fija por los pequeños remaches que desde el exterior mantendrían en su lugar la cinta decorativa de hierro y los remaches de hierro con anilla al interior permitirían sujetar el casco al cuello. Está lamina interna, debido a la disposición de las pérdidas, ignoramos si sería una sola, continua, o estaría también dividida en dos.

\section{Adscripción tipológica}

La costumbre tradicional de buscar paralelos a determinadas piezas e incluirlas dentro de tipos para delimitar su área de procedencia ha sido a veces denostada por rígida y artificial; pero cuando se trata de objetos tan elitistas y escasos en el registro arqueológico, como los que aquí presentamos, si parece necesario establecer posibles relaciones comerciales o personales entre distintas áreas geográficas, como lo demuestra el trabajo de Cerdeño, Sanmartí y García Huerta (1999).

Aguilera, en su obra mecanografiada (1911: 57, lám. CXLVII.2 y 3), describió el casco como «...es un verdadero casco con cubre-nuca y carrilleras, es decir prolongaciones para defender el cuello y los costados de la cara...... tiene de alto $0 \mathrm{~m} 21$ por $0 \mathrm{~m} 25$ de ancho desde el borde medio de su cubre faz hasta el surco central, que le divide en dos mitades iguales. De esa forma en su época, no creo que se haya encontrado hasta el día ninguno», explica a continuación que estaba fragmentadísimo y que intentó pegar las piezas pero sin reformarlas. 
Algo más tarde (Aguilera 1916: 34, fig. 18) lo describía como casco que «mide $0.21 \mathrm{~cm}$. de alto por $0.23 \mathrm{~cm}$. de ancho, desde el borde de la carrillera hasta el empalme central que le divide en dos mitades; es completamente diferente de los figurados en las monedas ibéricas, aunque ya dije que éstas son mucho más modernas que mis necrópolis. Sospecho que este casco se asemejará a los corintios, que otros llaman beocios». Quesada piensa que esa descripción no se corresponde con uno corintio y pudiera ser un casco griego de tipo arcaico (Quesada 1997: 553).

También Schüle lo define como casco de tipo corintio del VI a.C. (Schüle 1969: 116; taf. 3.27) debido a que las fotos antiguas presentaban una vista de tres cuartos lateral posterior en la que se apreciaba el guardanucas en forma curvada y la calota redondeada. Otros autores como García Mauriño (1993: 93) o Lorrio (1997: 167, fig. 63) no se atreven a adscribirlo a ninguna tipología concreta; este último lo encuadra en la Subfase IIA1 de las necrópolis celtibéricas del Alto Tajo-Alto Jalón debido al resto del ajuar que lo acompaña.

Más recientemente, se ha mencionado que la restauración de este casco ha revelado que se trata «de un casco de tipo corintio con guardanuca y carrilleras, único hallado en tierras interiores» (Cerdeño, Sanmartí y García-Huerta 1999: 272), pero, como veremos, no consideramos exacta esta aseveración.

Otra interpretación histórica sobre la adscripción tipológica del casco la proporciona una fotografía del casco, la n ${ }^{\circ}$ D. 2948 del Archivo Fotográfico de Cabré, custodiado en el IPHE que muestra el casco original, reconstruido por el marqués ${ }^{9}, \mathrm{y}$, otra fotografía, la $\mathrm{n}^{\mathrm{o}} 1359^{10}$, que muestra un dibujo del propio Cabré, que lo reconstruye idealmente como un casco de cara despejada, frente cubierta, guardanuca curvado y paragnátides independientes, similares a las que llevan los cascos de tipo Montefortino (Fig. 8). Cabré pensaba que se trataba de un casco de tipo itálico debido a la endeblez de la lámina y coloca, de forma hipotética, como yugular el fragmento que una vez restaurado se ha comprobado que es la carrillera izquierda. Según esta reconstrucción el casco llevaría una ancha cenefa decorativa rodeando el rostro y una estrecha en la zona de la curva del guardanuca.

En esta misma línea iba la propuesta de Blázquez (1960: 383, nota 4), quien lo relacionaba con el $\mathrm{n}^{\circ} 149$ del grupo B del catálogo de Jacobsthal (1944: 118, 189, lám. 88, ${ }^{\circ}$ $149)^{11}$, un casco con pequeño guardanucas, remate cónico añadido y dos yugulares que se sujetarían con remaches ${ }^{12}$; un tipo de casco que Jacobsthal considera realizado en Italia y fruto de la colaboración de artesanos etruscos y celtas.

El casco de Aguilar de Anguita debido a que está incompleto, no podemos adscribirlo de forma definitiva a ningún tipo de casco antiguo conocido, pero si contiene elementos de varios modelos procedentes de las áreas oriental y central del Mediterráneo y, similitudes y diferencias con los que conocemos en la iconografía de la estatuaria peninsular que vamos a señalar.

1. Tiene algunos paralelos con los cascos corintios típicos con los que se le asoció en el momento de su descubrimiento, como son el casquete redondeado y ensanchado y la decoración en el borde; pero tiene también diferencias como la mayor curvatura del guardanucas, la probable ausencia de nasal, la extrema delgadez de la lámina de bronce y el hecho de estar realizado en dos mitades.

\footnotetext{
9 La que Enrique de Aguilera y Gamboa incluye en sus obras de 1911 y 1916 ya citadas.

10 Agradecemos a Dña. Belén Rodríguez Nuere, conservadora de las colecciones de fotografía del Instituto de Patrimonio Histórico Español la posibilidad de haber consultado esta documentación inédita.

11 Hay muchos más autores que han mencionado en sus trabajos el casco de Aguilar de Anguita pero sin precisar y, relacionándolo con cascos de tipo céltico- itálico o Montefortino. Sin ánimo de ser exhaustiva señalaré los de Wattenberg (1959: tabla XVIII, cascos 3), Abásolo y Pérez (1980: 13) o Stary (1982: 134)

12 Jacobsthal pensaba que las yugulares pertenecieron inicialmente a otro casco por la diferencia de pátina y estar sujetas con un hilo cuando él lo estudió
} 


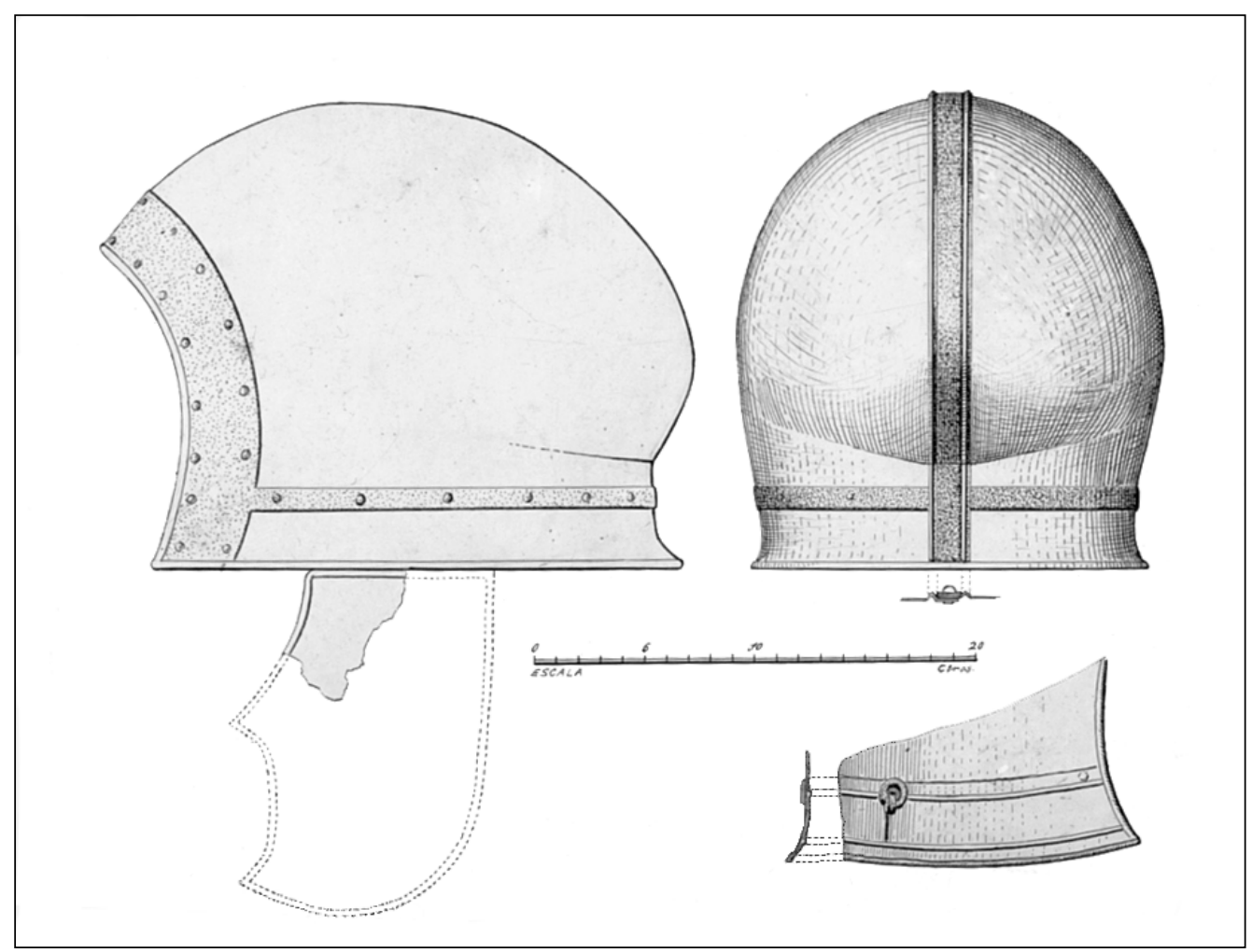

Fig. 8. Casco de Aguilar de Anguita, reconstrucción según Juan Cabré Aguiló. Archivo Fotográfico Cabré. I.P.H.E. Ministerio de Educación Cultura y Deporte, nº 1359.

En efecto, los cascos corintios se caracterizan por ser muy cerrados, de una sola pieza, con los ojos enmarcados, con nasal, reforzada o no, y las carrilleras muy adelantadas dejando una pequeña apertura en la boca. Muchos de ellos llevan en el borde decoraciones incisas en el mismo casco y algunos en una lámina superpuesta. Uno de los parámetros para establecer la evolución de los cascos corintios es la curva del guardanucas que se va acentuando con el transcurrir del tiempo, mientras que al comienzo era prácticamente inexistente.

Lo usual es que sean de una pieza, considerándose la realización en dos mitades verticales como característica de los cascos cretenses antecedentes de los corintios. Se conoce, no obstante, alguno corintio realizado en dos mitades, así uno de Olympia, datado en la primera mitad del siglo VII a.C, (Kunze 1961:130, fig. 100-101) del tipo C5 de Snodgrass y grupo 2 de Kukahn y que este investigador relacionó con los itálicos, aseveración con la que no está de acuerdo Snodgrass, quien considera que los itálicos tienen las dos mitades horizontales y son cronológicamente posteriores (Snodgrass 1964: 24, fig. 11 y 13).

Sin embargo, de Lombardia, Italia, si conocemos al menos uno en dos mitades verticales que se unen solapándose y con remaches, conformando una franja vertical de líneas paralelas decorativa; el borde de la cara tiene los bordes perforados, posiblemente para remachar una cenefa. Es un casco todavía muy vertical, cuyo guardanuca forma un ángulo brusco cerca del borde (Antike Helme 1988, 393, nº 15, Inv. Berlin L 2) y que se asemeja bastante al de Aguilar, pese a la ausencia de nasal en éste. Nos interesa también otro casco de tipo corintio, con el nasal incompleto, lamentablemente de procedencia desconocida, y que tiene la calota más ancha que el anterior, una banda vertical decorativa que lo divide en dos mitades y bordes vueltos hacia el interior formando un engrosamiento que constituye el límite inferior de la 
cenefa que lo rodea, y en la que quedan remaches de sujeción (Antike Helme 1988, 390, n $^{\circ}$ 13, inv. Berlin L 92).

En la Península Ibérica se han hallados muy pocos cascos corintios, los dos conocidos desde antiguo, los hallados en el río Guadalete, en Jerez y en la Ría de Huelva y otro más reciente, en la desembocadura del río Guadalquivir. Olmos al reestudiar el de la Ría de Huelva destaca su perfil, más curvo y horizontal que el de Jerez, como indicativo de mayor modernidad, lo que corrobora su mayor ligereza, con 13 micras de grosor, y el presentar el borde con una franja decorativa, que sustituye a las perforaciones que bordean el de Jerez y que piensa permitiría sujetar con remaches una funda de cuero bajo el bronce para amortiguar su peso (Olmos 1988: 55). De cualquier manera, ambos, son cascos con una lámina de bronce más gruesa que la del de Aguilar de Anguita, en concreto el de Jerez mide $2 \mathrm{~mm}$ de grosor medio y algo menos en el borde inferior posterior ${ }^{13}$ y cuando, el de la Ría de Huelva, coincidió en el tiempo en el Servicio de restauración del IPHE, con el de Aguilar de Anguita, se pudo comprobar que los posibles paralelos entre ambos estaban muy matizados y lejanos. Por otro lado hay que señalar que, la técnica de fabricación por batido de estos cascos, implica que el grosor de la lámina es muy difícil que fuese absolutamente homogéneo.

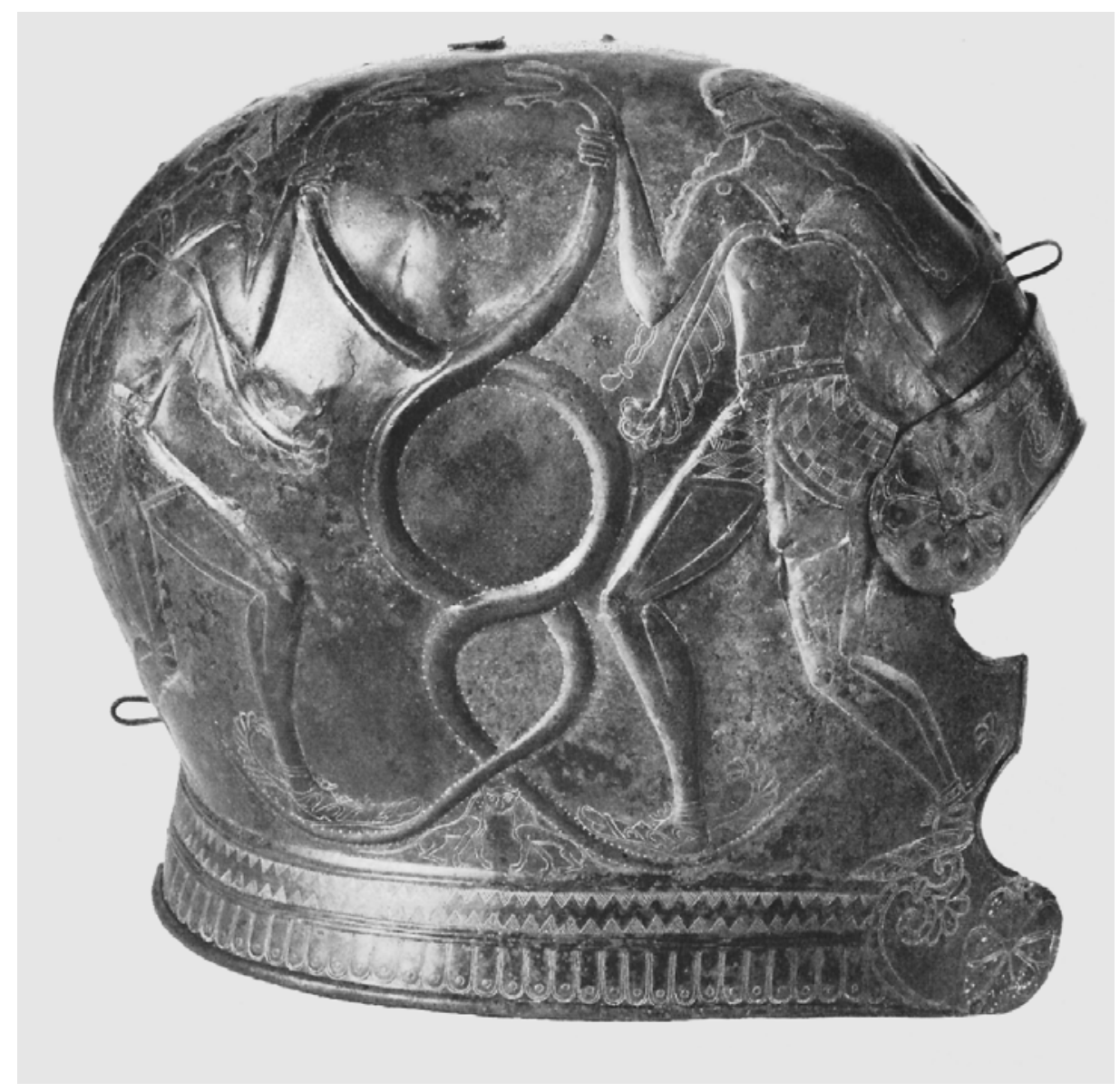

Fig. 9. Casco cretense (Bothmer 1979, $\mathrm{n}^{\mathrm{o}} 89$ ).

13 Agradezco a Dña. Rosalía González y a Dña. Carmen Martín Mochales, directora y restauradora respectivamente, del Museo de Jerez, las facilidades prestadas para su consulta. 
2. Más interesantes para nuestro estudio nos parecen varios cascos del ámbito egeo, de los siglos VIII a VI a.C. que llevan carrilleras adelantadas, sin nasal y con cimera y que están realizados en dos mitades verticales (Schauer 1988: 192, Abb. 9); así, los cascos procedentes de Afrati, Creta, se componen de dos mitades con decoración repujada figurada en la calota y llevan guardanucas continuo con decoración de zig-zags, triángulos y ovas incisos y nervios divisorios; las carrilleras avanzadas, pero no cerradas, decoradas y, un estrecho frontal abatible (visera móvil), unido a la calota en los extremos por remaches, aunque sólo uno de los dos cascos lo conserva (Bothmer 1979: 140, fig. 89 y 90) (Fig. 9) ${ }^{14}$. Otro modelo de casco cerrado y cara despejada, aunque con prolongaciones laterales y un apéndice sobre la calota, se representa en los aribalos rodios de terracota del siglo VI en forma de busto de guerrero (Bothmer 1979: 160, n 115) (Fig. 10). Relacionado con estos modelos, es el casco que luce una cabeza en piedra, etrusca, de Orvieto, de carrilleras adelantadas, sin nasal, con guardanucas curvado y restos de una cimera en la parte superior de la cabeza, en el centro (Stary 1981: taf. 30.1) (Fig. 11) o el que lleva la estatuilla de bronce, procedente de Ravena que se dice representa a Laran, el dios etrusco de la guerra, y se data entre 540 y 520 a.C. (Pallotti-

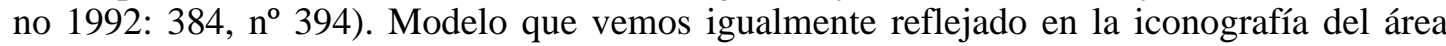
etrusca y picena, también en la Península italiana, unas veces con penacho sobre soporte, como en un cipo etrusco de Chiusi (Stary 1981: taf. 32.1) o con cimera transversal, de oreja a oreja, o longitudinal, de frente a nuca, y otras sin; en particular indicamos los representados en corazas picenas de Rapagnano (Stary 1981: taf. 59. 1 y 2) (Fig. 12), aunque Stary no propone ningún mapa de distribución de elementos reales de este tipo. Creemos que es a este modelo al que se asimilaría el casco de Aguilar de Anguita, que pudo llevar una cimera longitudinal y adornos.

3 a. Con estos cascos que acabamos de citar se han relacionado las calotas de los representados en la iconografía de la Península Ibérica, en esculturas y exvotos, pero carentes de las carrilleras. Precisamente, Negueruela llegó a similar conclusión en su estudio sobre las esculturas de Porcuna. El casco del denomina «guerrero ibérico $n^{\circ} 1$ » llevaría cimera, algún elemento, desconocido, adosado sobre la frente y a ambos lados de la cabeza unas patas de felino que soportarían la cimera. Los demás cascos portarían también cimeras elevadas y, variando este elemento, Negueruela propone tres reconstrucciones de los cascos (1990: fig. 18 y 19). Son cascos que protegen la parte posterior de la cabeza hasta el inicio del cuello; cubren escasamente la frente y bajan verticalmente a ambos lados de la cara, bordeando el casco una moldura que Negueruela duda, entre que represente un reborde blando, de cuero, para amortiguar el movimiento, o bien una franja decorativa del casco. Los laterales están decorados por grandes espirales de las que quedan restos en las esculturas. Para reconstruir este modelo que propone, y supone — sin afirmarlo- que puede ser de metal, parte de los restos escultóricos de Porcuna y se fija en modelos de cascos conocidos por la iconografía monetal, pictórica o plástica. Y es precisamente en los cascos jonios, similares a los representados en los aribalos rodios en los que mayores paralelismos encuentra; pero, destacando que en Porcuna, faltan las carrilleras móviles que caracterizan a este tipo de cascos (Negueruela 1990: 136) y que si tiene, aunque fijas, este de Aguilar de Anguita. Negueruela cree que los cascos de los guerreros de Porcuna derivan de los cascos jonios, pero no directamente, sino a través de intermediarios, tal vez centro-itálicos o etruscos, que reelaboraron el modelo, que a su vez pudo ser «reinventado» por la creatividad ibérica. También se plantea por qué motivo no se conocen originales hallados en excavaciones, y supone aparecerán en algún momento, ya que el resto de las armas que llevan las esculturas si existen (1990: 138). Tal

14 Agradezco a D. Raúl Areces Gutiérrez, Técnico del Gabinete de Prensa del M.A.N. y a Dña. Mar Alfaro Arregui, Licenciada contratada del Departamento del Protohistoria y Colonizaciones del mismo museo, su ayuda en el tratamiento informático de las imágenes de este trabajo. 


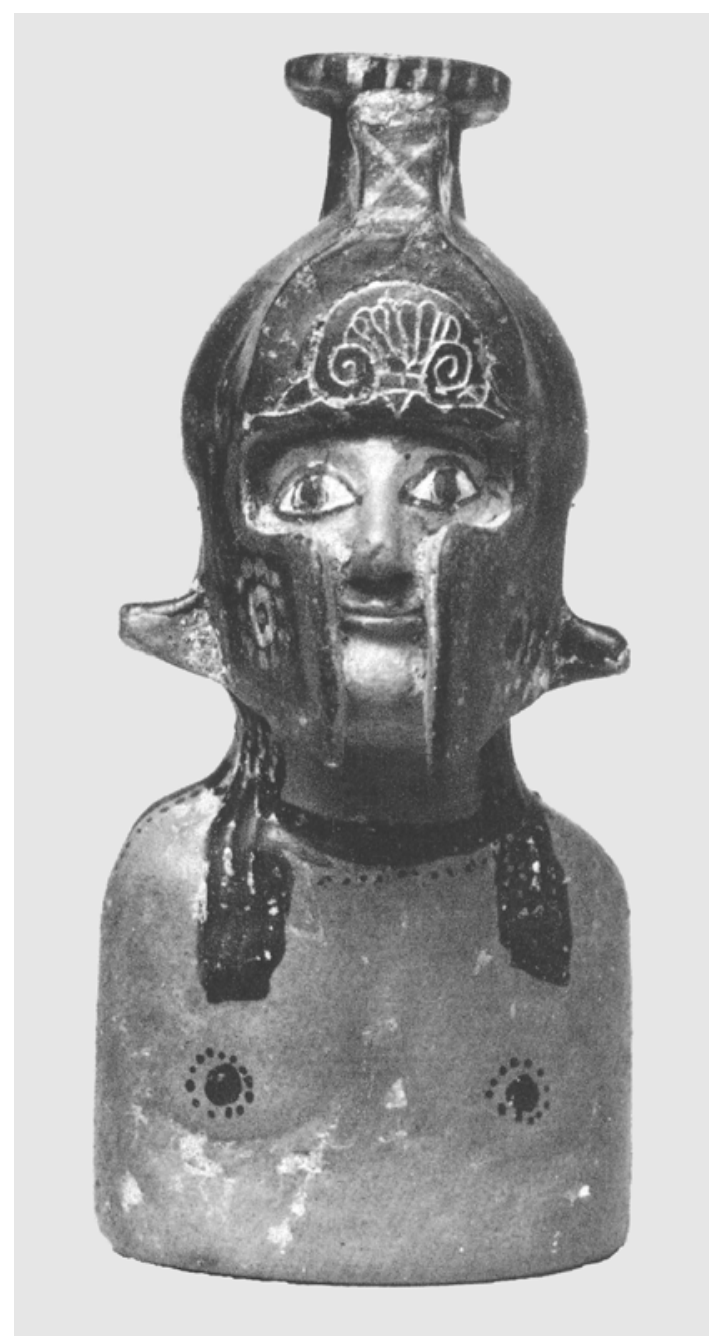

Fig. 10. Aribalos rodio (Bothmer 1979, $\mathrm{n}^{\circ}$ 115).

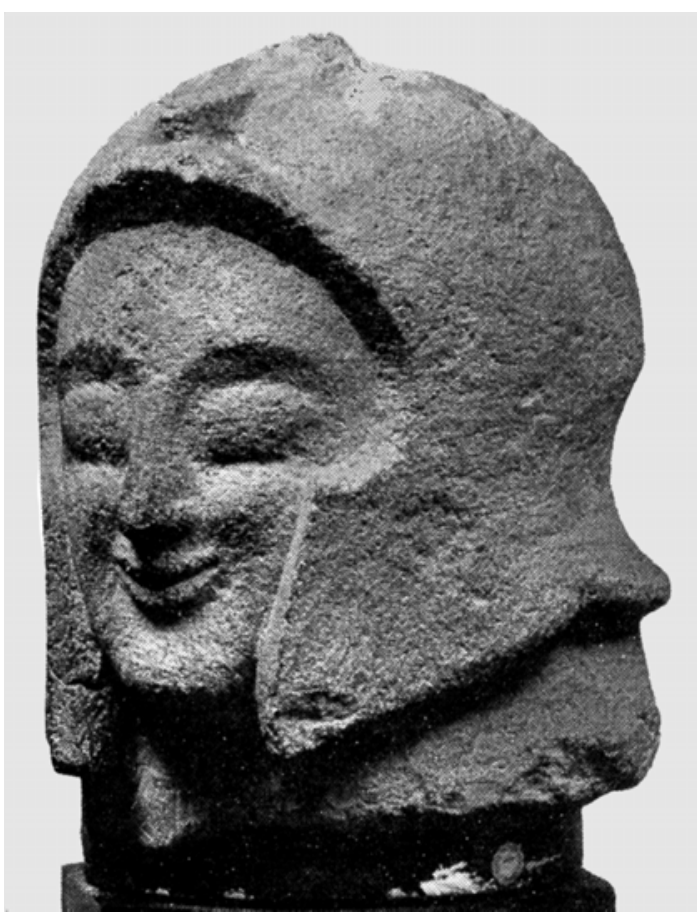

Fig. 11. Cabeza etrusca en piedra de Orvieto (Stary 1981: taf. 30.1). 
vez este casco de Aguilar de Anguita sea uno de esos intermedios que él buscaba, no en vano también halló en el pectoral de la misma tumba a la que pertenece el casco, y en otras de la misma necrópolis, paralelos para los disco-coraza que llevan algunos de los guerreros ibéricos de Porcuna.

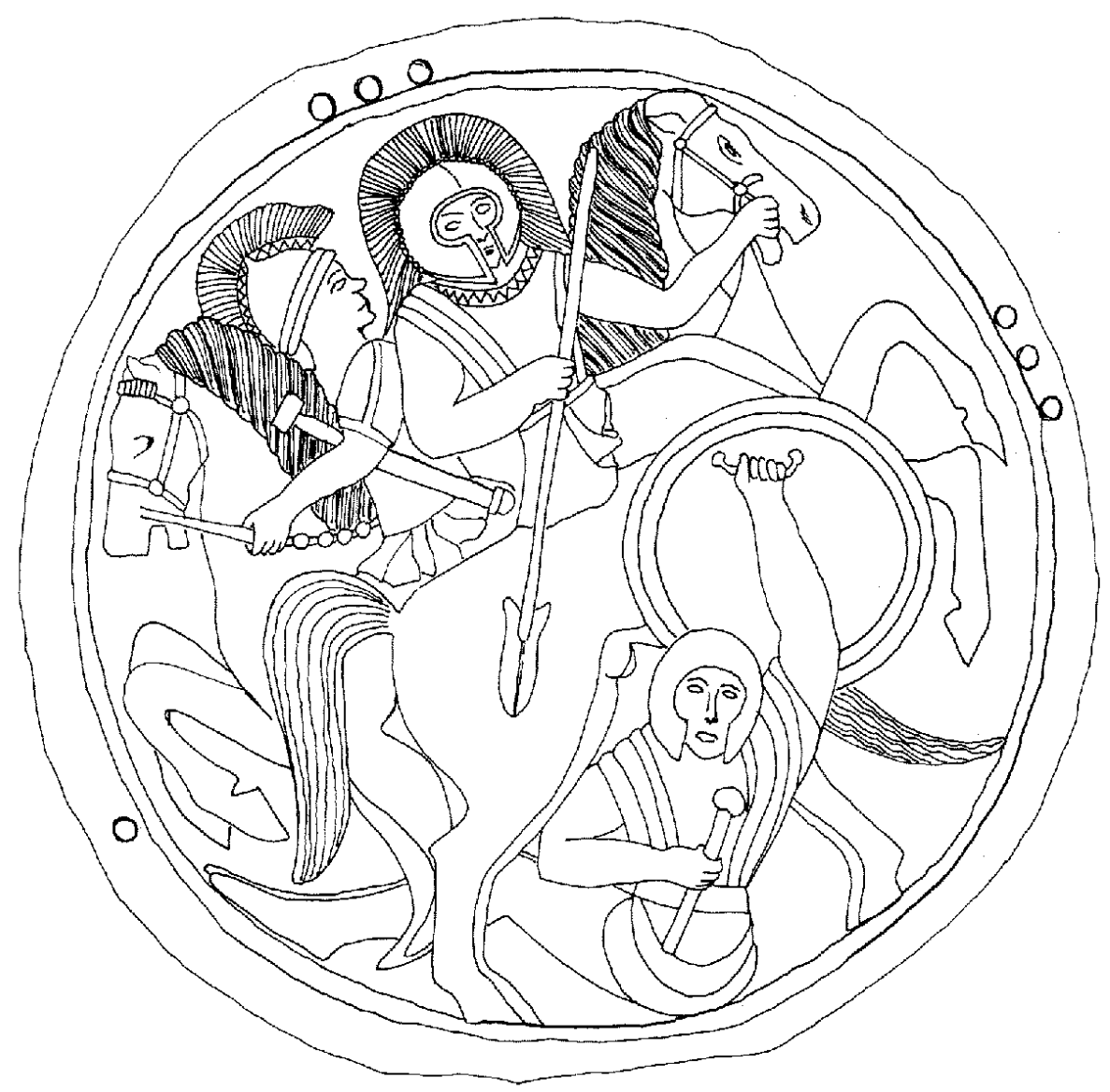

Fig. 12. Coraza picena de Raspagnano (Stary 1981: taf. 59.1).

3 b. Negueruela alude también a los pequeños exvotos ibéricos en bronce, algunos de los cuales - muy pocos en proporción a su número- se cubren la cabeza con cascos que podrían ser de cuero o metal. De entre ellos, poquísimos, tienen cimera elevada, y de éstos el más conocido es el de la Bastida de les Alcuses, Valencia, con un gran penacho que cae hacia la espalda y parte de un soporte sobre la parte anterior de la calota (Kukhan 1960). Los pocos cascos sin cimera tienen el casquete similar, y otros exvotos llevan un tocado que, para un grupo de autores como Nicolini, es un peinado y, para otros como Cabré, un casco que cree de materia orgánica. En efecto, los cascos que llevan algunos de los exvotos en bronce de los santuarios ibéricos de La Luz o Collado de los Jardines son de cimera baja, o bien de calota lisa con orejeras y una línea horizontal a la altura de la nuca, que a veces hace dudar si se trata de un casco o de un peinado de media melena ${ }^{15}$. Destacamos los cascos, indiscutibles,

15 ej. Prados 1992: 75, uno del grupo III B 1, el n. 1014, de La Luz; u otro de Collado del grupo CIIc, n. 149. 
que llevan dos exvotos masculinos oferentes de Collado de los Jardines, $\mathrm{n}^{\mathrm{o}}$ Inv. 28614 y 28615 del MAN, que cubren toda la cabeza con un casco de grueso reborde en la parte inferior y una alta cimera que recorre el centro del casco verticalmente; en ambos casos la cara queda despejada, pero en el primero (Fig. 13) las carrilleras están algo mas avanzadas hacia la boca (Álvarez Ossorio: 61, lám. XXXVII, no 230 y 232). Estos cascos tienen la misma calota que el de la Bastida de les Alcuses, pero se diferencian en que la cimera está repartida en una línea vertical a lo largo de la cabeza. Cascos similares, algunos con llamativas crestas se representan en las cerámicas ibérica de San Miguel de Liria, pero no entraremos en detalles ya expuestos en otros lugares (Quesada 1997: 568). Kukhan en 1960 había señalado una posible, pero muy remota, influencia italo-griega en el casco de esta figura de La Bastida y el resto de las figuras ibéricas (Kukhan 1960: 156) y creemos que así puede ser ya que las variedades de cascos de los exvotos están presentes en un friso del Templo etrusco de Veii (Stary 1981: taf. 38.3), en el que también se representa alguno corintio, con penacho igual (Stary 1981: taf. 38.2); es decir que los modelos coexistirían y posiblemente se individualizarían según sus portador.

4. Dentro del territorio celtibérico, también se representan cascos similares en la iconografía vascular, como el de Ocenilla, Soria (Taracena 1932: 49, fig.9), figura que a pesar de estar simplemente silueteada y rellena en una sola tinta se aprecia un casco cerrado que baja hasta la nuca y lleva un largo penacho que cae hacia la espalda y parte de un soporte en la parte anterior del mismo (Fig. 14), como en el caso del exvoto de La Bastida. También los combatientes del conocido «Vaso de los Guerreros» de Numancia (Romero 1976: 21, $\mathrm{n}^{\circ}$ 20,fig. 4, lám. II), llevan cascos con la cara despejada, cerrados bajo la barbilla, muy pegados a la cabeza por lo que parecen de materia orgánica y con cimeras variadas. Pero si nos fijamos en la iconografía monetal encontramos una gran variedad de cascos (Lorrio 1995: 78), la mayoría son cascos con botón terminal, pero hay algún caso en el casco parece de tipo corintio cerrado como en algún ejemplar de Baskunes (¿Pamplona?), ya fuera del ámbito estrictamente celtibérico, y coexisten con cascos de calota cerrada y carrilleras adelantadas, como el que, en el reverso de un As de Secaiza del 154 a. C., lleva el jinete con un halcón a su espalda que se ha convertido en el emblema de Segeda (Burillo 1999; fig. 3) (Fig. 15). Es precisamente este casco el que más se aproxima tipológicamente al de Aguilar de Anguita, pero la distancia cronológica entre ambos es de varios siglos.

Algunos autores interpretan que el hecho de que en la Península Ibérica los cascos representados o existentes dejen la cara despejada es una prueba de que la lucha era individual y no organizada en formación cerrada de tipo hoplítico. Formación en la que a los cascos cerrados, como los corintios, le acompañaban discos coraza y grebas de bronce (Gracia 2003: 207). Este modelo de casco, que perjudicaba la audición, se iría aligerando a la vez que el resto de la panoplia a partir del siglo V a. C. (Quesada 2003: 103). Sin contraponer esta opinión, consideramos muy interesante y significativa la observación de Baquedano y Cabré (1997: 267) apuntando que las imágenes de guerreros de las cerámicas numantinas y de Ocenilla, no llevan los cascos de tipo Montefortino que les corresponderían cronológicamente (siglo I a. C.), sino cascos con cimeras y crines, anteriores al siglo III a. C. que llevarían los príncipes «míticos». Esta apreciación, como acabamos de ver, es extrapolable al tipo de algunas monedas, lo que también intuía Lorrio (1995: 79), y nos recuerda que los jinetes del reverso de las monedas celtibéricas pueden ser héroes ecuestres mitificados, los antepasados comunes de la familia o clan (Almagro-Gorbea 1997: 216) (fig. 15). Esta visión estaría en consonancia con una propuesta de Quesada (2002: 39), según la cual las armas representadas en las esculturas de Porcuna o Elche y halladas en tumbas de Levante y la Meseta oriental, como esta de Aguilar de Anguita, son armas cercanas a las propias de un combate en formación cerrada, pero corresponderían a las de un combate «heroico» entre campeones aristócratas. Todo ello nos lleva a preguntarnos a través de qué narraciones orales o representaciones 


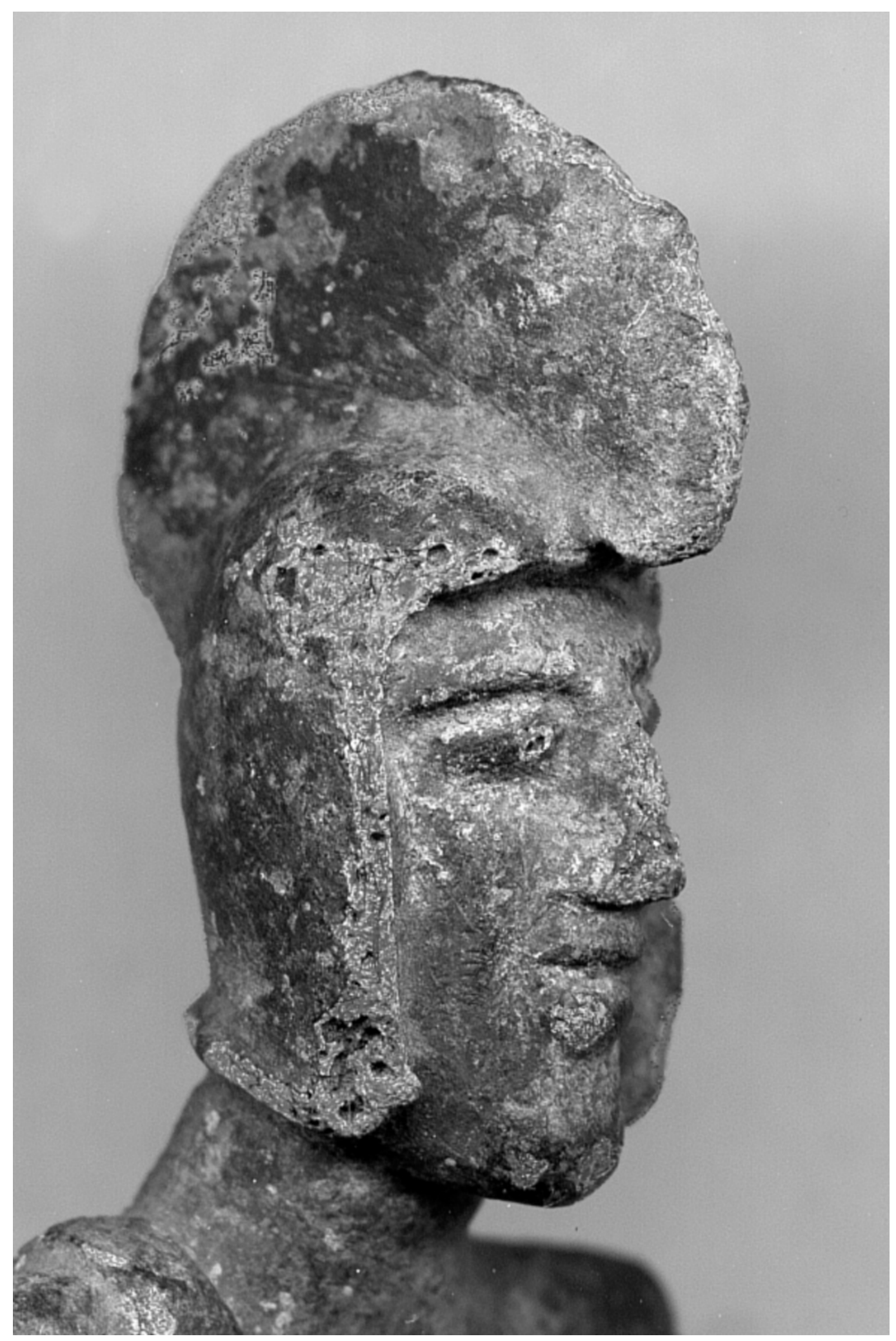

Fig. 13. Exvoto de Collado de los Jardines. No inv. M.A.N. 28614. 


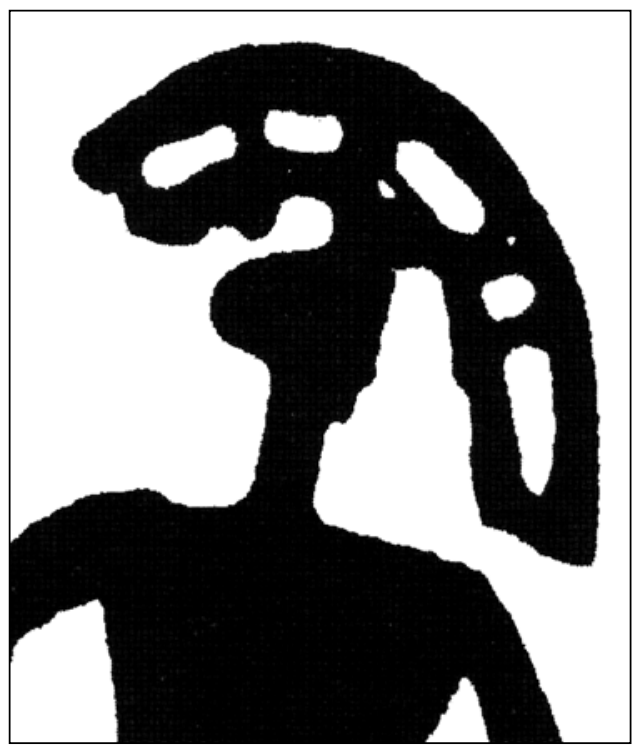

14. Detalle del guerrero del oinochoe de Ocenilla (Taracena 1932: 49, fig. 9).

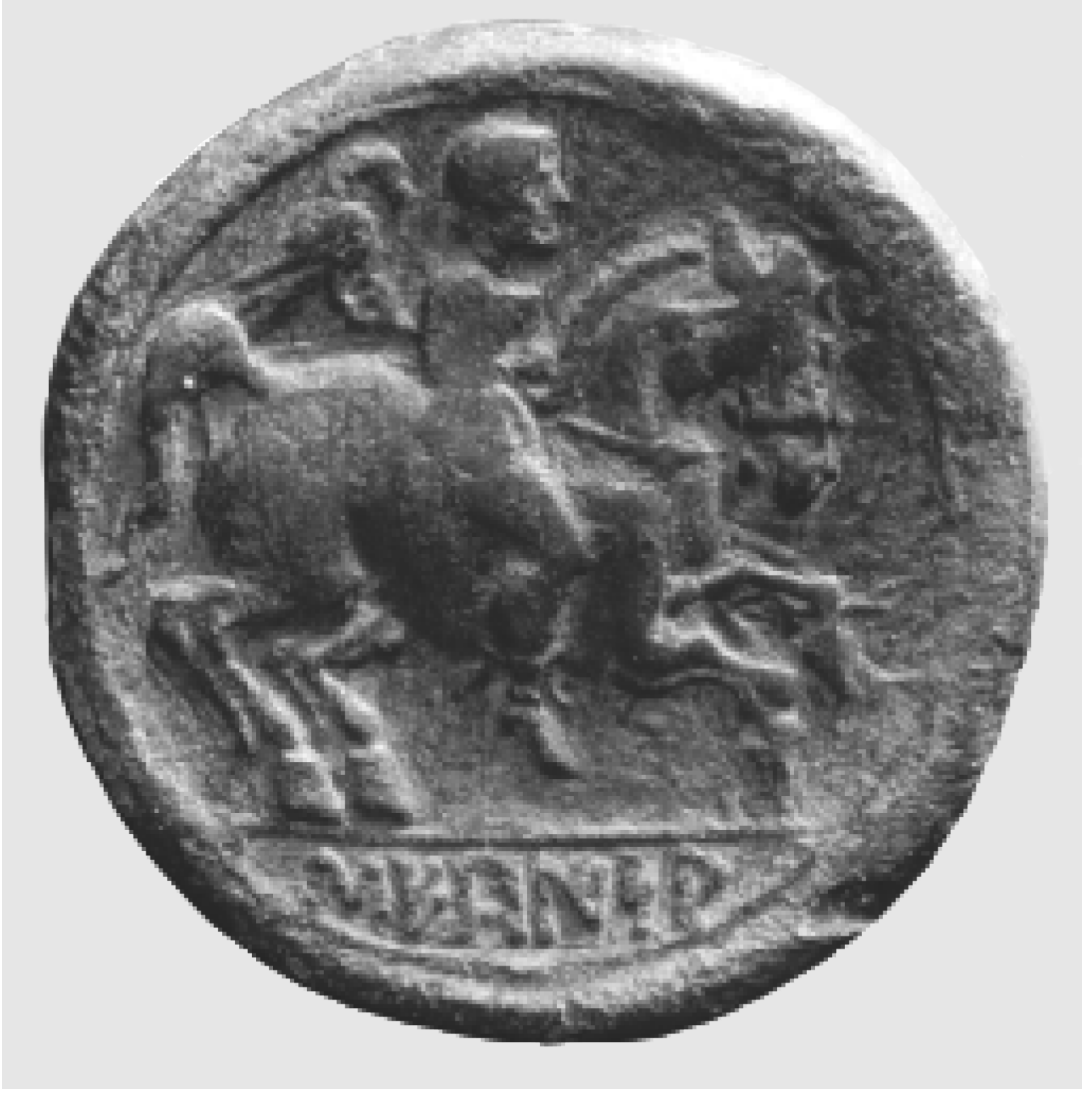

15. As de Secaiza (Segeda I), reverso. Foto Francisco Burillo. 
figurativas, que no nos han llegado, se mantuvo el conocimiento de unos tipos de cascos que ya no existirían en el momento de su representación iconográfica en los momentos finales del mundo celtibérico.

Otro aspecto a considerar es la decoración del casco de Aguilar de Anguita, consiste en una banda de hierro, con motivos grabados ya descritos, que lo contornearía y, donde actualmente falta, quedan huellas de la misma, incluso en la zona bajo los ojos. También debía de llevar algún disco cuya marca se conserva en el lado derecho en la carrillera. Es posible que alguno de los discos que se hallaron en la sepultura y se han considerado parte del atalaje de los caballos corresponda en realidad al casco y tengan una función equivalente a la decoración que se observa en los cascos cretenses o etruscos citados anteriormente.

La decoración bordeando el casco es una constante en los cascos mediterráneos. Los cascos corintios más modernos, están contorneados por grecas de roleos, ovas, puntos, etc. (Kunze-Schleif 1939: fig. 98, lám. 43) y hemos visto como los cascos cretenses también ofrecían una decoración en bandas en el guardanucas, aunque no en todo el contorno, y que en las representaciones iconográficas de cascos de la península itálica también se marca un reborde rodeando los cascos. En cuanto al motivo decorativo de la banda de hierro de Aguilar de Anguita, a base de ondas contrapuestas, creemos que tiene también origen mediterráneo, pero ya transformada y evolucionado. En la tabla de decoraciones de los cascos corintios de Olimpia no figura el motivo (Kunze VII, 93, fig. 43), pero el tema ' $a a^{\prime}$ ' podría ser un intermedio entre el de los roleos encadenados o los ochos continuos en sus múltiples variantes y este de Aguilar de Anguita consistente en ondas separadas entre sí y colocadas en líneas enfrentadas y descentradas. Este mismo tema, ya esquematizado, lo encontramos en cascos de tipos diversos, ya más relacionados con el continente europeo que con la zona mediterránea, citaremos como ejemplo uno de tipo alpino, tipo Negau, del siglo V a.C. del depósito de Negau-Obrat «Zenjak», Sr. Maribor (Eslovenia) donde este motivo aparece en la cresta y coexistiendo con aspas, espirales y palmetas en otras zonas del casco (Antike Helme 1988: 495, nº 88).

Por su parte, aunque no está clara, se adivina una línea de zig-zags junto a la de ondas en la banda de Aguilar de Anguita, que es uno de los temas más frecuente dentro de los elementos realizados en metal, bordeando pectorales, broches de cinturón o cañas de vainas de espadas.

Por todo lo expuesto, creemos que este casco de la necrópolis de Aguilar de Anguita tiene su origen en modelos etrusco-itálicos, lo mismo que los discos-coraza y el cuchillo con remate semicircular que aparecen en la misma tumba y que, podría englobar la relación de armas que son importadas o copiadas por su valor simbólico con un significado de poder y prestigio, tanto en el mundo ibérico como en el celtibérico y que autores como Kurtz proponen que se introdujeron a partir del triunfo de la alianza etrusco-púnica sobre los foceos en la batalla de Alalíe, en la segunda mitad del siglo VI a. C. y con especial incidencia a principios del siglo V a. C. (Kurtz 1991: 193).

\section{LOS CASCOS DE ALPANSEQUE, SORIA}

\section{Contexto}

La necrópolis del Val de Alpanseque, Soria fue excavada por el marqués de Cerralbo entre 1915 y 1916. Juan Cabré en el Catálogo Monumental de Soria ${ }^{16}$, describe la estructura general de las necrópolis en tres calles, numeradas de derecha a izquierda y restos de otras, a

16 Obra manuscrita que pudimos conultar gracias a la amabilidad de D. Juan Morán, nieto del autor, posteriormente fue entregada al CSIC y actualmente se encuentra en el IPHE para su restauración. 
su derecha, muy destrozadas. También describe los principales materiales de esas tumbas. En dos de las excavadas en 1915 y una de 1916 se encontraron restos de cascos.

1.- La primera sería la sepultura $n^{o} 12$ ? ( (sic) de la calle II, con lo que denomina «ajuar completo de un guerrero» en el que enumera una espada (de frontón) con un cuchillo y una punta de lanza y su regatón embutida en la vaina, unas planchas de bronce de bronce repujadas que recubrirían un escudo circular y varios fragmentos del mismo metal que por su forma y conexión serían de un casco y por último un bocado de caballo (con camas en artesa), una pieza agarrador que sería de la brida y una abrazadera con su argolla que pertenecería al escudo (Cabré 1917: lám XI). Este casco citado y fotografiado (Fig. 16), lamentablemente no está localizado y la imagen, borrosa, muestra un elevado número de pequeños fragmentos, de láminas muy finas de bronce, dispuestos en forma de $\mathrm{U}$ formando un borde moldurado. Es muy posible que dado el estado tan fragmentario en que se encontraba se haya traspapelado con el paso del tiempo. De hecho, el propio Cabré (1940: lám. III; 1942: fig. 5) cuando presenta el ajuar de esta sepultura por contener un escudo no dibuja ni menciona ningún fragmento del mencionado casco.

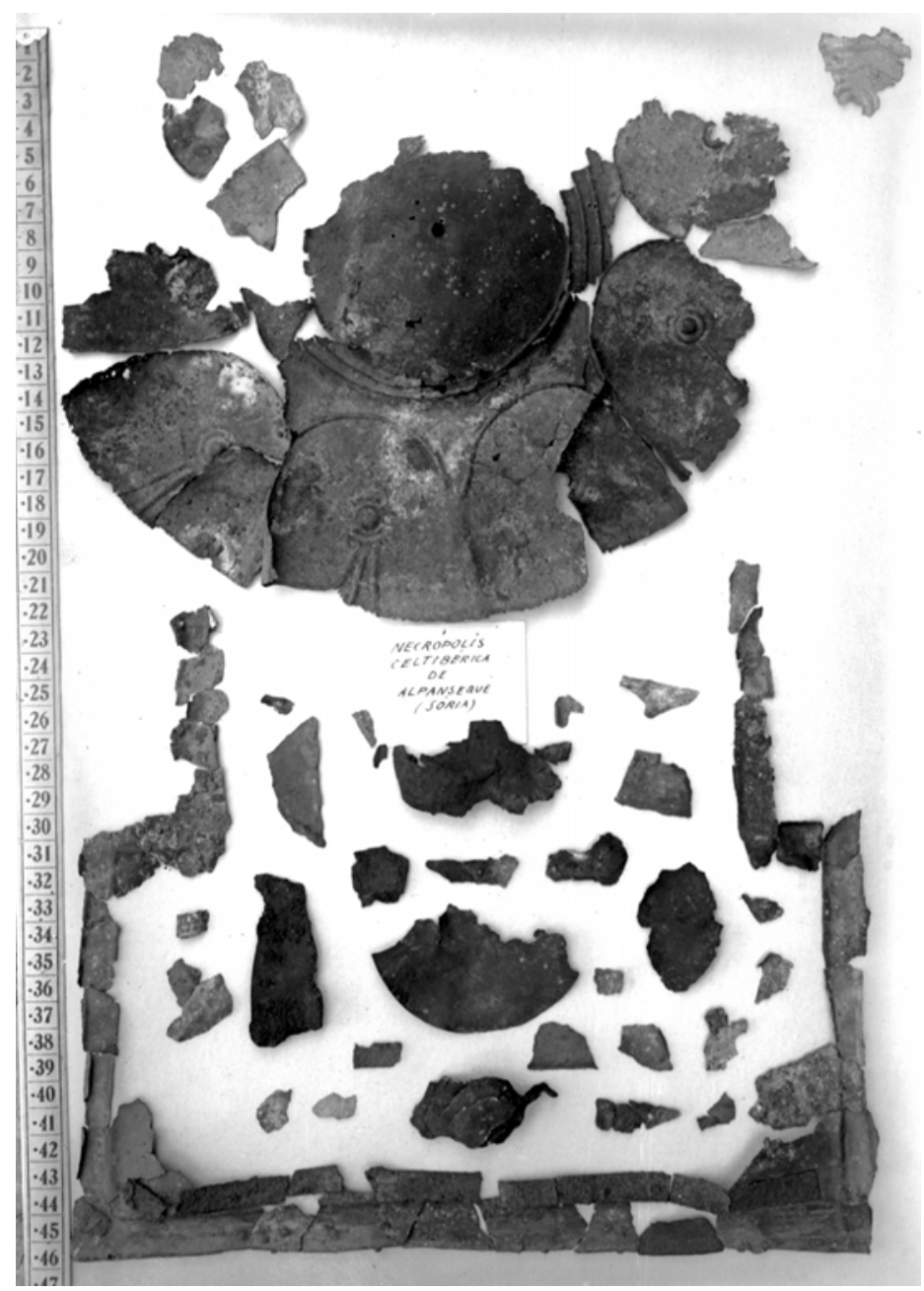

Fig. 16. Casco de la sepultura 12? de Alpanseque según Cabré 1917. Archivo Fotográfico Cabré. IPHE. Ministerio de Educación, Cultura y Deporte, nº 974. 
2.- Describe otra sepultura, la $n^{o} 20$ ? (sic), de la calle III, a la que denomina como de «guerrero» (Cabré 1917: lám XIII). Se compone de una espada de antenas en cuya vaina están metidas la lanza, el regatón y el cuchillo, de un casco de bronce con una franja sencilla de hierro (Fig. 17), de una pieza repujada de escudo, de dos abrazaderas con sus anillas de hierro, del escudo, de una cama recta de bocado y de una anilla de la brida del caballo. Como vemos un ajuar muy similar al anterior. En una nota añade que el casco puede asemejarse al de Sesto-Calende que publicaba Dechelette (1913) en la figura 275 del volumen 2 de su Manual y lo dibuja en pequeño tamaño, se trata de un casco de bronce, con casquete esférico reforzado con tiras remachadas y $\mathrm{ala}^{17}$. En 1940 y 1942 Cabré dibuja fragmentos de este casco dentro del ajuar de una tumba con escudo circular de bronce repujado y lo reconstruye idealmente (Cabré 1940: Lám. IV; 1942: fig. 6) (Fig. 18); Schüle republica esta documentación en 1969 y otros autores la revisan, más adelante, destacando que el casco se asocia a una espada de tipo «Aguilar de Anguita» o tipo III de Quesada y a un umbo de escudo circular broncíneo decorado, de la fase $1^{\mathrm{a}}$ de Cabré, conocido como «tipo Alpanseque», y, recientemente, denominado tachón macizo del tipo IA por Quesada. Su cronología se sitúa entre el siglo V y el IV a. C. y pertenecería a la Subfase IIA1 del Alto Jalón (Cabré 1940: 59, lám. IV; 1942: 198; Lorrio 1997: 167; Quesada 1997: 552).

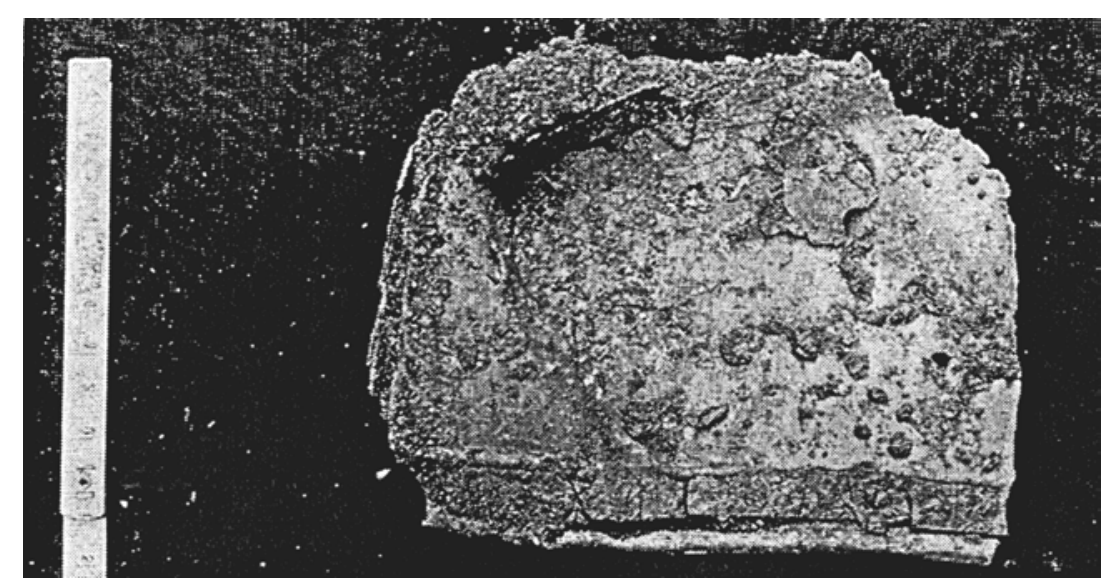

Fig. 17. Casco de la sepultura 20? de Alpanseque según Cabré 1917.

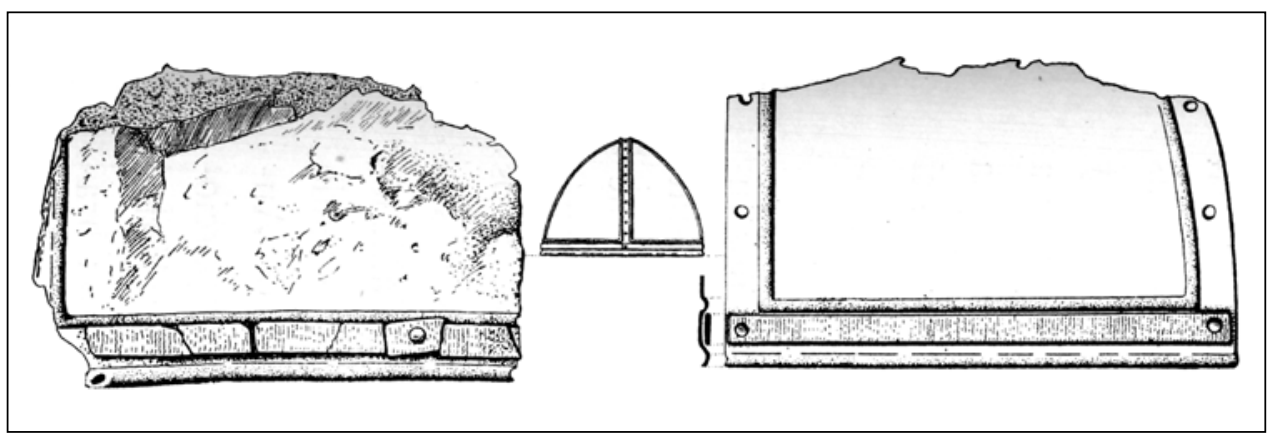

Fig. 18. Casco de la sepultura 20? de Alpanseque según Cabré 1940.

17 La tumba es de incineración hallada en las cercanías de Milán y contenía además dos cnémides y una sítula de bronce y una espada de antenas entre otros ricos objetos (Dechelette 1913: 720, fig. 275). El casco pertenece al denominados tipo alpino. 
3.- Finalmente, en la lámina XVII del Catálogo Monumental de Soria describe otra sepultura de un guerrero, excavada esta vez en 1916, sin número y sin calle (por el plano de situación suponemos que estaría a la derecha de la denominada calle 1, excavada en 1915, ya que había otras tres calles en dirección Este, excavadas sólo parcialmente debido a su deterioro). Esta tumba contenía un pequeño puñal de empuñadura de frontón, lanza, cuchillo, abrazaderas, ómfalo y anillas de un escudo, todo ello de hierro, y de un casco repujado de bronce (Fig. 21). La fotografía de este casco, nos muestra un casco aplastado, que Cabré fue capaz de reconstruir, dándole una forma cónica sobre el papel, decorada con círculos radiados (Fig. 22), junto a un escudo de radios de hierro y las armas y utensilios citadas (Cabré 1940: 61, lám. VI y 1942: fig. 7). Este autor consideraba que este casco, al igual que los otros de Alpanseque y el del Almaluez del que luego hablaremos, era muestra del máximo florecimiento de la industria de los bronces repujados, desarrollada durante el siglo IV a. C. (Cabré 1942: 198). Schüle, al igual que los ejemplares anteriores, lo republicó y el resto de los autores también lo revisa o menciona con notas bibliográficas en la misma línea cronológica que el casco de la sepultura 20 ?

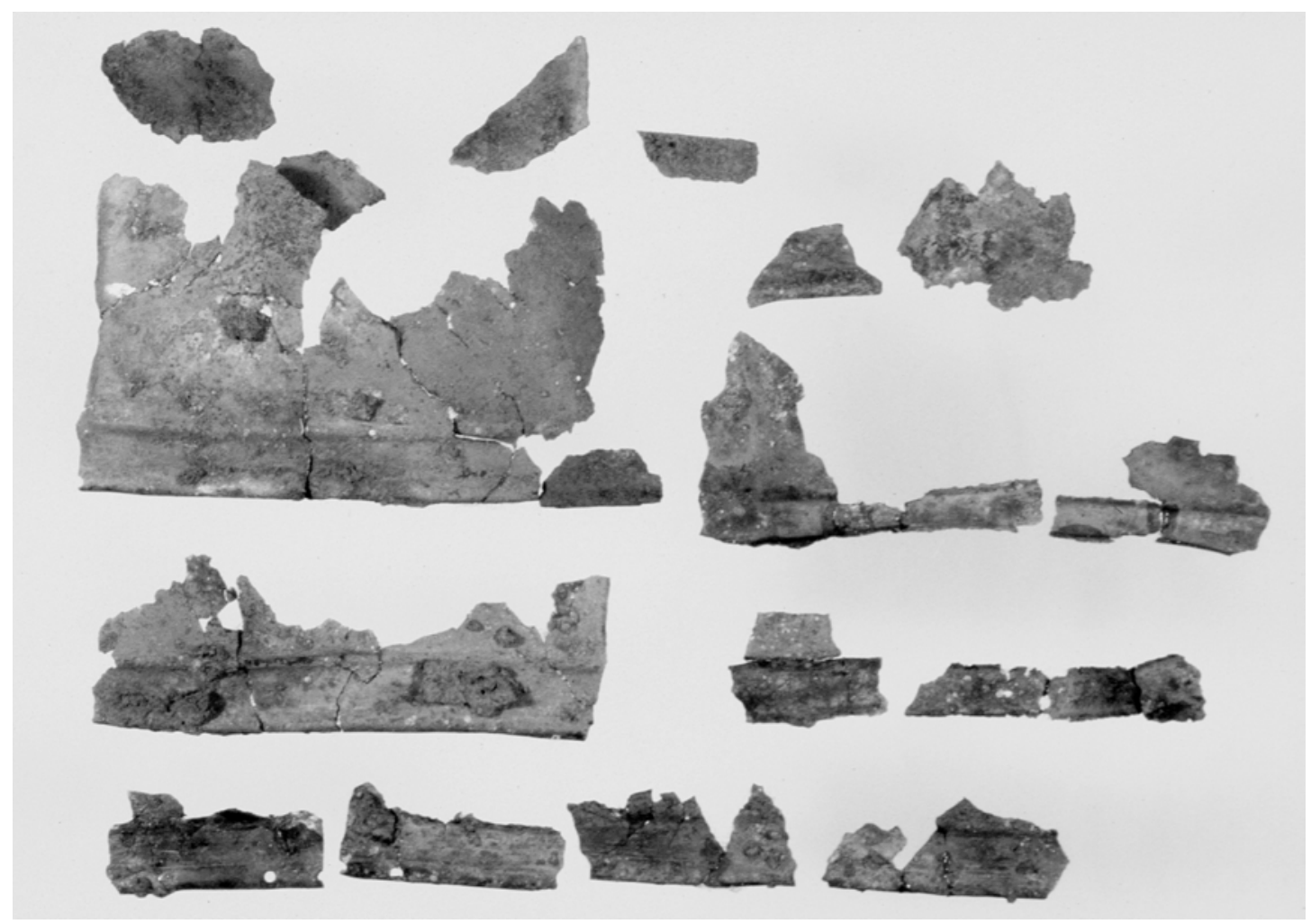

Fig. 19. Casco de la sepultura 20? de Alpanseque, estado actual. Foto M.A.N Ángel Rodríguez.

La tumba fue denominada «sepultura A de Alpanseque» por Schüle, quien confirmó la relación de la decoración del casco con la de los pectorales de Aguilar de Anguita y la coraza de «Les Humbries» de Calaceite, Teruel, propuesta por Cabré (Schüle1969: 117). Otros autores destacan de la tumba la asociación del casco a un puñal de frontón, de datación alta y un tachón grande de un umbo de escudo radial, de hierro, de la fase $1^{\mathrm{a}}$, variante A de Cabré o IIA de Quesada (Cabré 1940: lám. VI, Lorrio 1997: 166; Quesada 1997: 552). 


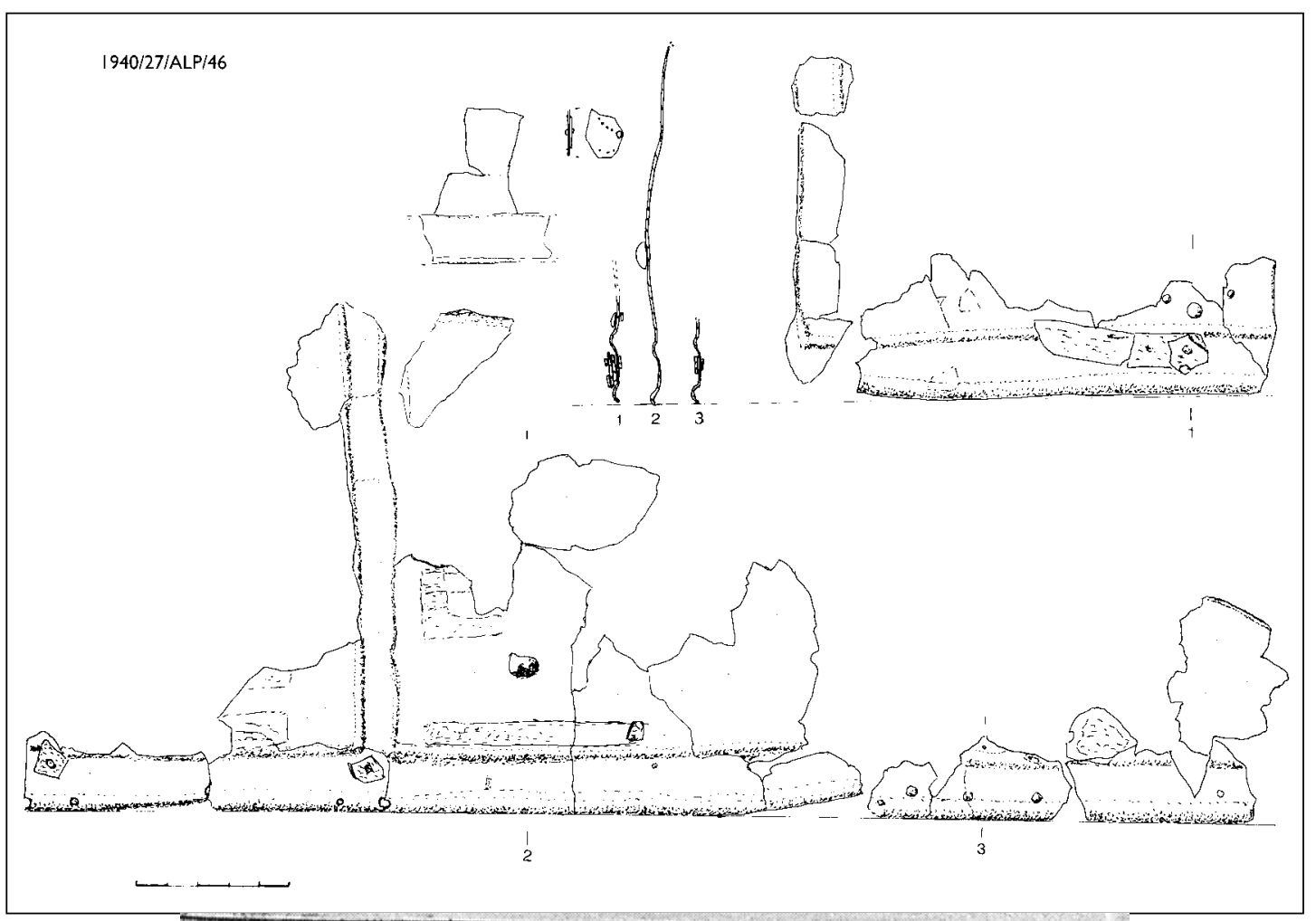

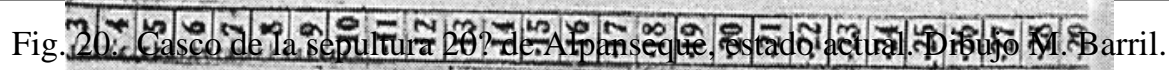

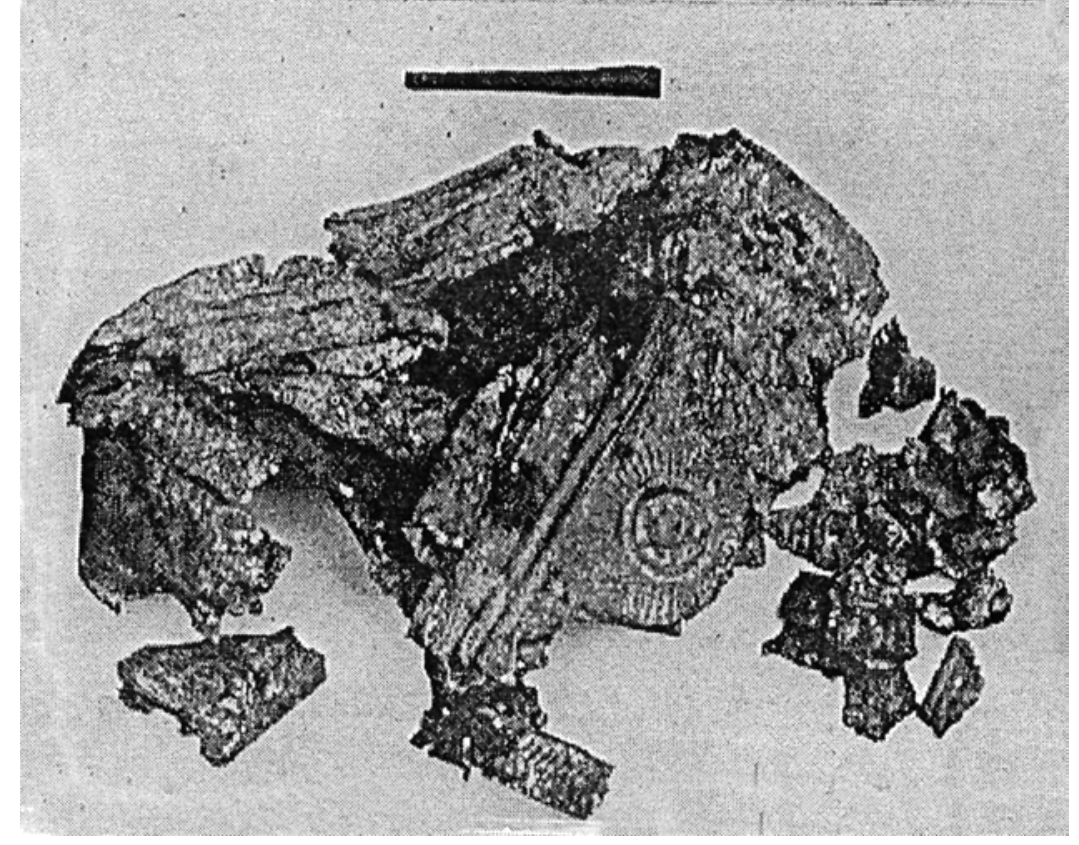

Fig. 21a. Casco de la sepultura A de Alpanseque según Cabré 1917. 


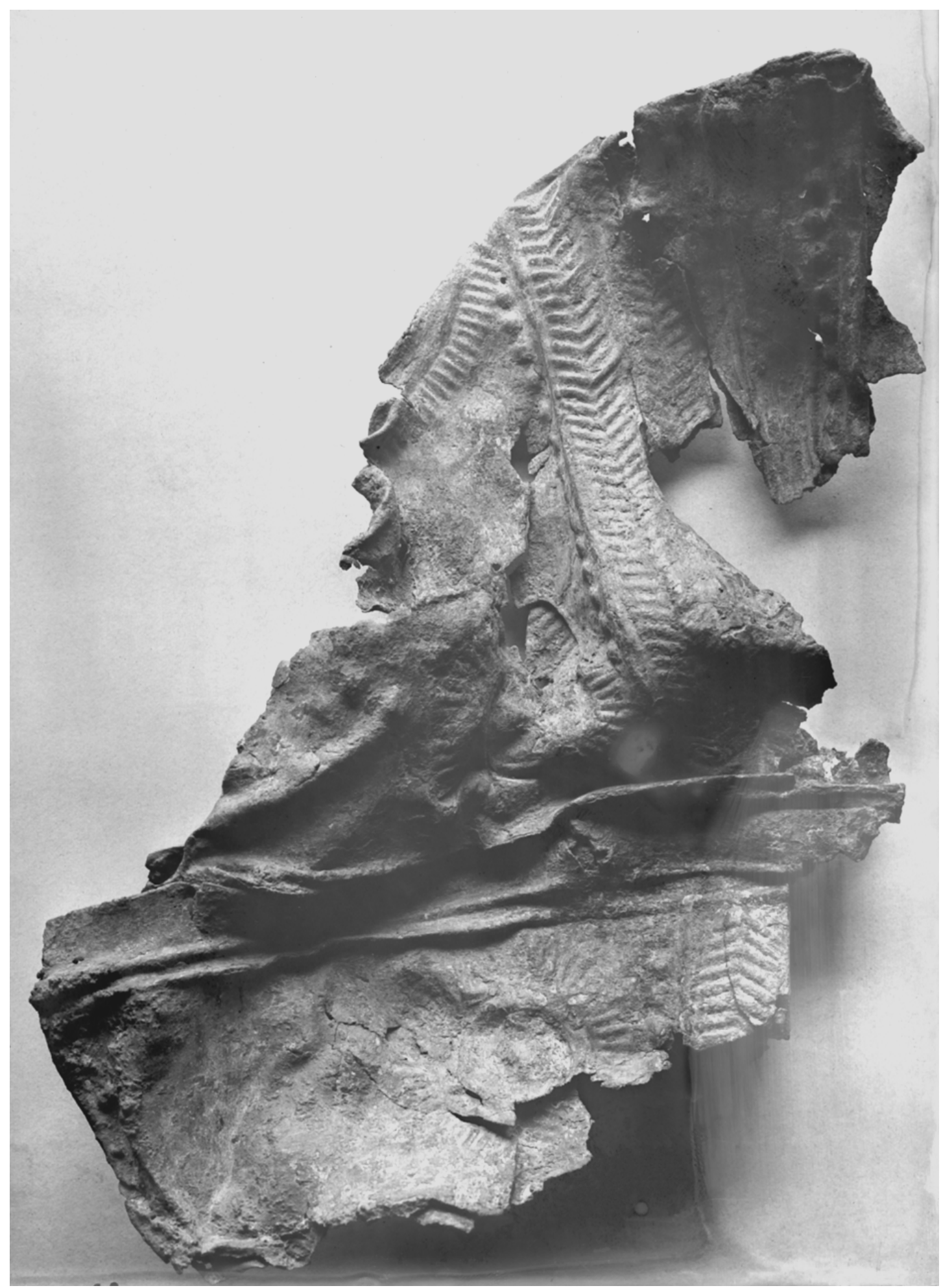

Fig. 21b. Archivo fotográfico de Cabré. IPHE. Ministerio de Educación y Deporte, nº 878. 
Los dos últimos cascos se han convertido en «cascos tipo Alpanseque» en la bibliografía peninsular posterior, definidos como «Cascos de calota ojival formada por cuatro láminas de bronce aproximadamente triangulares unidas por tiras de hierro con remaches», una técnica sencilla, que Quesada data en el siglo V a.C. (1997, $\mathrm{n}^{\circ} 4079$ y 4081, fig. 315) y paraleliza con uno de Almaluez, Soria, del que hablaremos más adelante y que se encuentra muy deshecho (Domingo 1982: lám. IV.1). Sin embargo, y como demostraremos, creemos que el casco de la 'sepultura 20?', aunque pueda corresponder a esa forma tiene otra ejecución y debemos, por tanto, diferenciar entre morfología y apariencia final y realización.

\section{CASCO DE LA SEPULTURA 20? DE LA CALLE III}

\section{Descripción (Fig. 19 y 20)}

Está inventariado con el número 1940/27/Alp/46, y sólo se conservan fragmentos algunos de los cuales han podido unirse formando dos trozos con borde inferior y sin posibilidad de darle curvatura adecuada.

El primero mide $16,5 \mathrm{~cm}$. de alto, $27,5 \mathrm{~cm}$. de longitud y $1 \mathrm{~mm}$ de grosor máximo; es una lámina lisa dividida en dos partes por una banda transversal enmarcada por dos nervios repujados; la base está también formada por un reborde a modo de nervio, una banda lisa sobre la que queda algún resto de una cinta de hierro y otro nervio repujado; conserva un grueso remache, perceptible únicamente al exterior actualmente; también se aprecia sobre el nervio superior restos de otra laminita de hierro y huellas de una tira de hierro horizontal y restos de otra en la parte superior del fragmento. El segundo fragmento mide $4,4 \mathrm{~cm}$. de alto y $13 \mathrm{~cm}$. de longitud, con menos de $1 \mathrm{~mm}$. de grosor, pertenece igualmente al borde inferior del casco y presenta restos de dos láminas de hierro dentro de la franja enmarcada por los dos nervios repujados; ambas láminas tienen superpuestas su inicio y final respectivamente, y se unen al casco mediante remaches. Se conservan otros fragmentos del mismo tipo, en su mayoría corresponden a un borde con pequeñas perforaciones para remaches y destacamos una fina lámina que conserva la escuadra que forma el nervio repujado horizontal del borde con el que enmarca la banda vertical transversal, sin que podamos unirlos con total certeza a los otros fragmentos.

La totalidad de los bordes del casco miden $56,5 \mathrm{~cm}$., lo que proporcionaría un diámetro de $18 \mathrm{~cm}$., unas medidas que podría ser muy cercana a la real, aunque no somos por ahora capaces de situar correctamente todos los fragmentos de ese borde que se han conservado, independientemente de que falta gran parte de la calota. Hay otro fragmento de banda de $4 \mathrm{~cm}$. de longitud, que por su grueso, algo inferior al milímetro del borde, y algo superior al de las bandas verticales, no nos atrevemos a sumarlo ni a la medida del contorno ni a la de la altura.

El conjunto de los fragmentos creemos que permite visualizar una pieza con un borde formado por una banda enmarcada por dos nervios repujados y compartimentada por al menos dos bandas transversales de similares características. Todas estas bandas albergarían cintas de hierro, destacando que en la cercana al borde, la cinta de este material está sujeta mediante remaches. Otra cinta horizontal discurriría sobre esta banda según las huellas que detectamos, y en otros puntos, se aprecian más huellas de láminas superpuestas y perdidas, que tendrían función decorativa y tal vez también de refuerzo. Su estado no permite determinar con exactitud su tamaño y forma.

Como hemos señalado el dibujo que ofreció Cabré no se corresponden exactamente con los restos que se conservan actualmente, ya que él reconstruye un casco de cuatro láminas superpuestas y dibuja dos láminas incompletas, una casi triangular con dos solapas laterales 


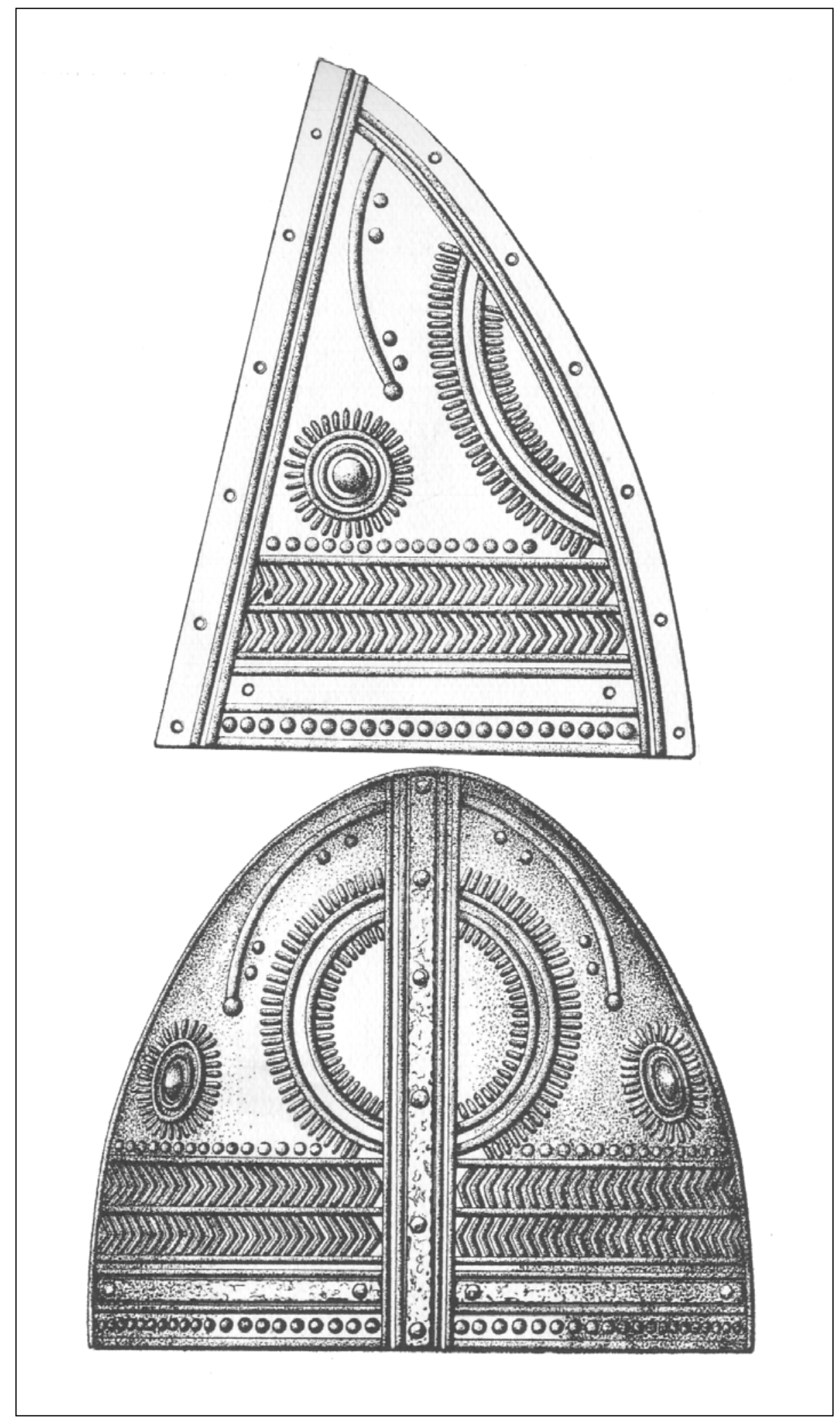

Fig. 22. Casco de la sepultura A de Alpanseque según Cabré 1940. 
con perforaciones para remaches, que como hemos señalado no identificamos, y otra lámina en la que señala una huella en forma de L invertida en su parte superior que bien pudiera corresponder a la de una banda decorativa, relacionada con la que hemos señalado anteriormente, aunque en otra posición. Se conserva aún el casco con restos de la tierra roja en que se halló.

\section{Análisis técnico}

Al igual que el casco de Aguilar de Anguita se trata de un casco realizado sobre una fina lámina de bronce binario que D. Salvador Rovira analiza en el apéndice a este trabajo.

Como ya se ha indicado, desde Cabré se ha interpretado este casco como de tipo cónico, formado por varias láminas de bronce remachadas entre sí y con algunas tiras de hierro como refuerzo. Sin embargo, la unión de fragmentos que proponemos indica que estaba realizado en una sola pieza compartimentada por al menos dos bandas transversales enmarcadas por nervios repujados, que albergarían cintas de hierro.

\section{CASCO DE LA DENOMINADA «SEPULTURA A»}

\section{Descripción (Fig. 23 y 24)}

Se conserva en el M.A.N. inventariado como 1940/27/Alp/51, consta de un gran fragmento muy doblado y aplastado que mide $15,7 \mathrm{~cm}$. de alto y $20,5 \mathrm{~cm}$. de longitud el fragmento mayor que tiene un grosor total de unos seis $\mathrm{cm}$. resultado de la superposición de dobleces de la lámina, que tiene un grosor inferior a $1 \mathrm{~mm}$. Hay otros fragmentos de diversos tamaños, algunos de los cuales dibujamos, señalando que dos de ellos, uno de 7,8 x $10 \mathrm{~cm}$. y que conserva la solapa remachada a la solapa de la lámina a la que se unía (fig. $23 \mathrm{c}$ ) y otro, menor, se pueden unir en el reverso del gran fragmento deformado, pero que en su reciente restauración ${ }^{18}$ se ha preferido no hacerlo para permitir la observación de la superficie que taparía, una pestaña con cuatro perforaciones, y facilitar su estudio.

Como dibuja Cabré, el casco estaría realizado en cuatro láminas casi triangulares que se solapan formando una franja vertical enmarcada por dobles nervios repujados (correspondiendo los nervios a ambas láminas) y que se unen entre sí verticalmente mediante gruesos remaches de hierro. El interior de las láminas contiene una abundante decoración de motivos repujados: En la base, conforma el borde inferior un doble nervio horizontal; sobre él una línea de gruesos puntos; sobre éstos otro nervio horizontal y a continuación una banda horizontal, en cuyo reverso conserva tramos de una lámina superpuesta de hierro con los bordes punteados, posiblemente para ajustarse más al bronce. A continuación otro nervio horizontal y sobre él dos franjas de espigas >> continuas enmarcadas por nervios. Sobre éstas, otra línea de gruesos puntos que se entrecorta por la presencia de círculos radiados de un diámetro de $4,2 \mathrm{~cm}$. y semicircunferencias doblemente radiadas; esta línea de puntos en el reverso se cubre con otra tira de hierro superpuesta con los bordes punteados. En la calota, en una de las láminas, sobre un círculo radiado, una forma plástica incompleta en forma de arco de circunferencia, rematado en botón repujado y al lado dos puntos. En esta zona observamos una mancha de hierro rectangular a ambos lados de una de las roturas, su disposición nos hace plantearnos que se trata de una grieta antigua que se reparó con una plaquita de hierro perdida.

18 Ha sido restaurado en el Departamento de Conservación y Restauración del M.A.N. por Dña. Silvia Viana restauradora contratada con cargo a los Convenios INEM-Ministerio de Cultura. 


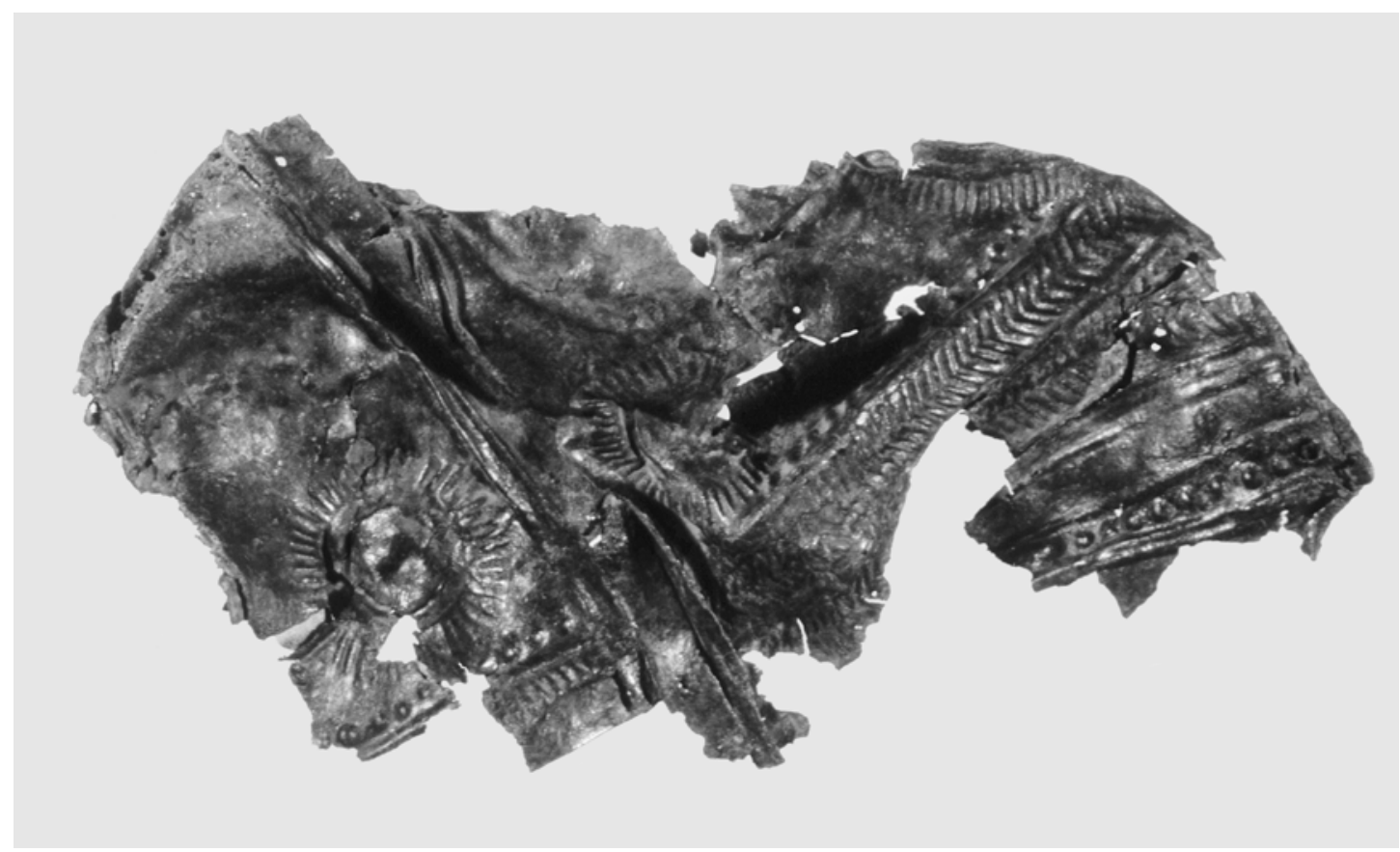

Fig. 23 a. Anverso.

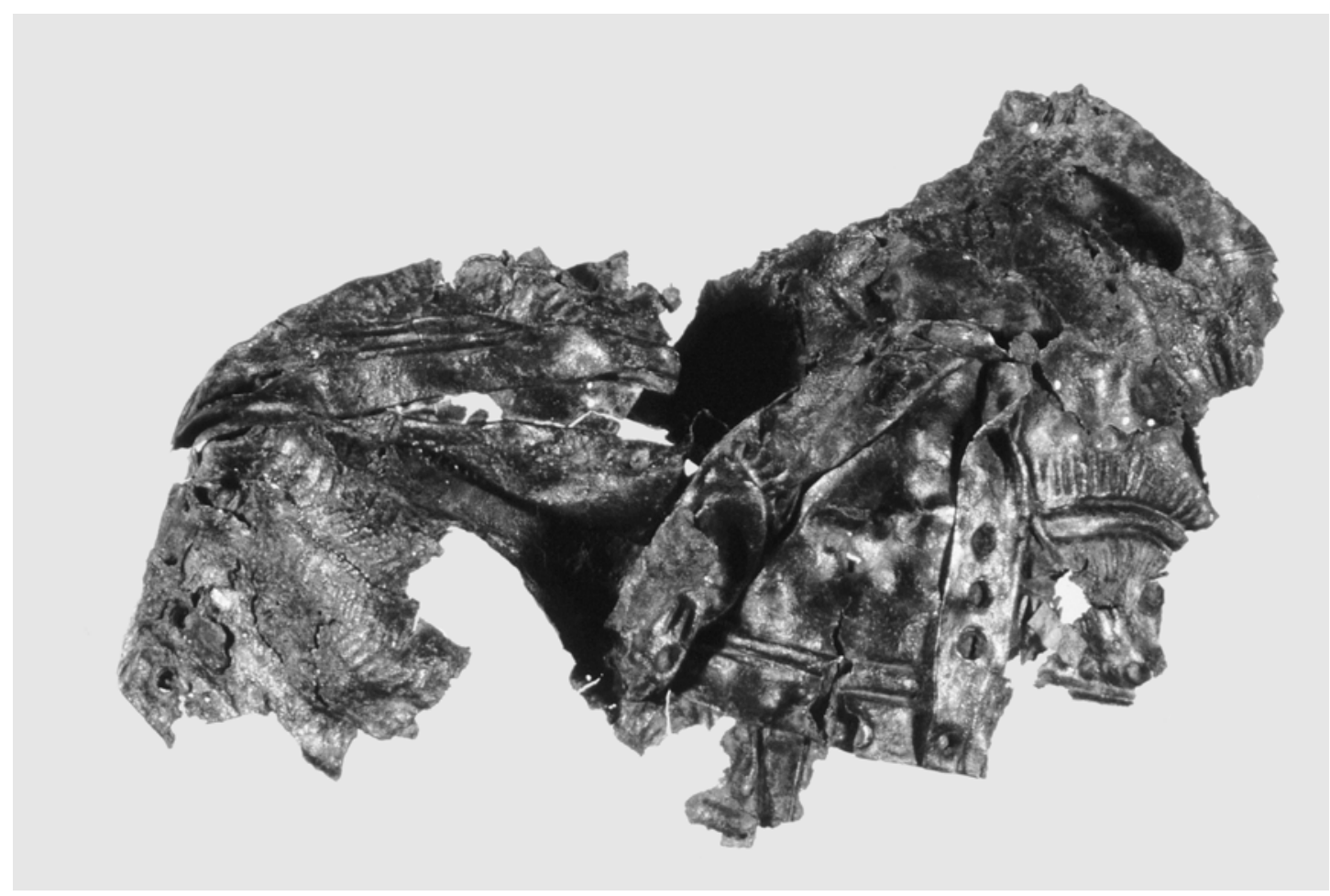

23 b. Reverso.

Fig. 23. Casco de la sepultura A de Alpanseque, estado actual. Foto M.A.N Ángel Rodríguez. 


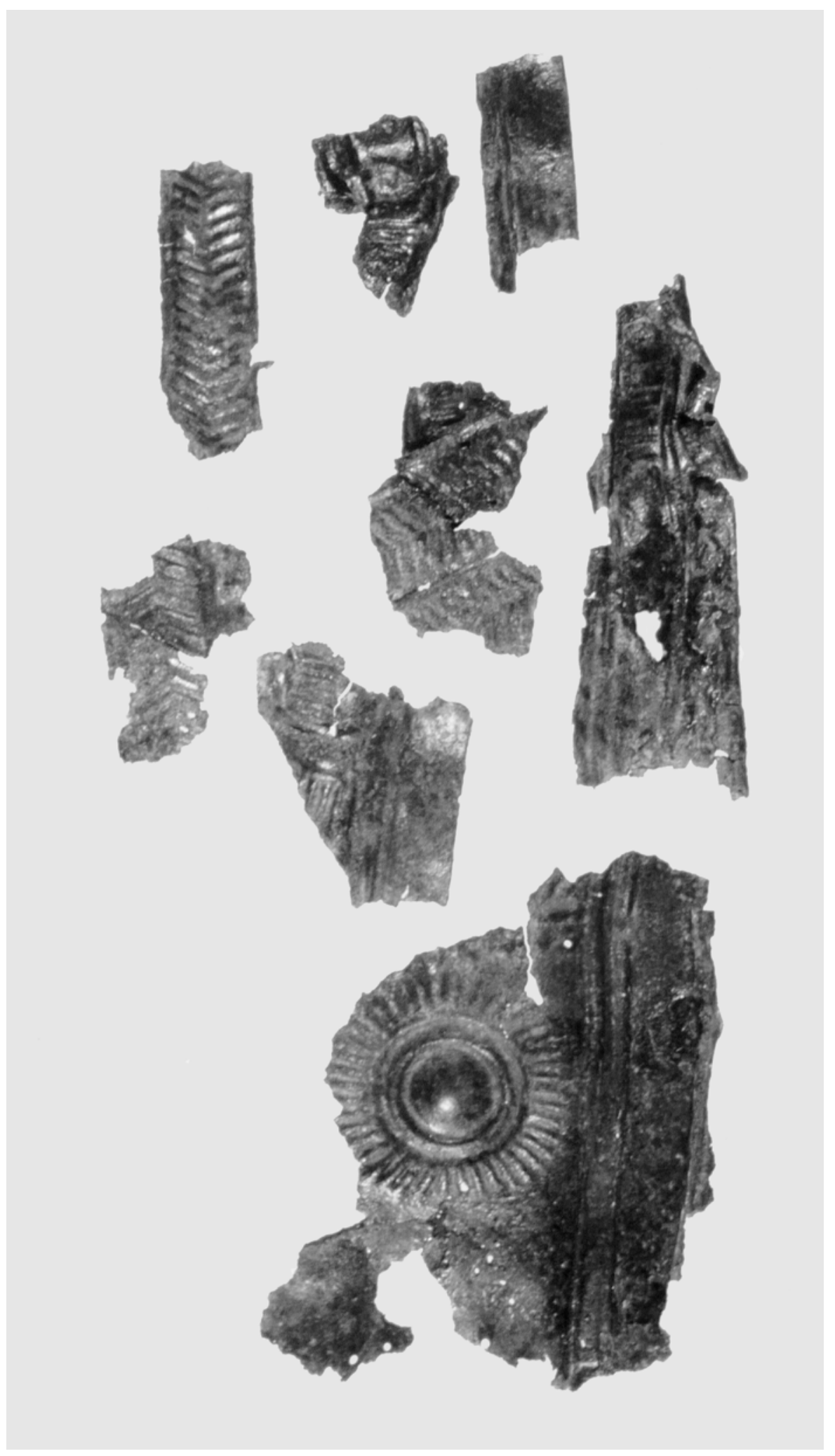

Fig. 23 c. fragmentos sueltos. 


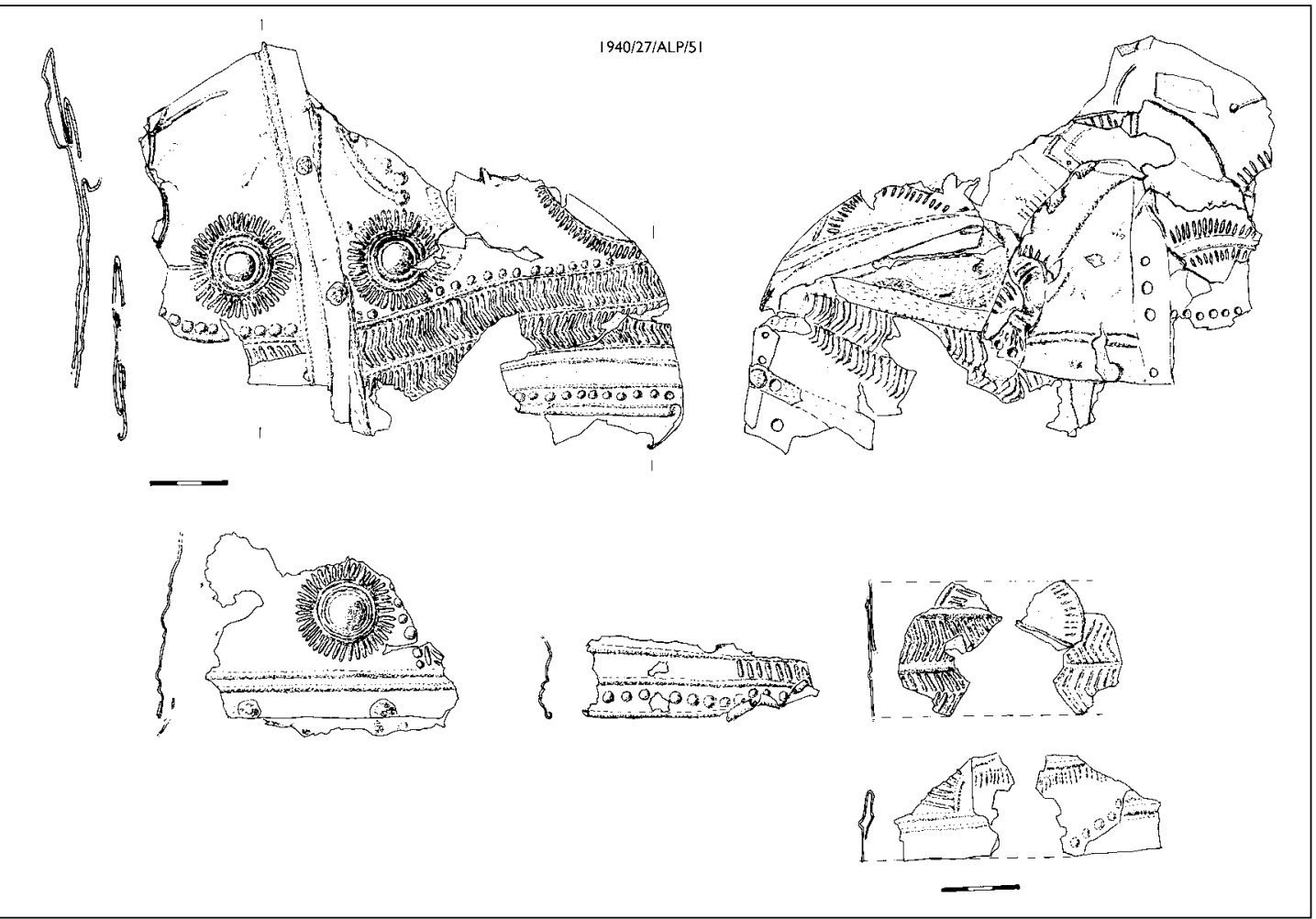

Fig. 24. Casco de la sepultura A de Alpanseque, estado actual. Dibujo M. Barril.

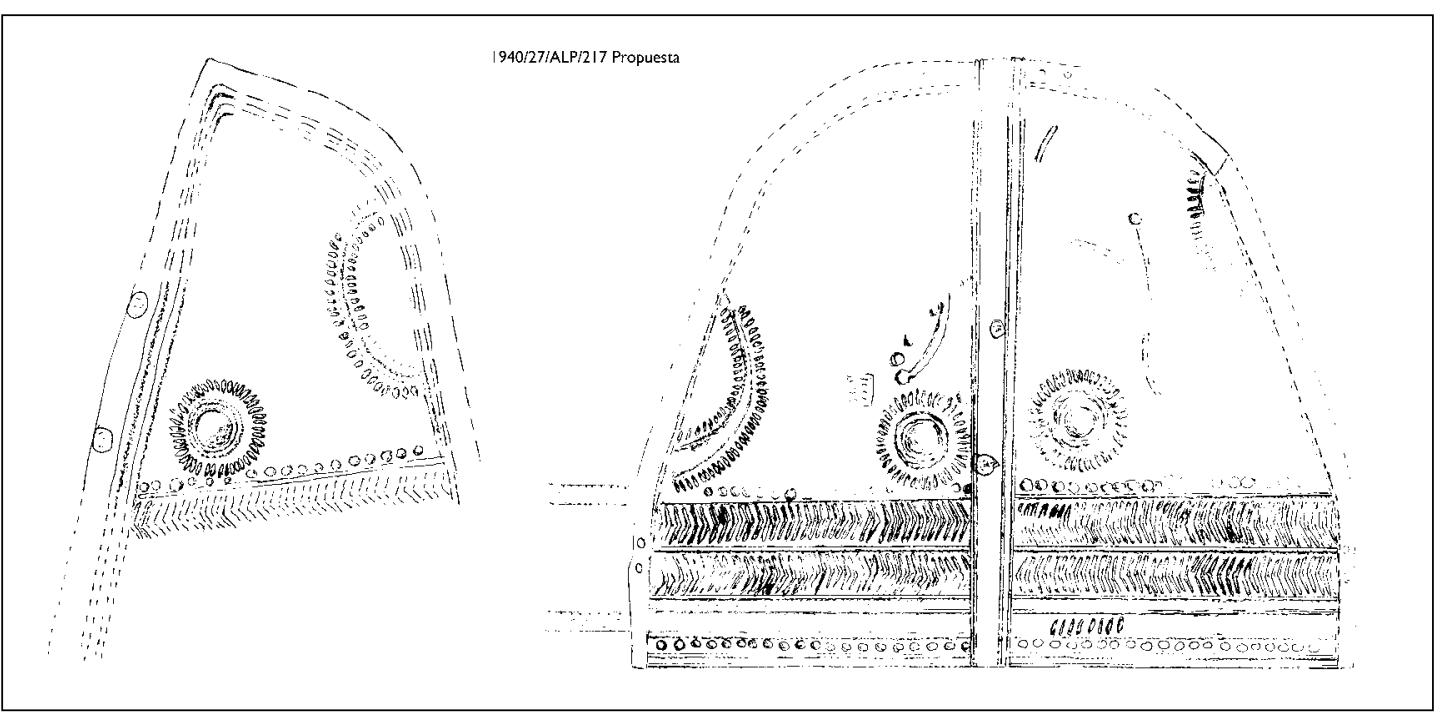

Fig. 25. Casco de la sepultura A de Alpanseque. Propuesta de interpretación M. Barril.

Cabré reconstruía con simetría todas las láminas, pero actualmente no somos capaces de deducir completa ninguna de ellas, y el resultado de lo que observamos difiere algo de la propuesta de este autor que seguramente tuvo más elementos que los que nos han llegado. La 
reconstrucción ideal sobre el papel nos proporciona una pieza de entre 52 y $55 \mathrm{~cm}$. de contorno en la base y unos $21 \mathrm{~cm}$. de alto, aunque el vértice es hipotético (Fig. 25).

Señalar, a nivel tecnológico, que en la línea de puntos situada junto al reborde inferior, el situado más a la derecha, en el anverso, es, en realidad, una perforación donde iría un remache.

Hay otro fragmento interesante que pertenece a un borde de un único nervio horizontal; sobre él una línea de puntos repujados, otro nervio y, a continuación, una franja horizontal, que lleva en un tramo decoración de cortas líneas paralelas oblicuas. Este motivo no habría sido identificado por Cabré quizás por tratarse de un fragmento que ha sido reconstruido recientemente por la restauradora y que situamos en la base del casco, donde la banda horizontal situada sobre la de puntos no sería lisa en las cuatro láminas que suponemos, sino que al menos en una de ellas habría una alternancias metopada de líneas oblicuas y espacios lisos.

En el reverso se aprecian las ya citadas tiras de hierro que reforzarían el casco y que presentan en algunos tramos de su borde pequeños puntos repujados y las perforaciones que situadas en las solapas permitirían su unión a otra lámina.

\section{Análisis técnico}

Al igual que los cascos anteriores D. Salvador Rovira comenta su composición de bronce binario y éste si se encuentra realizado en cuatro láminas de bronce remachadas entre sí mediante clavos de bronce y de hierro y reforzada con cintas interiores de hierro en sentido horizontal. Destacando la posibilidad de que hubiera sido reparado en un momento antiguo.

\section{CAsco de la sepultura 12? De AlpanseQue}

El tercer casco de Alpanseque, que según el Catálogo Monumental de Soria habría sido hallado en la sepultura 12?, ya se ha indicado que no se conserva documentado físicamente, pero constaría de un borde similar a los descritos hasta ahora: una banda lisa enmarcada por al menos dos nervios, con una cinta de hierro, estaría realizado en una sola pieza, y no descartamos que pueda estar mezclado con los fragmentos del casco de la sepultura 20.

\section{Adscripción tipológica de los cascos de Alpanseque}

Al igual que ocurría con el casco de Aguilar de Anguita, no tenemos paralelos exactos, para los cascos de Alpanseque, pero si emparentados. Son cascos cónicos o semiesféricos, compuestos de una o varias piezas ensambladas sobre un soporte de cuero u otra materia orgánica, y que, en ocasiones, llevan un botón central, superpuesto o incluido, del que no tenemos huellas visibles entre los restos conservados. Es una forma que evoluciona desde el Bronce Final y que en la Península Ibérica vemos representada iconográficamente similar en algunas de las estelas del Sudoeste peninsular, de entre las que seleccionamos la representación de la de Camino de la Sierra de Zarza de Montánchez, Cáceres (Galán 1993: 98, nº 25, fig. 22), por tratarse de un casco sin cresta, ni cuernos, pero con la misma forma de casquete cónico que las que presentan esos aditamentos. Feugère piensa que los cascos cónicos simples coinciden en el tiempo con los de cresta, que serían los de aparato y que a partir del siglo VIII se simplifican (Feugère 1994: 12). La tabla de tipos durante el Bronce Final y los primeros momentos de la Edad del Hierro así parecen confirmarlos, los cascos de este momento, en toda Europa, y en especial en la Península Itálica son cascos cónico o semiesféricos, con un botón o remate en su vértice y que en el siglo VIII a.C. se decoran profusamente con puntos, círculos, zig-zags, aspas y otros motivos (Schauer 1988: 193: Hase 1988: Abb.1). 
Las crestas de bronce ${ }^{19}$, se transformarán durante la edad del Hierro en cimeras orgánicas, de crines de caballo.

En momentos más avanzados cronológicamente los paralelos más cercanos, tanto formales como decorativos, los encontramos dentro de la Península Itálica, en particular en las culturas etrusca o picena. En algunas escenas de éstas últimas aparecen representados guerreros que, como ya hemos indicado anteriormente, llevan unos un casco del tipo al que suponemos pertenece el de Aguilar de Anguita, y otros de este modelo cónico, como en los pectorales discoidales de Raspagnano (Stary 1981; taf. 59.1 y 2) (Fig. 12). Dentro de la Península Ibérica destacamos el casco semiesférico, algo peraltado, de Coves de Vinromá, Castellón (Gusi 2001: 177) y que conservado en el Instituto de Valencia de Don Juan, antes se hacia proceder de Caudete de las Fuentes, Valencia ${ }^{20}$ (Blázquez 1960: 379), se trata de un casco que actualmente se data en el siglo VIII a. C. ${ }^{21}$, de plata, realizado en una sola pieza y que está todo cubierto de bullones o botones repujados que dejan en reserva, sobre la frente dos cuernos, ligeramente cincelados, y para el que siguen observándose influencias técnicas y estilísticas centroeuropeas y del norte de Italia (Gusi 2001: 177) y, con cronología más reciente, del IV a. C., podemos señalar la representación del casco cónico con borde sogueado que lleva la cabeza representada en el pie de la fíbula de Drieves, Guadalajara (Barril 2002: 203), o el que lleva el guerrero representado en un aplique de bronce, procedente de Atxa (Vitoria-Gasteiz) y que porta también un pectoral de discos, este casco, apenas esbozado, parece un casquete cónico con una espectacular cimera en forma de prótomo de caballo (Baquedano y Cabré 1997: 267), y que confirmaría la costumbre de muchos pueblos de decorar con crestas de diversos animales y que Silio Itálico (Pun. III, 388-389) refiere para las gentes de Uxama y Diodoro (V, 30, 2) para los galos (Quesada 1997: 569).

Los cascos de tipo cónico son por tanto antiguos y van modificándose con el paso del tiempo, pero llegaron a coincidir en espacio y época con los de tipo corintio y los etruscos (Schauer 1988: Abb. 9).

Estos de Alpanseque llevan delgadas láminas de hierro como elemento decorativo y de refuerzo, tanto en el interior como en el exterior, lo que los sitúa cronológicamente en un momento algo más avanzado que los realizados sólo en bronce.

Dado el estado en que se encuentran, no es posible determinar la situación de todas las perforaciones, pero nos hemos planteado que si algunas estuviesen perfectamente enfrentadas podrían tener la función de sujetar un cordón o cinta estrecha para atarlo bajo la barbilla, o un trozo de cuero del que partiesen; propuesta que realizamos a partir de representaciones iconográficas como la observada en los cascos semiesféricos de los jinetes grabados sobre la vaina de una espada de tipo La Tène I, procedente de la sepultura 994, de la necrópolis de Hallstatt, Austria (Megaw 1989: 81) que llevan un fino borboquejo.

Es muy probable que estos cascos en su interior llevasen un casquete de cuero o un capacete de materia orgánica ${ }^{22}$, para acoplarlo mejor a la cabeza y dar consistencia a una lámina de gran delgadez. De hechos algunos autores consideran que la utilidad de este tipo de casco de bronce sería prácticamente nula y, sólo tendrían un significado social de alto estatus, a la vez que piensan que uno de cuero sería más práctico a efectos de protección (Quesada 1997:

19 Cascos con cresta de bronce se encuentran, datados entre el siglo IX y VIII a. C en el depósito de armas de la Ría de Huelva (Ruiz-Gálvez 1995: 217, lám. 19), y también en Tarquinia, en Italia, o en Zavadintsy, en Ucrania, es decir ligados a cultura del Bronce Final Atlántico, villanoviano o hallstáttico (Aigner 1992: 160; Pallottino 1992: 250, nº 251 y 252).

20 Agradecemos a Dña. Cristina Partearroyo, conservadora del Instituto Valencia de Don Juan, la confirmación de que se trataba de la misma pieza.

21 Anteriormente se databa entre el 600 y el 550 a. C., en época de Hallstatt (Blázquez 1960: 378).

22 D. José Manuel Pastor nos ha informado que han realizado de forma experimental, él y su equipo «Arqueodromo», un casco de bronce sobre capacete de esparto trenzado de $1 \mathrm{~cm}$ grosor que amortiguaría golpes y permitiría respirar al cabello. El casco fue utilizado durante la «Saturnalia» celebrada el 23 de agosto de 2002 en Segeda, Mara, Zaragoza, con resultado y efectividad altamente satisfactorio. 
570); pero creemos que el hecho de que al menos uno de ellos tenga huellas de una reparación desmiente esa idea. También debemos recordar por los grosores anteriormente citados, que la lámina de bronce de estos cascos celtibéricos, es mucho más fina y ligera que la de los cascos corintios que si podían resistir golpes fuertes de una espada o una lanza y precisaban un forro acolchado para mayor protección y comodidad (Quesada 1997: 550; 2003: 102).

La decoración del casco de la sepultura «A» mediante los círculos y semicircunferencias radiadas tantas veces repetidos sobre pectorales, fíbulas o broches de cinturón de la época, se interpreta dentro de la Edad del Hierro de la Meseta, y en general dentro del mudo céltico, ligada a cultos solares, a la vez que las dobles líneas de espigas se relacionan con el agua, con la línea de separación entre el mundo de los vivos y los espíritus. Los círculos y las semicircunferencias serían, en definitiva, representaciones astrales que significan el discurrir de la vida, trasunto de la muerte y la resurrección del sol o la luna, la relación del ciclo de la vida y su continuación en el más allá; por todo ello se usarían como símbolos apotropaicos, es decir de protección al portador (Dechelette 1910: 413-444; Cabré y Morán 1975: 608). Son interpretaciones que pueden ser discutibles, pero su reiteración, las distintas combinaciones dentro del mundo celtibérico, en cascos, pectorales y otras piezas, sugieren que al menos en momentos antiguos, eran algo mas que una mera decoración y que luego pudieron estandarizarse y vulgarizarse, valorándose mas el objeto en sí mismo que su decoración (Cabré y Morán 1975: 607; Barril 1996: 196).

No obstante, también nos planteamos que sean una transposición de los discos aplicados o faleras que decoraban y reforzaban algunos cascos semiesféricos o cónicos hallstátticos, realizados en materia orgánica, cubiertos de gruesos remaches y con botón terminal y, considerando que ambas interpretaciones no tiene porque ser excluyentes. Los cascos a que nos referimos proceden en su mayoría de la zona noreste de la actual Italia y de Eslovenia, como los de Verocchio o St. Gabrovec, respectivamente (Feugère 1994: 23; Egg 1988: 214- 216).

\section{CASCO DE LAS EXCAVACIONES DE TARACENA}

D. Blas de Taracena que fue director del Museo Celtibérico de Soria primero, y del Museo Arqueológico Nacional después, fue uno de los más afamados estudiosos y defensores de la cultura celtibérica a la que intentó caracterizar, para lo que se valió de los resultados obtenidos en sus excavaciones desde los años veinte. Una de las excavaciones en las que trabajó y que recogió en la Carta Arqueológica de Soria (Taracena 1942: 32-34), pero, lamentablemente, no llegó a publicar, es la de la necrópolis de Cerro Monóbar, en Almaluez, Soria ${ }^{23}$.

\section{CAsco de Almaluez, Soria}

Fue mencionado por Taracena (1942: 33) y Cabré (1942: 198) como una de las piezas relevantes de Almaluez y, Domingo lo describe muy brevemente en la Memoria de Licenciatu$\mathrm{ra}^{24}$ que realizó sobre los materiales de la necrópolis de Almaluez, descripción que hace referencia a motivos geométricos repujados sin dibujarlos (Domingo 1980: 23), y completa la

23 El malogrado D. José Luis Argente, que fue director del Museo Numantino obtuvo unas copias de los diarios de Taracena que, según el mismo explicaba, tenía el profesor Pedro de Palol (Argente 1994: 168). Hemos podido consultar una copia que aquel cedió a Dña. Concha Ballano, pero en la que no hay mención directa al casco. Hemos consultado con los profesores D. Alfredo Jimeno y D. Alberto Lorrio si recordaban algún dato al respecto, dado que ellos también habían tenido acceso a la copia, pero la respuesta ha sido negativa.

24 Agradecemos a Dña. Lydia Domingo la amabilidad de permitirnos consultar su trabajo. 
información con una fotografía que muestra su gran fragmentación en el resumen publicado de aquella (Domingo 1982: lám. IV.1). El resto de los autores que lo mencionan lo hacen a partir de las primeras descripciones de 1942, que lo relacionan con los cascos de Alpanseque y de la fotografía publicada en 1982, adscribiéndolo Schüle (1969: 116-117) a su fase 'A antigua de la Cultura del Tajo', Quesada (1997: 552, nº 4036) al siglo V a. C. y Lorrio (1997: fig. A y C) a su 'Subfase A.1 del Alto Tajo Alto Jalón'.

Aunque las referencias hablan de un único casco, creemos que podemos señalar la presencia de al menos dos cascos en esta necrópolis; ambos en un estado muy fragmentado e incompleto que somos incapaces de recomponer.

\section{Contexto}

El ejemplar al que denominaremos casco 1 de la necrópolis de Almaluez es el fotografiado por Dña. Lydia Domingo, se halló durante las excavaciones llevadas a cabo por D. Blas Taracena entre 1933 y 1934, y actualmente está adscrito al ajuar de la sepultura 155, pero la documentación con que contamos no nos permite garantizar que realmente sea ese su contexto.

Lydia Domingo halló los fragmentos de casco junto a los materiales de la sepultura 46, sepultura que se excavó en 1933 y cuyo contenido según los diarios, era «Restos inútiles de una armilla y de unos trozos de urna roja a torno y de un pequeño collar de diminutas gargantillas de bronce» (Taracena 1933: 19 b; Barril 1997: 29). Esta descripción no coincide con el conjunto de materiales que la citada autora localizó etiquetados con el número 46 de sepultura, y que se conservan actualmente - a excepción, precisamente, del casco- - y que son el puente y el pie de una fíbula de pie vuelto, un broche de cinturón de 3 garfios y escotaduras laterales incompleta y un fragmento de cerámica.

Junto a los materiales de esta sepultura $\mathrm{n}^{\circ} 46$ se conservan dos hojas de papel 'Guarro', tamaño DIN-A3, con un dibujo esbozado titulado 'Casco de Almanuez' (sic) en el reverso, con letra de la época ${ }^{25}$ (Fig. 26). El dibujo muestra unas láminas de una media de siete centímetros de longitud y con una decoración que se asemeja mas a las descripciones de Taracena y Cabré, al compararlo con el casco de la sepultura de Alpanseque, que a los restos de las láminas catalagodas como tal, por lo que nos planteamos que el casco del que hablaban esos autores y el que fotografió Domingo eran piezas distintas y era preciso revisar todos los restos de láminas de la necrópolis, y la conveniencia de poder consultar detalladamente todos los diarios de Taracena para poder llegar a una conclusión válida, extremo este último que ignoramos si será posible.

Como se ha señalado el casco está actualmente inventariado como hallado en la sepultura 155, suponemos que excavada en 1934, y cuyo contenido no figura relacionado en la copia de los diarios a los que hemos tenido acceso. Los materiales que actualmente se conservan en la tumba 155, coinciden con los que describió L. Domingo, a excepción del casco.

La sepultura 155, contiene objetos de indumentaria y adornos, como la anterior, y además armas: en hierro, un soliferrum incompleto, dos puntas de lanza, dos regatones, varios pequeños fragmentos de enmangues tubulares, una pieza de uso indeterminado, igual a una de la tumba 30 de Padilla de Duero, y que consiste en un vástago rematado en cabeza esférica en un lado y en una doble placa remachada en el otro (Sanz 1998; señ 30 AE), el resorte y la aguja de una fíbula tipo 7C de Argente (1994: 174n no 25) y varios fragmentos de lámina. En bronce, media fíbula tipo 7D de Argente, decorado con círculos troquelados en el disco

25 La letra no sabemos exactamente a quien pertenece, dado que su comparación caligráfica con escritos de Taracena y de Juan Cabré nos indica que no corresponde a ninguno de los dos. El término «Almanuez» (y no Almaluez), se encuentra además escrito tras haber tachado Alpanseque como se puede observar en la figura 26. 
en que remata el pie vuelto y línea de espigas en el puente (Argente 1994: 174, nº 28), una placa de cinturón pasiva con dos filas de seis huecos y decoración de granetti, una estrecha lámina con decoración en zig-zag repujada, cuatro cuentas de collar de bronce de distinto tamaño y dos colgantes en ocho.

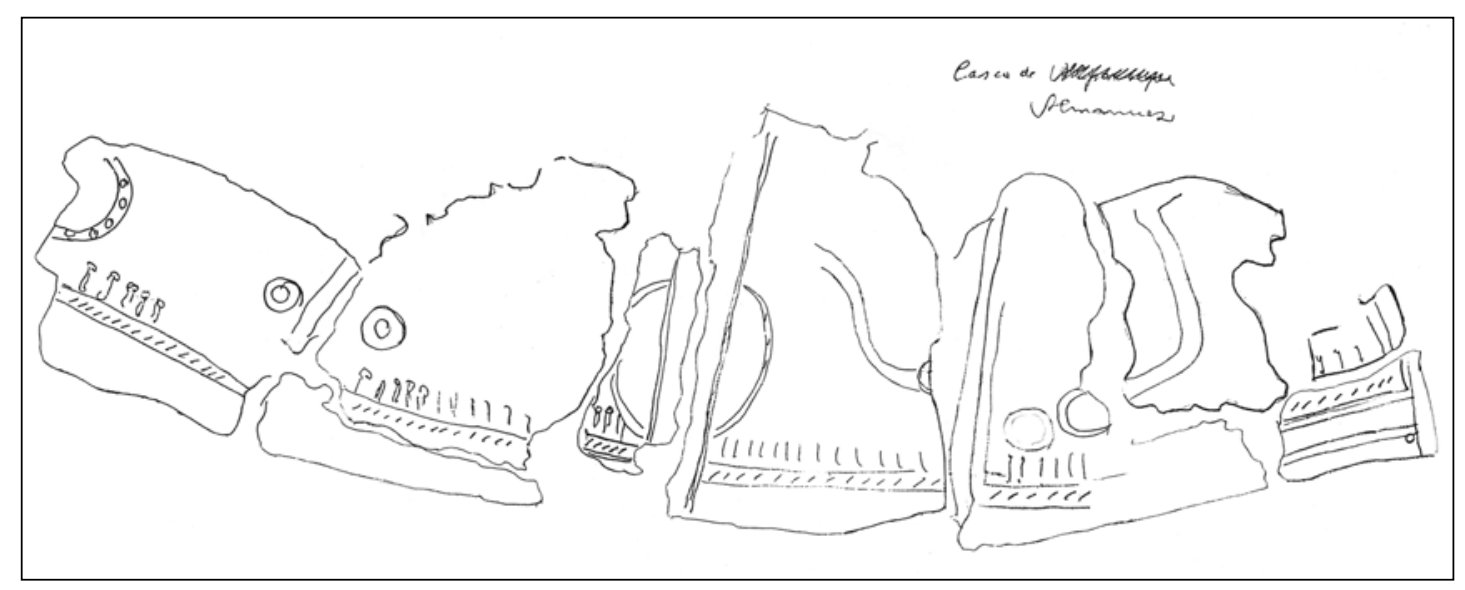

Fig. 26. Casco de Almaluez, según dibujo de ¿Taracena?

El número y mezcla de elementos de adornos, indumentaria y armas, de esta sepultura indican un ajuar de gran riqueza, cuyo contenido podría ser coherente con la presencia de un casco en ella, pero que como hemos explicado, no podemos dar por válida. En cualquier caso los colgante en ocho y la placa de cinturón proporcionan una cronología antigua dentro de las necrópolis celtibéricas, lo que corrobora el hecho de que las armas sean todas de astil, ya que según la periodización de Lorrio podrían encuadrarse a finales de su fase I.

Los fragmentos que vamos a describir de este «casco 1» se han hallado con dos pequeñas etiquetas, en una está escrito en el anverso, «Almaluez 155», con letra de Taracena, y en el reverso «c 46», también a lápiz y con similar grafía, en la otra etiqueta esta escrito, a tinta y con otra letra, «todo es una». En el conjunto de los materiales de la necrópolis se ha interpretado que las etiquetas con un número, precedido del nombre de la localidad eran las sepulturas; pero en ocasiones, sólo está el número y, la letra «c», desconocemos a que hace referencia; por ello parece justificada la duda sobre la sepultura de procedencia y, aunque ignoramos todas las claves ${ }^{26}$, su asignación a la 155 es dudosamente razonable.

El que denominamos casco 2, se recompondría a partir de un grupo de láminas de bronce muy fragmentadas y mineralizadas, inventariadas entre los materiales de la necrópolis sin adscripción a tumba concreta. Los fragmentos en los que se puede interpretar algún motivo repujado, son mucho más cercanos a los reflejados en el dibujado localizado los materiales de la tumba 46 que los del 'casco 1' y, aunque faltarían muchos de los fragmentos dibujados para completarlo, creemos que podríamos estar ante los restos de la pieza dibujada, por Taracena o alguien cercano a él.

26 Pocos años después de haber realizado y publicado Dña. Lydia Domingo su Memoria de Licenciatura, un equipo de trabajo en el Museo Arqueológico Nacional, revisó estos materiales y los reinventarió de acuerdo a nuevas instrucciones. Suponemos que el cambio se produjo en este momento e ignoramos si tuvieron acceso a información complementaria. Nos vemos, por tanto, obligados a plantear su pertenencia a la sepultura 155 sólo como una hipótesis y descartamos la posibilidad de la sepultura 46 en base a los diarios de Taracena, a los que Domingo no tuvo acceso. 


\section{CASCO 1 de Almaluez}

\section{Descripción (Fig. 27 y 28)}

El que denominamos 'casco 1 de Almaluez' se encuentra absolutamente incompleto y troceado en pequeñas láminas de bronce decoradas y lisas, con las que no es posible determinar su forma y decoración exacta: Se conservan actualmente inventariados, con varios números independientes y correlativos, 1952/10/155/27 a 7027, debido, precisamente, a que aunque se suponía que pertenecían a la misma pieza y los análisis metalográficos lo han confirmado, no es posible recomponerlos. Entre los fragmentos conservados del casco se encuentran muchos remaches y plaquitas con perforaciones para otros.

Destacamos los motivos decorativos de varios fragmentos. Uno de los más interesantes es el inventariado 1952/10/155/68 que está formado por dos láminas unidas verticalmente por tres remaches de bronce muy aplanados; el borde inferior de ambas láminas está bordeado por una franja de cortas líneas verticales, alternando repujados y acanalados. Su límite superior es una línea acanalada horizontal, paralela al borde y sobre ésta. Pero sobre está línea, mientras en la lámina de la izquierda no hay nada, en la derecha se suceden, en serie tres grupos de dos triángulos abiertos, uno dentro del otro y rematados en el vértice por un botón.

Otro fragmento, el $n^{\circ}$ 1952/10/155/48 que hemos podido unir con el 1952/10/155/45, muestra esta misma serie de triángulos inscritos y repujados con el vértice en botón, sobre ellos un espacio sin decoración metopado entre un grupo de tres líneas paralelas verticales acanaladas a la izquierda y otra a la derecha, que posiblemente pertenecería a un grupo similar. Sobre este espacio liso metopado una fila de botones, en cazoleta y bastones acanalados, y sobre ellos otra fila de botones que posiblemente sean la cabeza de otros bastones - con efecto repujado en el reverso 28 .

En otro conjunto de fragmentos, como $\operatorname{los} \mathrm{n}^{\circ}$ 1952/10/155/40, 43 o 49, sobre un nervio horizontal se sitúa una fila de bastones repujados inclinados de forma paralela, con puntos igualmente repujados, y sobre ella otra serie de bastones. Otros fragmentos muestran líneas de espiga vertical o series de V inscritas; entre ellos destacamos el 1952/10/155/46 que sobre la base de un nervio horizontal presenta dos nervios verticales paralelos que enmarcan la espiga; también sobre un nervio horizontal, en la mitad derecha de este fragmento, y dentro de la banda citada, se sitúa una serie de bastones verticales repujados terminados en botón; mientras que en el lado izquierdo se aprecian los catetos de un triángulo abierto. Llamamos la atención sobre un pequeño fragmento que tiene varias anillas abiertas colocadas en el borde de la lámina, a modo de adorno, sin relación aparente con el resto de fragmentos del casco.

Entre los fragmentos hay varios con perforaciones de 3 o $4 \mathrm{~mm}$ de diámetro para remaches, y destacamos el inventariado como 1952/10/155/29, que indica que la pieza sufrió una reparación, ya que la lámina de bronce está rota y se ha reforzado colocando otra lámina de bronce detrás de su zona izquierda, mientras que en la derecha se han colocado dos chapitas, una de bronce, en el anverso y otra de hierro, en el reverso, remachadas conjuntamente.

Hay otros muchos fragmentos informes y de tamaños en torno a un centímetro y sin decoración, que lamentablemente no es posible organizar para reconstruir el casco y por ello, en este trabajo, nos hemos limitado a presentar únicamente una selección de aquellos que por su tamaño o decoración proporcionan mayor información.

\footnotetext{
27 Algunos de estos números comprenden varios fragmentos informes.

28 Esta disposición de la decoración alternando acanalado y repujado en los mismos fragmentos nos ha planteado dudas de descripción y dibujo, al no estar seguros de a qué debíamos considerar anverso y a qué reverso
} 


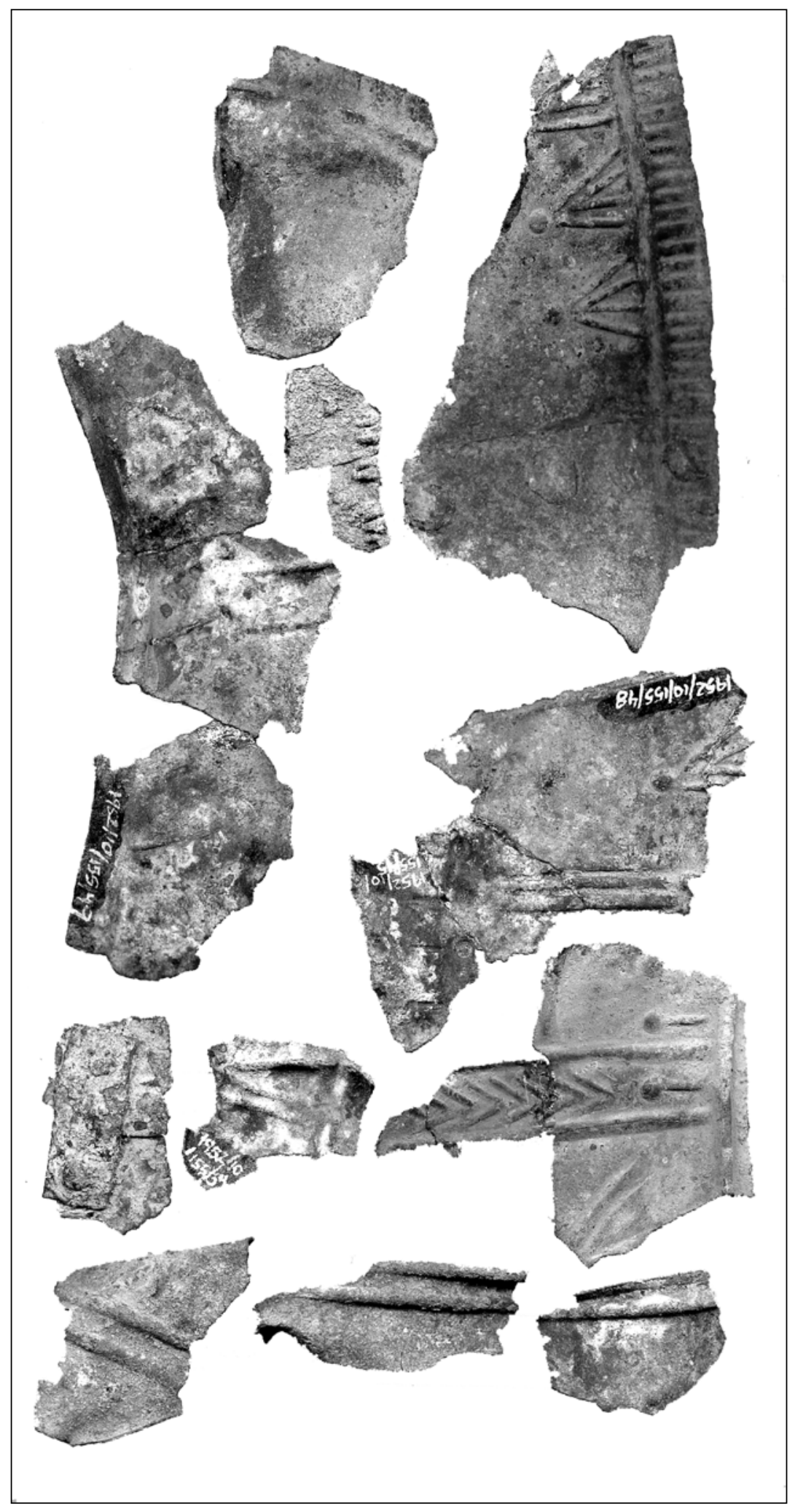

Fig. 27. Casco 1 de Almaluez: selección de fragmentos, estado actual. 


\section{Análisis técnico}

Como los anteriores cascos, se trata de una pieza realizada en un bronce binario en una lámina muy adelgazada.

Estructuralmente estaría compuesto por láminas unidas entre sí mediante remaches de bronce muy machacados y aplanados y llevaría decoración dispuesta en series mediante repujado y acanalado. Es interesante destacar que en la reparación que, sin duda, se realizó, se utilizaron pequeñas láminas rectangulares de hierro y bronce.

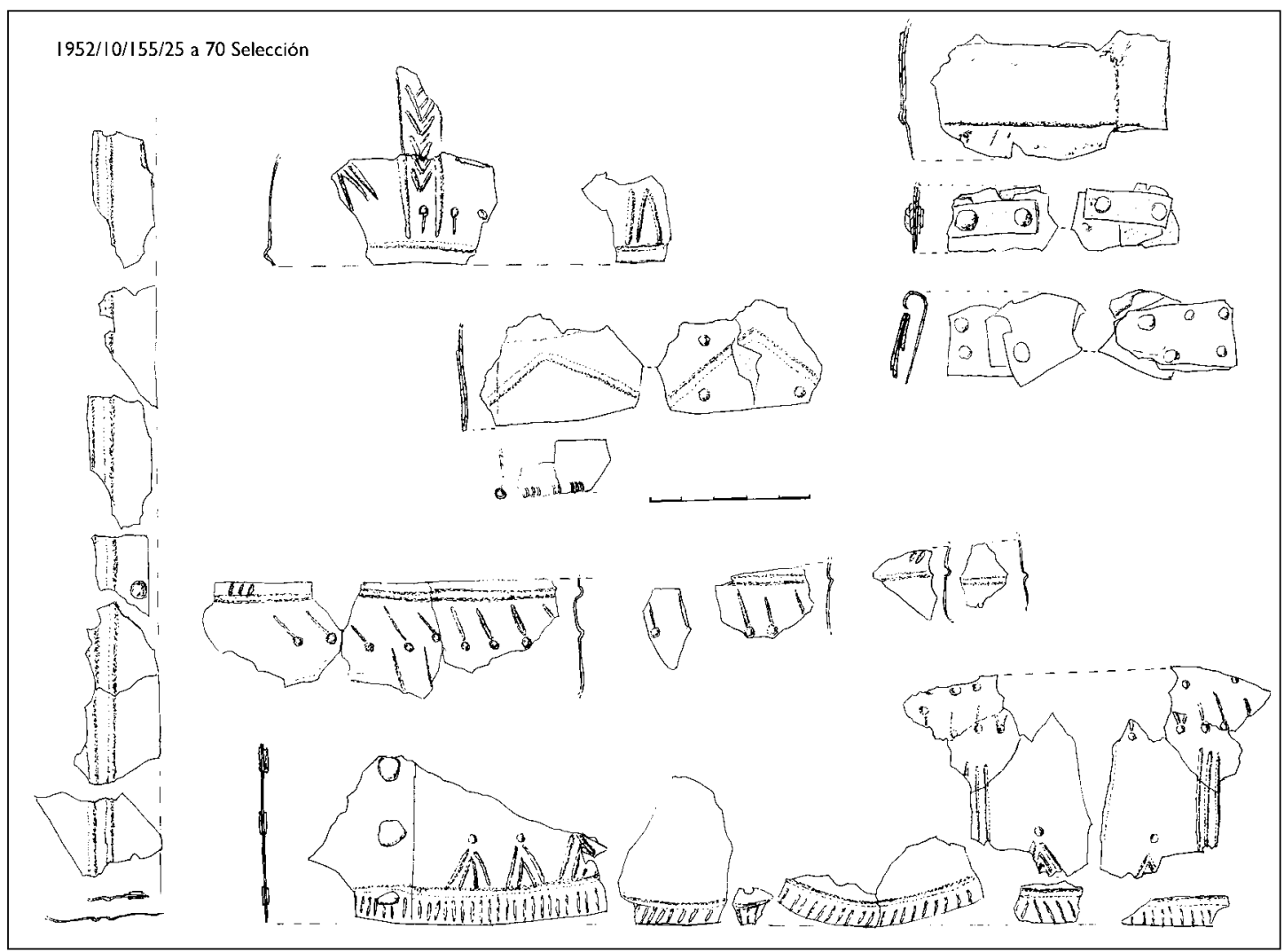

Fig. 28. Casco 1 de Almaluez: selección de fragmentos, estado actual. Dibujo M. Barril.

\section{CASCO N$^{\circ} 2$ DE ALMALUEZ}

Descripción (fig. 29 y 30)

Los fragmentos del que denominamos 'casco 2 de Almaluez' se encuentran agrupados entre los números de inventario $1952 / 10 / 693$ a $696^{29}$. Son fragmentos de lámina de bronce de $2 \mathrm{~mm}$., aunque este grosor está sobredimensionado a causa de las fuertes alteraciones del metal. Algún pequeño fragmento conserva restos de una lámina muy perdida de hierro y el número 1952/10/ 695 comprende varios pequeños fragmentos de hierro informes.

\footnotetext{
29 Cada número comprende una media de veinte fragmentos de pequeño tamaño.
} 
Al menos cinco de los fragmentos nos muestran dos nervios repujados, con una banda entre ellos que forman escuadra; de ellos dos forman escuadras dobles, es decir a derecha e izquierda, dejando en las zonas de demarcación hasta cuatro nervios. Las bandas que quedan entre los nervios, en algún caso parecen estar parcialmente rellenas con cortas líneas diagonales, pero su estado es tan pésimo que es difícil determinar su distribución. Otros fragmentos que irían en el interior de los compartimentos creados por las líneas nervadas, nos muestran, unos, series de triángulos repujados, posiblemente estampilla, con botones repujados en su vértice y, otros, círculos concéntricos con también repujados con umbo central destacado. Sobre parte de la serie de triángulos con botones se documenta otra fila incompleta que estaría compuesta por bastones igualmente repujados.

Lamentablemente y como ya se ha indicado, el estado en que se encuentran no permite aventurar mucho mas, e incluso puede que se trate de un gran pectoral y no de un casco, pero, como ya hemos señalado, el conjunto de estas decoraciones descritas se aproximan mucho mas a las del dibujo hallado junto a los materiales de la sepultura 46 de la necrópolis y titulado «casco de Almanuez» que los de la pieza fotografiada en 1982.

\section{Análisis técnico}

Al igual que los anteriores ha sido analizado por D. Salvador Rovira, a pesar del estado de mineralización del bronce, con resultados similares a los de los demás cascos.

Entre los fragmentos no tenemos documentado ningún remache, ni ninguna lámina solapada sobre otra y la distribución de los nervios, formando escuadra y compartimentando el espacio en al menos dos zonas, nos inclina a pensar que estamos ante una pieza realizada de manera unitaria.

\section{Adscripción tipológica de los cascos de Almaluez}

Taracena mencionó la existencia de un casco de bronce con soles radiados como los de Alpanseque en la Carta Arqueológica de Soria (1941: 32), dato que como hemos visto reitera Cabré al destacar su pertenencia a una industria floreciente de bronces repujados (Cabré 1942: 193-196) y, es una descripción que se corresponde con el dibujo conservado entre los materiales (Fig. 26). De nuevo Schüle recoge la nota (1969: 117) y por fin en 1982 Lydia Domingo nos ofrece una fotografía de los restos que presentamos como 'casco 1' (Domingo 1982; lám. IV, 1), pero sin dedicarle mención especial. Como acabamos de explicar, creemos que en Almaluez, podemos documentar restos de un 'casco 2', pero el estado de ambos no nos permite avanzar mucho en su conocimiento

El casco mencionado en la bibliografía se considera que pertenecería al grupo de los cascos de Alpanseque, cascos cónicos o en ojiva decorados con temas que se interpretan como apotropaicos y que podían llevar penachos en dirección transversal o vertical. Y en efecto, parece que el 'casco 1' podría estar realizado en varias láminas remachadas entre sí, como el casco de la 'sepultura A' de Alpanseque, aunque sin que sea posible determinar su tamaño. En cambio, el 'casco 2' estaría realizado en una sola pieza, al igual que el casco de la 'sepultura 20?' de Alpanseque'.

La decoración repujada y los motivos que presentan ambas piezas de Almaluez, nos pone de nuevo en contacto con la que es frecuente en ámbitos de la Península itálica durante los primeros tiempos de la $2^{\mathrm{a}}$ Edad del Hierro y en ámbitos cercanos de ambiente hallastáttico (Dechelette 1910: fig. 174). Se trata aquí de motivos repetidos, dispuestos en filas paralelas, que se alternan con otros motivos en la fila siguiente o vuelven a repetirse. 


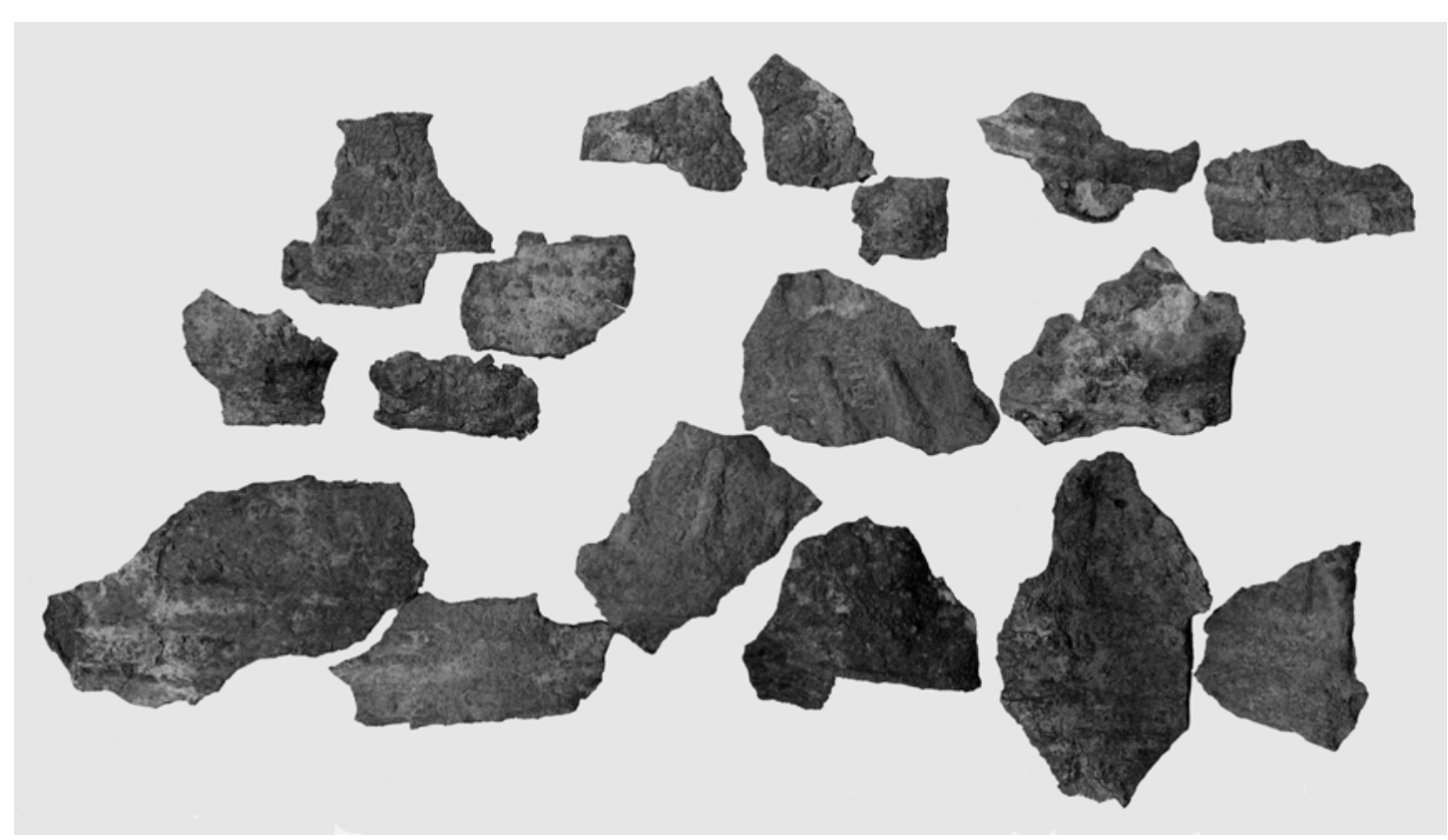

Fig. 29. Casco 2 de Almaluez: selección de fragmentos, estado actual.

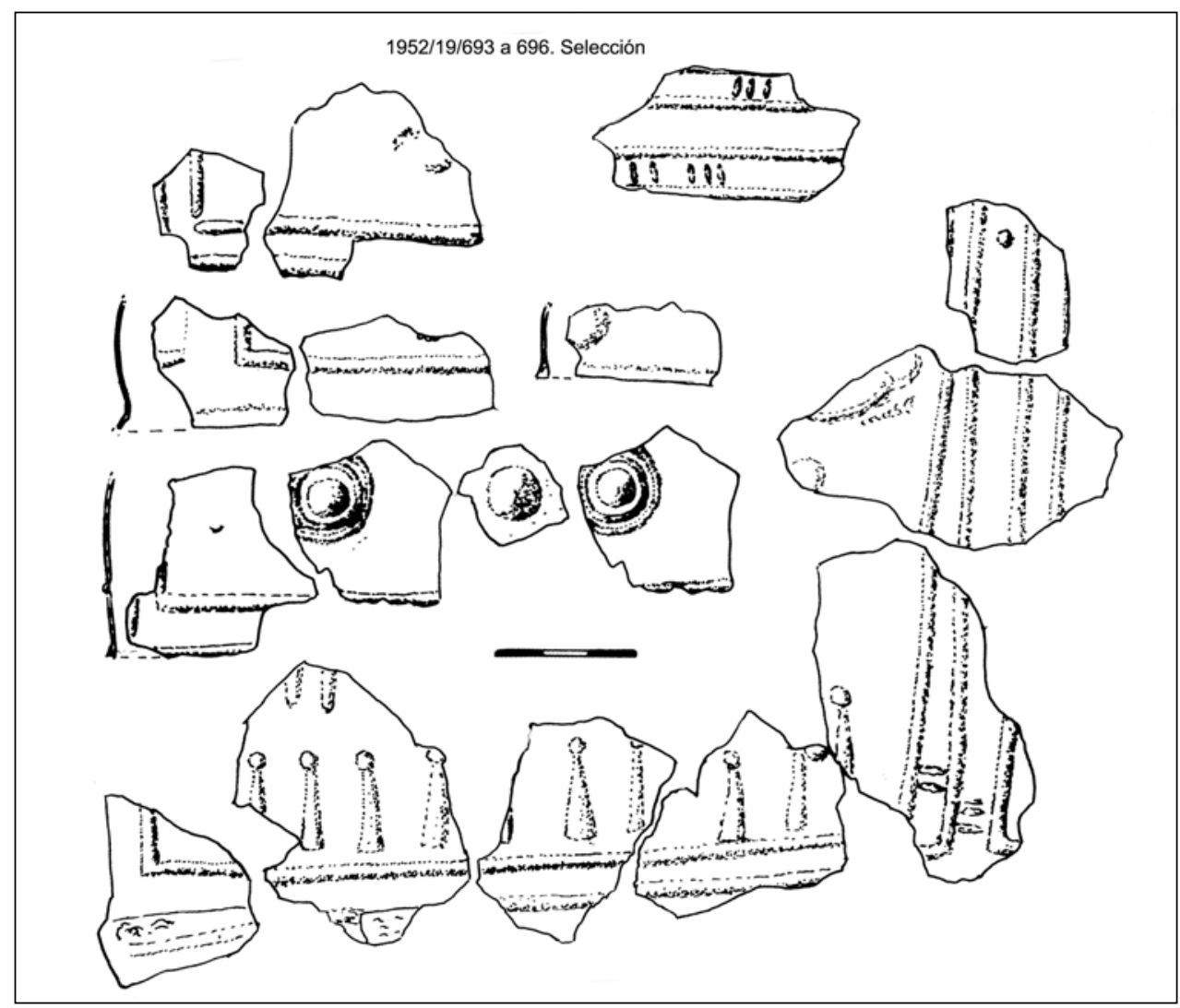

Fig. 30. Casco 2 de Almaluez: selección de fragmentos, estado actual. Dibujo M. Barril. 
Nos sorprende en el 'casco 1' la alternancia de motivos repujados y acanalados, es decir trabajados unos por el derecho y otros por el revés, sin que podamos decidir si se trata de algo deliberado para conseguir una especie de juego cromático, luces y sombras o si se hizo así por un tema práctico a la hora de trabajar.

En cuanto a la iconografía, no parece que puedan interpretarse como 'soles radiados' ninguno de los motivos, a pesar de la descripción que de ellos se hacía en la bibliografía, ya que en el 'casco 1' no vemos círculos y los del 'caco 2' son concéntricos, con umbo y, aunque son muy similares a los de muchos pectorales tanto de placa rectangular como los discoidales de Aguilar de Anguita (Cabré 1942: fig. 10), carecen de radios.

El resto de los motivos, los triángulos inscritos uno dentro de otro o rellenos y rematados en botones en los vértices y los bastones también rematados en botones, son temas que encontramos reiteradamente en la cerámica con decoración plástica, especialmente en la de la zona vettona, más que en la propiamente celtibérica, pero que no obstante nos pone en relación con una tradición local formal y temática. Si corresponden a estilizaciones de formas reconocibles, como posibles personajes, en los que los botones representarían la cabeza o, son simples motivos estandarizados, carecemos de datos para definirnos.

\section{OTROS CASCOS CELTIBÉRICOS}

El número de cascos completos conocidos dentro del mundo celtibérico es muy escaso, y siguen modelos algo distintos a los que estudiamos. Los dos que podemos citar presentan ambos el inconveniente de carecer de procedencia segura, y haberse adquirido ambos en el mercado de antigüedades.

1. El primero de ellos estaba en la colección Pérez Aguilar en 1990 (fig. 31), los autores de su estudio lo relacionan con la forma de los de Alpanseque, pero lo consideran cronológicamente posterior, del III a.C., ligado a cascos griegos e itálicos y con posible procedencia en los alrededores de Numancia (Álvarez, Cebolla y Blanco 1990: 296, 303, fig. 30); otros autores, como Lorrio o Quesada no se atreven a clasificarlo y lo denominan 'indeterminado'. Se trata de un casco de forma ovalada y picuda, con estrecho cubrenuca solidario con el capacete, que mide $13 \mathrm{~cm}$. de alto por 21 de longitud y $16,5 \mathrm{~cm}$. de ancho; a ambos costados presenta dos perforaciones que permitirían sujetar unas yugulares o paragnátides. Presenta una reparación antigua en el guardanucas. La decoración está formada por líneas acanaladas, dejando un nervio en resalte, que lo contornea, marcando la zona de las orejas, y creando amplios arcos sobre la frente, motivo que recuerda vagamente a la decoración que llevan cascos tan distantes cronológicamente como los cascos calcidios, algunos apulo-corintios, del siglo VI a. C. y los cascos romanos de tipo Weisenau. En efecto, la decoración y el hecho de que esté preparado para llevar paragnatides podría hacernos pensar en un casco inspirado en los calcidios evolucionados, algunos de los cuales se fabricaron en Apulia y Tarento (Feugère 1994: 22), lo descartamos ya que en éste las orejas no están recortadas. La forma de la calota y el hecho de llevar un pequeño guardanucas recuerda algo mas al denominado tipo greco-itálico o etrusco, pero del que se diferencia por la ausencia de carena y por no tener recortada la oreja, ni un pequeño botón rematándolo; aunque ésta es una característica no tienen todos (Feugère 1994: 35, Izquierdo y Solías 1992: 606). Pero, otros aspectos de este ejemplar de la colección Pérez Aguilar, lo acercan mucho mas a los cascos de tipo céltico antiguos, que Jacobsthal integraba en su grupo A y pensaba estaban realizados en el norte de Francia, tal vez imitando a cascos itálicos, como el de la colección Chance, de Reims ${ }^{30}$, que consideraba el más antiguo del tipo (Jacobsthal 1944: 115, 179 y lám 177, no 139); el tamaño,

\footnotetext{
30 La colección es de 1930, y procedía de una tumba de carro de la necrópolis de Marquisis, cerca de Prunay, Francia.
} 
la forma del casquete (más semiesférico y achatado el francés) y del pequeño guardanucas, es muy similar, e incluso conserva remaches de las paragnatides, pero se diferencia en la presencia en el casco francés de un doble botón ovoide como remate y en la decoración. El casco podría ser estar, por tanto, inspirado en la observación de alguno de estos tipos de cascos y su libre interpretación, pero no parece tener relación con los de Alpanseque.

El hecho de que falten las yugulares es lo habitual en los cascos hallados en la Península Ibérica en época prerromana y que siguen modelos que en Europa si las conservan. Esta reiteración en la ausencia y el hecho de que no se vean reflejadas en la iconografía, ya hemos indicado que ha llevado a comentar a algunos autores que podría ser debido a que para su forma de lucha eran un impedimento.

2. El segundo casco al que nos referíamos pertenece a la colección de Torkom Demirjian, de Nueva York, cuya colección fue expuesta en 1992 y 1993 con motivo del $5^{\circ}$ centenario de Descubrimiento de América, primero en el Museo de la Universidad metodista de Dallas, conocido como Meadows Museum, y después en la Ariadne Gallery de Nueva York ${ }^{31}$ (Fig. 32).

Se trata de un casco que Burillo (1992: 76-77, $\mathrm{n}^{\circ} 74$ ) describe «Casco celtibérico del siglo $4^{\circ}$ a. C., en bronce, de 8 "' de diámetro y 6,5" de altura (es decir 20,32 cm. y 16,5 cm. respectivamente). Realizado sobre una lámina de metal martilleada y decorada con motivos repujados. Bandas simples se entrecruzan y rodean el casco dividiéndolo en cuadrantes. Se ha cortado una apertura cuadrada en el frente para la cara. Cada cuadrante contiene un motivo de tres figuras esquemáticas bajo un 'disco solar' con un anillo de puntos. Las figuras humanas con los brazos elevados y una de sus piernas levantada del suelo parecen estar inmersos en una danza extática. Los escritores romanos que observaban las costumbres belicosas de los celtíberos describían danzas de este tipo. Dos proyecciones en la banda transversal del casco indican que sujetaban un ornamento o penacho» ${ }^{32}$.

Esta descripción de Burillo se acompaña de dos fotos de gran calidad, una de las cuales incluimos aquí por deseo expreso del autor.

El casco tiene forma semiesférica, está hecho en una sola pieza y, posiblemente en un principio tenía forma cerrada, para ser utilizado como casquete, como la que tendrían los cascos anteriormente mencionados de Alpanseque y, en un segundo momento de uso, se recortaron dos medios cuadrantes contiguos para permitir acercarlo al cráneo y proteger los laterales de la cara, aunque es posible que no llegase a la nuca. Creemos que ha sido recortado en una segunda fase debido a que los bordes se perciben afilados, como cortados con cuchilla y, sin rematar. Por este motivo hay dos 'círculos solares' en cada cuadrante y dos grupos de tres figuras en cada uno de ellos; pero, en los dos cuadrantes correspondientes a la parte frontal no hay figuras bajo el círculo. El resultante es un casco cuya morfología está directamente relacionada con la de los capacetes que reflejan los exvotos ibéricos citados anteriormente o la escultura del guerrero de Porcuna.

Hay que destacar otros aspectos del casco que observamos a través de las fotografías como son a) que tiene restos de una cinta de hierro en la banda central que cruza la cabeza de nuca a frente; b) tiene perforaciones situadas alrededor de la cara que posiblemente sujetaban una banda decorativa: tres en cada uno de los lados, en la base, en el centro y junto al ángulo con el corte horizontal de la frente y dos en ella, a ambos lados de la banda central; c) varias perforaciones rodean espaciadamente la base del casco e indican que una banda decorativa recorría el contorno inferior del casco, y otras tres perforaciones forman un triángulo en la base de las bandas transversales, d) En la misma banda vertical donde se ubican las tres per-

31 Nos pusimos en contacto con el conservador del Meadows Museum, Dr. Mark Roglan, a fin de solicitar datos sobre su actual paradero y, amablemente nos remitió al Sr. Torkom Demirjian, Director de la Ariadne Gallerie, de Nueva York, el cual ha tenido la gentileza de informarnos que sigue manteniendo la colección e incluso la ha incrementado.

32 El texto original está en inglés. Creemos interesante mencionar que este casco ha sido reproducido como recortable por el Equipo Arqueodromo, de Zaragoza, equipo que también ha realizado una réplica del mismo en cuero. 


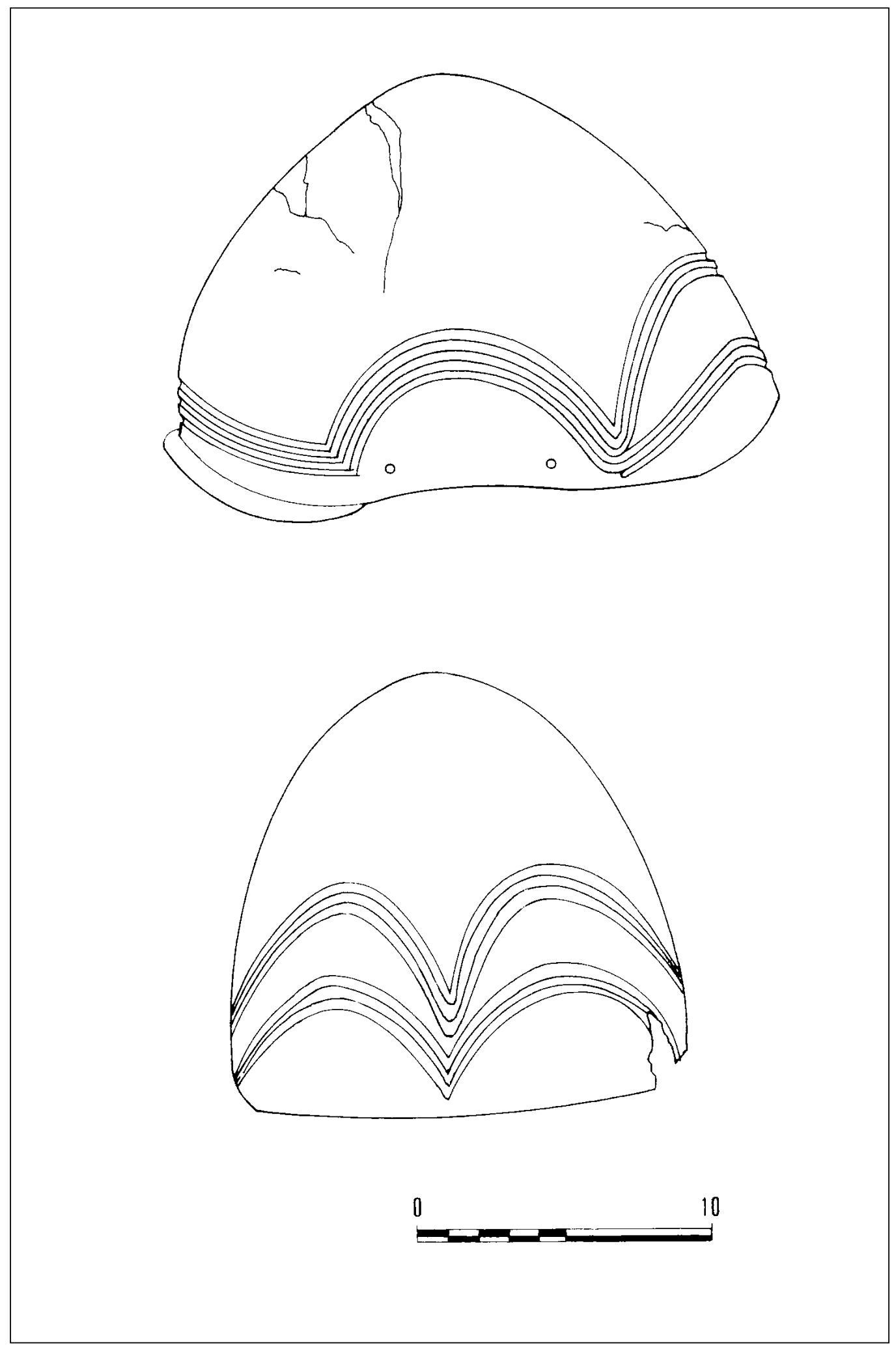

Fig. 31. Casco de la colección Pérez Aguilar (Álvarez, Cebolla y Blanco 1990, fig. 29). 
foraciones en triángulo de la base, se sitúan las que Burillo denomina 'proyecciones' que consisten en láminas recortadas y remachadas al casco; según una de las fotos (Burillo 1992: 77) en el lado izquierdo la lámina está recortada en forma rectangular, remachada con dos tachones y se adapta a la banda transversal a la vez que se sitúa sobre otra lámina también remachada con tres tachones, que a su izquierda, adopta forma de arco de círculo siguiendo la forma del 'círculo solar', mientras que en lado derecho (Burillo 192: 76) la lámina parece más ancha y remachada también sobre otras láminas; e) Hay una chapa remachada bajo el danzarín central situado a la derecha de la cara, lámina que tal vez fuese para reparar algún desperfecto ${ }^{33}$, lo que pondría de manifiesto la alta estima que se tenía a estas armas defensivas.

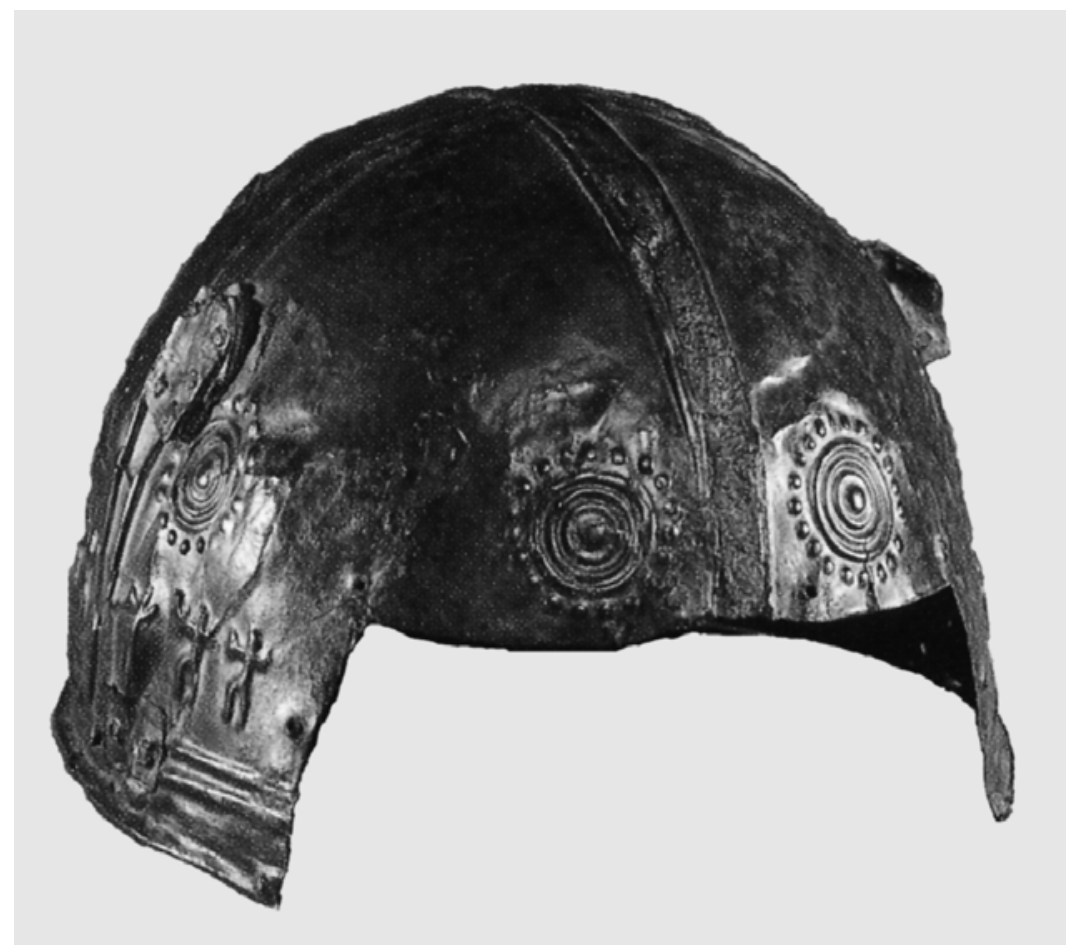

Fig. 32. Casco de la colección Torkom Demirjian (Burillo 1992: 77).

Las tres mencionadas perforaciones en triángulo, situadas en la banda inferior, en el punto de arranque de la transversal, quedarían situadas aproximadamente a la altura de las orejas y podrían servir para sujetar unas cintas o cordones para atar el casco bajo la barbilla, bien directamente, bien con una pieza de cuero, y que ya tendría antes de ser recortado para darle su nueva forma. Es esta una explicación basada en la representación de los cascos de un vaina de la tumba 994 de la necrópolis de Hallstatt, ya citada anteriormente al referirnos a los cascos de Alpanseque.

Las dos láminas de bronce que se proyectan a media altura del casco, una a cada lado podrían servir para sujetar, bien una cimera de lado a lado, bien sendos penachos que podrían completarse con uno central.

33 Evidentemente, al no conocer directamente el original, no podemos sino especular. El propio Burillo, según nos ha informado, sólo dispuso de documentación fotográfica para realizar el encargo de estudio recibido. 
Los motivos decorativos de este casco son interesantes y están en relación con los del Museo Arqueológico Nacional. Las circunferencias concéntricas rodeadas de puntos está en relación con el tema de los círculos concéntricos que ya hemos comentado anteriormente en relación a los temas solares. El motivo de los danzarines en posición frontal están emparentados con el tema grabado en la lámina de cinturón o pectoral de Alpanseque que publicaron Cabré y Morán (1975: 608, fig. 1.1) y que muestra a varias figuras estilizadas, grabadas, cogidas de la manos; acción que los autores interpretaban como una danza en torno auna representación solar.

No obstante, estilísticamente la seriación de figuras del casco neoyorkino y el hecho de que estén repujados recuerda, al igual que los ejemplars de Almaluez, a piezas broncíneas halladas en la península italiana, en vasos y pectorales vilanovianos en los que las figuras alternan igualmente con círculos concéntricos y merece destacarse la decoración de un casco de cresta procedente de Vulci con personajes punteados y botones repujados (Hase 1988: Abb.3.1). En este contexto hay que señalar otras interpretaciones que se han dado al motivo, como la de Dechelette que veía en esas figuras divinidades antropomorfizadas (Dechelette I, 1910, 432, fig. 174). Estilísticamente estas figuras también aparecen incisas sobre cerámicas del ámbito galo oriental y en el área del Danubio (ej. Necrópolis de Villement, en SaintAoutrille, Indre, según Dechelette 1913: fig. 219.1), donde se han considerado como un trasunto de las figuras esquemáticas de los vasos del Dipylon del periodo griego arcaico. Podría plantearse que es una visión en exceso difusionista, pero lo que si indica es el desarrollo de unas ideas básicas adaptadas de distinta manera por cada comunidad.

Al tratarse de una pieza de coleccionista no conocemos datos acerca de su procedencia, ni el estado en que se halló, ya que evidentemente ha sido restaurado pues presenta grietas y creemos identificar alguna zona reintegrada, pero evidentemente es de gran calidad e interés.

\section{CONCLUSIÓN}

Como conclusión podemos señalar que los cascos celtibéricos que conserva el Museo Arqueológico Nacional se hallaron en tumbas del siglo V o principios del IV a.C, que pertenecen a la fase IIA1 de Lorrio para los celtíberos y a la fase Antigua de Quesada sobre la panoplia ibérica, gracias al encuadre cronológico-cultural que se establece por el resto de los ajuares junto a los que fueron hallados, compuesto mayoritariamente por armas, algunas de ellas - como los pectorales de Aguilar de Anguita o la espada de frontón de Alpansequeemparentadas con elementos documentados de la mitad sur peninsular. Es decir, manifiestan la existencia de relaciones directas o mediante contactos intermedios con el mundo ibérico, a las que hay que añadir las relaciones con la Península Itálica, en concreto con su parte norte, más ligada al Hallstatt y a La Tène, que manifiestan los cascos objeto de estudio.

Los cascos se datan como hemos visto en un momento antiguo dentro del ámbito celtibérico, y luego en los períodos siguientes casi desaparecen, hasta que con motivo de la presencia de cartagineses y romanos en territorio peninsular se extiende otros modelos más uniformes, pero sin embargo, en las representaciones iconográficas se siguen manteniendo modelos que no se hallan en el registro arqeuológico coetáneo.

Los cascos celtibéricos podían estar realizados en una sola lámina batida o bien en varias y remachadas entre sí; se decoraban mediante motivos repujados y/o láminas superpuestas de hierro u otros apliques que servían a la vez de refuerzo y es interesante constatar que varios de ellos han sido reparados mediante la colocación de pequeñas laminitas remachadas, lo que demuestra que tenían un gran valor como objeto en si mismo. Los cascos que se conservan en el Museo Arqueológico Nacional hallados en tumbas celtibéricas tienen unas características peculiares que los hacen a todos distintos entre sí y no hemos encontrado paralelos exac- 
tos ni dentro de la Península Ibérica ni fuera, sin duda porque serían objetos exclusivos, de encargo para personajes con un prestigio claro dentro de sus comunidades.

No obstante, podemos aventurar que el de Aguilar de Anguita tiene sus antecedentes en cascos etruscos y picenos que a su vez se habrían inspirado en los griegos. Por su parte los de Alpanseque y Almaluez, muy fragmentados o deteriorados sería de tipo casquete, un modelo heredero de los del final de la Edad del Bronce con decoraciones que se han relacionado con temas apotropaicos y de protección, en los dos casos en que existen.

Los cascos celtibéricos del MAN son ejemplos evolucionados de los dos tipos básicos de cascos que Snodgrass señalaba a partir de figuritas de bronce, los cónicos y los «cap». Por otro lado debemos recordar que el color verde que nos ofrecen en la actualidad es consecuencia de la sulfuración del bronce original, que sería dorado, y por tanto, en su momento de uso, cuando se llevasen puestos sobre la cabeza serían llamativos y brillarían al sol y poseerlos sería un distintivo que muy pocos podían exhibir, como nos lo demuestra la escasez de los mismos en el registro arqueológico.

La presencia de cascos metálicos de esa época es muy escasa lo que corrobora la afirmación de Estrabón de que eran poco frecuentes entre los lusitanos puede extrapolarse al resto del territorio peninsular. 


\title{
ANÁLISIS METALÚRGICO DE CASCOS Y COMENTARIOS
}

\author{
SALVADOR ROVIRA*
}

Fragmentos o elementos de cinco cascos han sido analizados para determinar su composición química elemental utilizando la técnica no destructiva de espectroscopía por fluorescencia de rayos X. La tabla adjunta recoge los resultados de los análisis efectuados por nosotros.

Previamente, al casco de Aguilar de Anguita 1940/27/AA/287 se le habían practicado análisis en el Departamento de Ciencias de los Materiales e Ingeniería Metalúrgica de la Facultad de Ciencias Químicas de la Universidad Complutense de Madrid utilizando técnicas de metalografía por microscopía óptica y análisis cuantitativo con la microsonda del microscopio electrónico de barrido ${ }^{34}$. Los dos análisis elementales arrojaron las cifras de $84,7 \% \mathrm{Cu}$ y $15,3 \% \mathrm{Sn}$, y $85,5 \% \mathrm{Cu}$ y $14,5 \% \mathrm{Sn}$ respectivamente, perfectamente compatibles con nuestros resultados correspondientes a la chapa externa. No se detectó plomo porque la microsonda, cuando se emplea para barrer un área grande de la muestra, tiene poca sensibilidad para detectar elementos a concentraciones inferiores al 1\%. Según Ballester, el metal se obtuvo por colada y moldeo de sus componentes, sometiéndose el producto obtenido a un proceso térmico de hasta $700^{\circ} \mathrm{C}$ para después trabajarlo en frío en forma de chapa o banda, y de nuevo recocido a $500^{\circ}$ ó $600^{\circ} \mathrm{C}$. Con estos pasos se lograba la homogeneización de la aleación cobre-estaño, mejorando sus cualidades mecánicas a la hora de batir el metal para darle la forma definitiva. También apunta Ballester que el cobre habría sido obtenido por tostación de los minerales (sulfuros) y posterior reducción de los óxidos a metal, mientras que el estaño procedería de la reducción de la casiterita (Ballester 1993).

La cadena operatoria propuesta por Ballester para confeccionar los cascos laminares es, en líneas generales correcta. Sin embargo, en los objetos que han sufrido la acción del fuego durante la cremación ritual del cadáver junto con su ajuar metálico, la pira puede provocar transformaciones en la microestructura metálica por efecto térmico, como demostraron Montero y Rovira (2001). El último recocido observado en el metal podría ser consecuencia, pues, de la inutilización ritual por el fuego y no de un proceso voluntario del artesano que lo elaboró. Por otro lado, en los cascos formados por un montaje de láminas de metal unidas con roblones no parece conveniente un recocido de la pieza completa pues el calor puede producir deformaciones por diferencias de dilatación térmica que obligarían a un nuevo proceso posterior de corrección de la forma.

Este casco fue también analizado en el Instituto del Patrimonio Histórico Español con motivo de su restauración. Los resultados obtenidos ${ }^{35}, 67,66 \%$ de cobre, $27,67 \%$ de estaño y trazas de plomo (Díaz 1997), resultados que contrastan con los antes mencionados y que hacen suponer que el analista no tuvo en cuenta el efecto de la pátina de corrosión, habitualmente muy enriquecida en estaño en los bronces arqueológicos. Dada la escasa penetración de los rayos gamma usados como fuente de excitación de la muestra, se puede considerar que dicho análisis representa más bien la composición de la pátina, no del metal sano subyacente, aunque ya es indicativo de que el metal será un bronce binario cobre-estaño con algo de plomo.

\footnotetext{
* Departamento de Conservación y Restauración. Museo Arqueológico Nacional, c/ Serrano 13, 28001 Madrid; srl@man.es

34 Esta analítica fue realizada por solicitud de D. Antonio Sánchez Barriga, y D. Antonio Ballester, en 1993. De dicho informe se extraen algunos comentarios al respecto.

35 Esta analítica fue realizada a petición de Dña. Soledad Díaz y el resultado quedó integrado en el informe emitido por esta restauradora en 1997.
} 
Análisis por fluorescencia de rayos X (XRF-ED, \% en peso)

\begin{tabular}{|l|l|l|c|c|c|c|c|c|c|c|c|c|}
\hline \multicolumn{1}{|c|}{ ANÁLISIS } & \multicolumn{1}{|c|}{$\mathrm{N}^{\mathrm{a}}$ INV. } & $\begin{array}{c}\text { ZONA } \\
\text { ANALIZADA }\end{array}$ & $\mathrm{CU}$ & $\mathrm{SN}$ & $\mathrm{PB}$ & $\mathrm{FE}$ & $\mathrm{NI}$ & $\mathrm{ZN}$ & $\mathrm{AS}$ & $\mathrm{SB}$ & AG & $\begin{array}{c}\text { APAR } \\
\text { ATO }\end{array}$ \\
\hline PA5286A & $1940 / 27 / \mathrm{AA} / 287$ & Chapa externa & 84.7 & 14.2 & 0.90 & -- & -- & nd & nd & 0.071 & 0.087 & Kev \\
\hline PA5286B & $1940 / 27 / \mathrm{AA} / 287$ & Chapa interna & 84.8 & 13.7 & 0.63 & -- & -- & nd & nd & 0.074 & 0.071 & Kev \\
\hline PA5286C & $1940 / 27 / \mathrm{AA} / 287$ & Banda interior & 86.9 & 10.1 & 2.53 & 0.32 & nd & nd & nd & 0.051 & 0.057 & Kev \\
\hline MAN0016A & $1940 / 27 / \mathrm{Alp} / 46$ & Calota & 85.7 & 13.7 & 0.20 & -- & nd & nd & 0.21 & 0.061 & 0.17 & Met \\
\hline MAN0016B & $1940 / 27 / \mathrm{Alp} / 46$ & Borde inferior & 85.9 & 13.5 & 0.18 & -- & nd & nd & 0.09 & 0.054 & 0.13 & Met \\
\hline MAN0017A & $1940 / 27 / \mathrm{Alp} / 51$ & Fragmento & 89.4 & 10.3 & tr & 0.22 & nd & nd & nd & 0.014 & 0.043 & Met \\
\hline MAN0017B & $1940 / 27 / \mathrm{Alp} / 51$ & Fragmento & 89.7 & 10.1 & tr & 0.15 & nd & nd & nd & 0.016 & 0.049 & Met \\
\hline MAN0015A & $1952 / 10 / 155 / 48$ & Calota & 91.1 & 8.25 & 0.17 & 0.22 & nd & nd & nd & 0.057 & 0.063 & Met \\
\hline MAN0015B & $1952 / 10 / 155 / 48$ & Calota & 91.3 & 8.20 & 0.17 & 0.19 & nd & nd & nd & 0.17 & 0.074 & Met \\
\hline MAN0126 & $1952 / 10 / 696$ & Fragmento & 87.1 & 12.6 & nd & -- & nd & nd & 0.04 & 0.088 & 0.042 & Met \\
\hline
\end{tabular}

Abreviaturas: -- elemento no analizado, en este caso por efecto de contaminación superficial con sales de hierro; nd elemento no detectado; tr elemento detectado como trazas inferiores a $0,01 \%$.

Aparatos: Kev, espectrómetro KEVEX A7000 del IPHE; Met, espectrómetro Metorex X-MET920 del MAN.

En conjunto, las composiciones de las aleaciones de base cobre empleadas en los cascos indican la preferencia por bronces con contenidos de estaño variables pero dentro de la gama adecuada para un material que se trabaja bien por martilleo en frío en la fase constructiva de conformado. Todas están por debajo del $15 \%$ de estaño, cifra a partir de la cual se producen segregados de fase delta muy dura que no se pueden redisolver por tratamiento térmico y que hacen del bronce un material duro y frágil, más difícil, por tanto, de laminar.

\section{ADDENDUM}

Ya redactado este trabajo, el Ministerio de Educación, Cultura y Deporte ha adquirido, para asignar a la colección permanente del Museo Arqueológico Nacional, un número de armas pertenecientes a la colección de armas que, Axel Guttmann, fallecido en el año 2001, coleccionaba y conservaba en Berlín, y que fueron subastadas recientemente. Una de estas piezas es un casco de fina lámina de bronce con una decoración muy similar al de la colección Pérez Aguilar, pero con un perfil semiesférico aplanado, que según la descripción que aporta la casa de subastas, es resultado de la corrección de la deformación con que se halló. Deberemos esperar a su ingreso en el Museo Arqueológico Nacional para su valoración concreta y plantearnos las similitudes de esos cascos.

MAgDALENA BARRIL Vicente

Departamento de Protohistoria y Colonizaciones.

Museo Arqueológico Nacional, c/Serrano 13, 28001 Madrid; mbv@man.es

\section{BIBLIOGRAFIA}

ABÁsolo Álvarez, J. A.; PÉrez RodrígueZ, F. (1980): «El casco céltico de Gorrita (Valladolid)», Boletín del Seminario de Arte y Arqueología. Valladolid, Universidad, Facultad de Historia, 46: 103.

AIGNER FORESTI, L. (1992): «Relazioni protostoriche tra Italia ed Europa centrale», Parlavechia, P. (ed cient.): Gli Etruschi e l'Europa. Milano, Fabbri Editori, 1992: 158-167.

Aguilera y GamboA, E. (1912): «Nécropoles Ibériques», Congrés International d'Antropologie et d'Archeologie Prehistoriques. Géneve: 610-611, fig. 10. 
(1916): Las necrópolis ibéricas. Congreso de Valladolid. Madrid, Asociación Española para el Progreso de las Ciencias: $97 \mathrm{p}$.

Almagro-Gorbea, M. (1997): «Guerra y sociedad en la Hispania céltica», La Guerra en la Antigüedad. Una aproximación al origen de los ejércitos en Hispania. Madrid, Ministerio de Defensa, Comunidad de Madrid, 1997: 207-221.

Álvarez Gracia, A.; Cebolla Berlanga, J. L. y Blanco Morte, A. (1990): «Elementos metálicos de tipo celtibérico: La colección Pérez Aguilar», II Simposio sobre los celtíberos, Daroca 1988. Necrópolis celtibéricas. Zaragoza, Institución Fernando el Católico, 1990: 287-304.

ANTIKE Helme (1988): Antike Helme: Sammlung Lipperheide und Andere Bestände des Antiken museums Berlin, mit Beitragen von Angelo Bottini, Markus Egg, Friedrich-Wilhelm von Hase, Hermannn Pflug, Ulrich Schaaff, Peter Schauer, Götz Waurick. Mainz, Römisch-Gemanischen Zentral museums, 1988. (Monographien 14)

ARgente Oliver, J. L. (1972): Aportación al estudio e los materiales prehistóricos de la Necrópolis de Aguilar de Anguita en el Museo Arqueológico Nacional. Madrid, Universidad Complutense, Facultad de Filosofía y Letras. Memoria de licenciatura inédita.

BALLESTER, A. (1993): Análisis metalúrgico de fragmentos de casco ibérico. Informe mecanografiado con 19 figuras, gráficas y fotografías.

BAQUEDANO, I y CABRÉ, E. (1997): «Caudillos celtas y armamentos de parada» La Guerra en la Antigüedad. Una aproximación al origen de los ejércitos en Hispania. Madrid, Ministerio de Defensa, Comunidad de Madrid. 1997: 261-269.

BARRIL ViCENTE, M. (1996): «Imagen y articulaciones decorativas en la Meseta: los ejemplos de La Osera (Ávila)», Al otro lado del espejo. Aproximación a la imagen ibérica. Madrid, M. Picasso, 1996: 177-198. (Colección Lynx, 1)

(1997): «Abalorios celtibéricos de Almaluez (Soria)», Boletín del Museo Arqueológico Nacional, XV, 1 y 2. Madrid, 1997: 25-36.

(2002): «Fíbula (puente) de Drieves». Barril, M. - Rodero, A. (dir.): Torques, Belleza y Poder. Catálogo de la exposición. Madrid, Ministerio de Educación, Cultura y Deporte, 2002: 203.

BARRIL Vicente, M. y SAlve QueJido, V. (1998): «Reexcavando Aguilar de Anguita a través de los documentos escritos y los materiales depositados en el M.A.N.», Kalathos, 18. Teruel, 1998: 47-90.

(2000): «Formas de enterramiento y ritos funerarios en las necrópolis celtibéricas de Aguilar de Anguita (Guadalajara): El Altillo y La Carretera Vieja», Kalathos, 18-19. Teruel 1999-2000: 153-200.

BlÁzQuez Martínez, J. M. (1960): «Cascos celtas inéditos. Notas sobre los cascos hispánicos», Boletín de la Comisión de Monumentos de Orense, XX. Orense, 1959-69: 371-387.

BotHMER, D. von (coord.) (1979): Greek Art of the Aegean Islands. New York, The Metropolitan Museum of Art. 1979: 238 p.

Burillo Mozota, F. (1992): «Celtiberian Art», Joan Rosasco (ed.) Spain, A Heritage Rediscovered, 3000 BC-AD 711, New York, Ariadne Galleries; Meadows Museum, 1992: 63-95.

(1999): Segeda (Mara -Belmonte de Gracián). La ciudad celtibérica que cambió la historia. Zaragoza: Seminario de Arqueología y Etnología Turolense, 1999: 25 p.

CABRÉ Agulló, J. (1917): Catálogo monumental de la provincia de Soria, tomo III. Obra manuscrita.

(1940): «La Caetra y el Scutum en Hispania durante la Segunda Edad del Hierro», Boletín del Seminario de Estudios de Arte y Arqueología, VI. Valladolid,1939-1940: 5-83.

(1942): «El thymaterion de Calaceite», Archivo Español de Arqueología, 48. Madrid, 1942: 181-198. 
CABré de MorÁn, E. y MorÁn CABré, J. (1975): «Una decoración figurativa abstracta en la Edad del Hierro de la Meseta Oriental Hispánica», Congreso Nacional de Arqueología XIII. Huelva 1973. Zaragoza, 1975: 605-610.

CERDEÑO, M. L.; GARCIA HuERTA, R. (2001): «Las necrópolis celtibéricas: nuevas perspectivas de estudio», R. García Huerta y J. Morales Hervás (coor.) Arqueología funeraria: Las necrópolis de incineración. Cuenca, Universidad de Castilla-La Mancha, 2001: 141-190.

CERdeño, M. L.; SANMARtí, E. y GARCÍA-HuertA, R. (1999): «Las relaciones comerciales de los celtíberos», IV Simposio sobre celtíberos, Daroca 1997: Economía. Zaragoza, Institución Fernando el Católico: 263-299.

DeChelette, J. (1910-1913) Manuel d'Archéologie prehistorique, celtique et gallo-romaine. Paris, Picard, vol I-2, 1910 y v. II, 1913.

DíAz Martínez, S. (1997): Informe del Tratamiento de Restauración. Casco de Aguilar de Anguita. Broche de cinturón y Fragmentos. Madrid, Ministerio de Educación y Cultura, Instituto del Patrimonio Histórico Español. Texto mecanografiado.

Domingo Varona, L. (1981): Materiales de la necrópolis de «Almaluez» (Soria) conservados en el Museo Arqueológico Nacional. Madrid: Universidad Complutense. Memoria de licenciatura inédita.

(1982): «Los materiales de la necrópolis de Almaluez (Soria) conservados en el Museo Arqueológico Nacional», Trabajos de Prehistoria, 39. Madrid, 1982: 241-278.

EGG, M. (1988): «Die ältesten Helme der Hallstattzeit», Antike Helme. Berlin, 1988: 212-221.

Escudero NAVARRO, Z. (1990): «Las urnas de 'orejetas perforadas' en el mundo celtibérico» Numantia 3. Valladolid, 1990: 139-153.

FEUGÈre, M. (1994): Les casques antiques. Visages de la guerre de Mycènes à l'Antiquité tardive. Paris, Errance, 1994.

Galán Domingo, E. (1993): Estelas, Paisaje y Territorio en el Bronce Final del Suroeste de la Península Ibérica. Madrid: Universidad Complutense, 1993: 110 p. (Complutum Extra, 3).

GARCÍA Y BELlidO, A. (1993): España y los españoles hace dos mil años, según la Geografía de Strabón, edición Ma Paz García-Bellido. Madrid, Espasa Calpe, $1^{a}$ ed. 1943: 334 p. (Colección Austral Historia, 203).

García-Mauriño MuZQuiz, J. (1993): «Los cascos de tipo Montefortino en la Península Ibérica. Aportación al estudio del armamento de la II ${ }^{a}$ Edad del Hierro», Complutum 4. Madrid, 1993: 95-146.

Gracia Alonso, F. (2003): La guerra en la Protohistoria. Héroes, nobles, mercenarios y campesinos. Barcelona, Ariel, 2003: 324 p. (Ariel Prehistoria)

GUSI I JENER, F. (2001): «Distribución territorial y evolución cronocultural durante la Edad del Bronce en tierras de Castellón», Hernández Pérez, M.S. (coord): ...Y acumularon tesoros. Mil años de Historia en nuestras tierras. Alicante, Caja de Ahorros del Mediterráneo, 2001: 163-179.

HASE, F-W von (1988): «Früheisenzeitliche Kammhelme aus Italien», Antike Helme. Berlín, 1988: 195-211.

IZQUIERDO, P.; SolÍAs, J. M. (1991): «Dos cascos etruscos», en Remesal, J. - Musso, O. (coord): La presencia de material etrusco en la Península Ibérica (Barcelona 24-27 abril 1990). Barcelona, 1991: 601-614.

Jacobsthal, P. (1944): Early Cetic art. Oxford, Clarendon Pres, 2v. (reed. 1969).

KUKHAN, E. (1954): «Estatuilla de bronce de un guerrero a caballo del poblado ibérico de La Bastida de las Alcuses (Mogente, Valencia), Archivo de Prehistoria Levantina, V. Valencia, 1954: 147-158.

KunZE, E.; SCHLEIF, H. (1939): Bericht über Ausgrabungen in Olympia. T. III., VI, VII, 1938-1939. 
KunZE, E. (1961): Olympiabericht V11 (1961), 77-128.

KURTZ, W. S. (1991): «Elementos etrusco-itálicos en el armamento ibérico», en Remesal, J. Musso, O. (coord): La presencia de material etrusco en la Península Ibérica (Barcelona 24-27 abril 1990). Barcelona 1991: 187-195.

LORRIO, A. J. (1995): «La moneda hispánica, ciudad y territorio», Anejos de Archivo Español de Arqueología, XIV. Madrid, CSIC, 1995: 75-80.

(1997): Los celtíberos. Madrid, Universidad Complutense, Universidad de Alicante, 1997: 451 p. (Complutum Extra, 7).

Megaw, Ruth and Vincent (1989): Celtic art. From de beginnings to the Book of Kells. Toledo, Thames and Hudson, 1989: 288 p.

MÉLIDA, J. R. (1887): Historia del casco (Apuntes Arqueológicos), Madrid, Sucesores de Rivadeneyra, 51 p. Copia facsímil Valencia, Librerías Paris-Valencia, 1991.

Montero, I. y RovirA, S. (2001): «Estudios sobre metales arqueológicos quemados». En C. Roldán (ed.): IV Congreso Nacional de Arqueometría. Unidad de Arqueometría ICMUV. Valencia, 2001: 164-169.

Negueruela, I. (1990): Los monumentos escultóricos ibéricos del Cerrillo de Porcuna (Jaén). Estudio sobre su estructura interna, agrupamientos e interpretación. Madrid, Ministerio de Cultura, 1990.

Olmos Romera, R. (1988): «El casco griego de Huelva», Clásicos de la Arqueología de Huelva 1/1988. Huelva, Diputación, 1988: 37-78.

Pflug, H. (1988 a): «Korinthische Helme», Antike Helme. Berlín, 1988: 65-106.

(1988 b): «Italische Helme mit stirnkehle», Antike Helme. Berlín, 1988: 276-292.

Prados Torreira, L. (1992): Exvotos ibéricos de bronce del Museo Arqueológico Nacional. Madrid, Ministerio de Cultura, 1992: 385 p.

QUESADA SANZ, F. (1997): El armamento ibérico. Estudio tipológico, geográfico, funcional, social y simbólico de las armas en la Cultura Ibérica (siglos VI-I a.C.). Montagnac, Éditions Monique Mergoil, 2v. 1997. (Monographies Instrumentum 3).

(2002): «La evolución de la panoplia. Modos de combate y tácticas de los íberos», P. Moret y F. Quesada (eds.) La guerra en el mundo ibérico y celtibérico (ss.VI-II a. de C.). Madrid: Casa de Velázquez, 78, 2002: 35-64 (Collection de la Casa de Velázquez, 78).

(2003): «El casco corintio», La Aventura de la Historia, 53, 2003: 102-103.

ROMERo CARNICERO, F. (1976): Las cerámicas polícromas de Numancia. Valladolid, Patronato José María Quadrado, Centro de Estudios sorianos: 205 p. (Biblioteca Soriana).

RuIZ-GÁlvez PRIEGo, M. (ed.) (1996): Ritos de paso y puntos de paso. La Ría de Huelva en el mundo del Bronce Final Europeo. Madrid, Universidad Complutense, 1996: 250 p. (Complutum Extra, 5).

SANDARS, H. (1913): The Weapons of the Iberians, versión castellana Carlota Remfrey de Kidd. Oxford, University Press, 1913: 105 p.

SCHAAFF, U. (1988): «Keltische Helme», Antike Helme. Berlin, 1988: 293-317.

SCHAUER, P. (1988): «Die Kegal-und glockenförmigen Helme mit gegossenem scheitelknauf der Jüngeren Bronzezeit Alteuropas», Antike Helme. Berlín, 1988: 181-194.

SCHÜLE, W. (1969): Die Meseta-Kulturen der Iberischen Halbinsel. Berlín, Walter de Gruyter, 2 v. 1969 (Madrider Forstchungen, 3).

SNODGRASS, A. (1964): Early Greek armour and weapons. Edinburgh, University Press, 1964: 280, 37 p. con lám. 
STARY, P. F. (1981): Zur Eisenzeitlichen Bewaffnung und Kampefesweise in Mittelitalien (ca. 9 bis 6 Jh. V.Chr.), 2 v. Mainz am Rhein, Philip von Zabern, 1981.

(1982): «Keltische waffen auf der Iberischen Halbinsel», Madrider Mitteilungen 23. Berlin, 1982.

Taracena Aguirre, B. de (1932): «Excavaciones en la provincia de Soria. Campañas de 19031», Memorias de la Junta Superior de Excavaciones Arqueológicas, 119. Madrid, 1932.

(1933-1934): Diarios de las excavaciones de Almaluez. Texto manuscrito.

(1942): Carta arqueológica de la Provincia de Soria. Madrid, 1942.

Pallottino, M. (ed. cient.) (1992): «Schede. Relazioni protostoriche tra Italia ed Europa centrale», Gli Etruschi e l'Europa. Milano, Fabbri Editori, 1992: 248-254.

WATTENBERG, F. (1959): La región Vaccea. Celtiberismo y romanización en la cuenca media del Duero. Madrid, C.S.I.C., Instituto Español de Prehistoria, Diputación Provincial de Valladolid, 1959: 219 p, XIV lám. (Bibliotheca Praehistorica Hispana, II). 